ELIANE RODRIGUES BIO

\title{
Intervenção fisioterapêutica na assistência ao trabalho de parto
}

Dissertação apresentada à Faculdade de Medicina da Universidade de São Paulo para obtenção do título de Mestre em Ciências

Área de concentração: Obstetrícia e Ginecologia Orientador: Prof. Dr. Roberto Eduardo Bittar 


\section{Dados Internacionais de Catalogação na Publicação (CIP)}

Preparada pela Biblioteca da

Faculdade de Medicina da Universidade de São Paulo

Creprodução autorizada pelo autor

\section{Bio, Eliane Rodrigues}

Intervenção fisioterapêutica na assistência ao trabalho de parto / Eliane

Rodrigues Bio. -- São Paulo, 2007.

Dissertação(mestrado)--Faculdade de Medicina da Universidade de São Paulo. Departamento de Obstetrícia e Ginecologia.

Área de concentração: Obstetrícia e Ginecologia.

Orientador: Roberto Eduardo Bittar.

Descritores: 1.Trabalho de parto 2.Parto normal 3.Modalidades de fisioterapia 4.Comportamento materno 5.Ensaio clínico (tipo de publicação)

USP/FM/SBD-338/07 
A meu pai,

que me ensinou

que uma mulher precisa

ter independência intelectual.

A minha mãe,

que me mostrou que paciência e persistência são atributos essenciais para o feminino.

A meus filhos,

que ao iluminarem meu ventre e minha vida me fizeram uma pessoa melhor. 


\section{Ao Professor Doutor Marcelo Zugaib}

Digníssimo Professor Titular de Obstetrícia

do Departamento de Obstetrícia e Ginecologia

da Faculdade de Medicina da Universidade de São Paulo, meu profundo e sincero agradecimento pela confiança com que sempre acolheu meus projetos, por ter incentivado a semente desse estudo, pela oportunidade de concretização deste trabalho no seu serviço.

Ao Professor Doutor Roberto Eduardo Bittar exemplo de honestidade na conduta e na prática científica, minha imensa gratidão pelo interesse e disponibilidade em me orientar neste trabalho, pela condução segura em cada fase, pela presença amiga e afetuosa. 
Ao Professor Paulo Basto Albuquerque, agradeço pelo interesse na viabilização e acompanhamento da pesquisa e por ter me proporcionado, nos muitos plantões que fizemos juntos, as mais belas cenas de um obstetra competente, afetivo e respeitoso com o nascimento.

Agradeço a toda Equipe do Centro Obstétrico do Hospital Universitário, que com carinho me acolheu e introduziu os procedimentos da fisioterapia na sua rotina de assistência e que formam uma orquestra afinada entre médicos, enfermeiras e auxiliares, mantendo sempre a competência profissional, o bom humor e a leveza, necessárias em uma maternidade.

Fatimé, Cláudia e Camila, enfermeiras obstétricas experientes,dedicadas, cuidadoras sensíveis, especialmente pela cumplicidade e parceria, meu muito obrigada.

Ao Dr. Mário Macoto Kondo, Dr. Mário Henrique Burlacchini de Carvalho e Dr. Pedro Paulo Pereira, agradeço muito as preciosas sugestões na banca de qualificação.

À Dra. Rossana Pulcinelli Vieira Francisco, pela compreensão e sua particular contribuição para transformar minha experiência clínica em ciência, meu sincero agradecimento.

À Dra. Roseli Mieko Yamamoto, agradeço muito o interesse constante, o incentivo, a presença afetiva e ainda as preciosas sugestões.

À Maria Inês Dias Carvalho Lima, secretária competente e sempre presente, agradeço não só por resolver as formalidades essenciais, mas porque me ensinou "que os cães ladrem e a carruagem passa".

Ao Hélio Biesemeyer, por ajudar a olhar para minha trajetória pessoal e profissional e, em uma de nossas muitas conversas, me convencer a sistematizar minha experiência clínica, obrigada. 
Ao Fisioterapeuta Sérgio Mingrone, diretor da Faculdade de Fisioterapia da UNISA, pelo apoio na execução desse trabalho e pela confiança em mim depositada, sou muito grata.

Ao Dr. Wilson de Oliveira, agradeço pela presença sensível e amorosa, suporte em todas as etapas do processo.

À Célia, Júnia e Silvia Bio, irmãs queridas, agradeço pela parceria e pela presença imprescindível em cada etapa desse percurso e em todas as fases da minha vida.

Ao João Carlos Milanelli, agradeço por ter disponibilizado seu tempo e seu conhecimento para minha "iniciação" em bioestatística e pela presença afetiva com que acompanhou, conferiu e comemorou cada etapa realizada.

À Marcela Giotto Levi, não só pela competência profissional e inspiração na criação dos desenhos mas pelo carinho com que o fez, agradeço imensamente.

Ao Humberto, companheiro de toda essa jornada, desde o embrião desse projeto até os detalhes de sua finalização, minha alma reconhece agradecida sua paciência, seus "socorros", cuidados e mimos.

Agradeço a todas as pacientes que aceitaram que eu as ajudasse durante seu trabalho de parto e me possibilitaram presenciar junto com elas, o milagre do nascimento. 
"Muito da ciência é imaginação, é sonhar coisas que você ainda não tem." Mildred Spiewak Dresselhaus 
Esta dissertação está de acordo com as seguintes normas:

Referências: adaptado de Internacional Committee of Medical Journals Editors (Vancouver)

Universidade de São Paulo. Faculdade de Medicina. Serviço de Biblioteca e Documentação. Guia de apresentação de dissertações, teses e monografias. Elaborado por Anneliese Carneiro da Cunha, Maria Júlia de A. L. Freddi, Maria F. Crestana, Marinalva de Souza Aragão, Suely Campos Cardoso, Valéria Vilhena.. $2^{\mathrm{a}}$ ed. São Paulo: Serviço de Biblioteca e Documentação; 2005.

Abreviaturas dos títulos dos periódicos de acordo com List of Journals Indexed in Index Medicus. 
SUMÁRIO 


\section{SUMÁRIO}

Lista de tabelas

Lista de figuras

Lista de anexos

Resumo

Summary

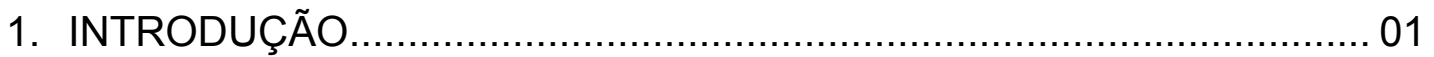

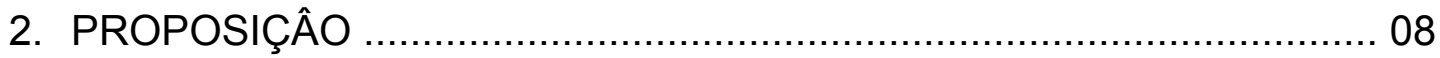

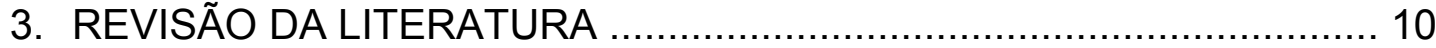

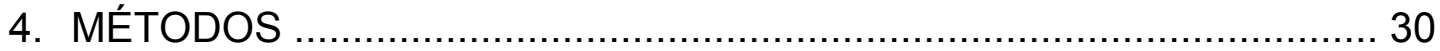

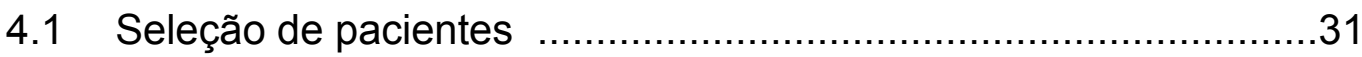

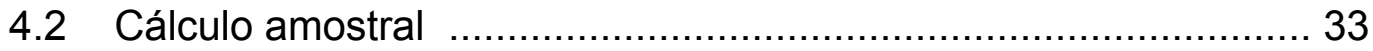

4.3 Caracterização da amostra f.................................................. 33

4.4 Acompanhamento das parturientes ..................................... 35

4.4.1 Mobilidade corporal f............................................... 37

4.4.1.1 Mobilidade corporal na insinuação fetal .......... 38

4.4.1.2 Mobilidade corporal na descida fetal ............. 44

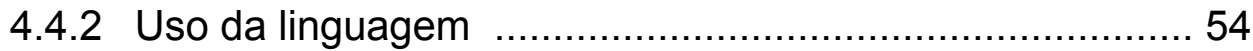

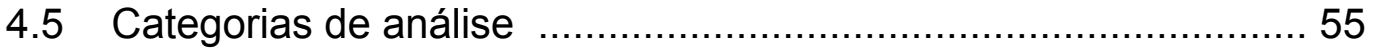

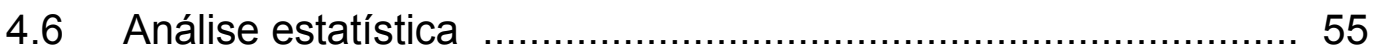




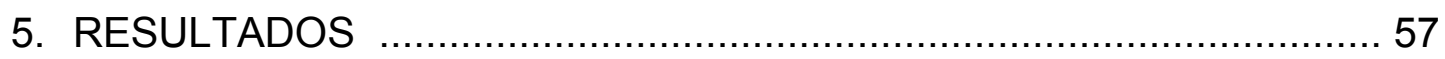

5.1 Caracterização das parturientes ..................................... 58

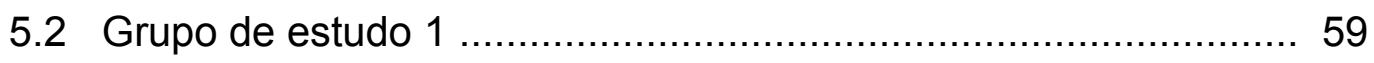

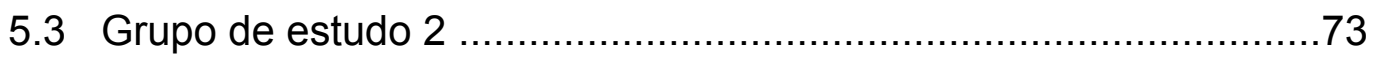

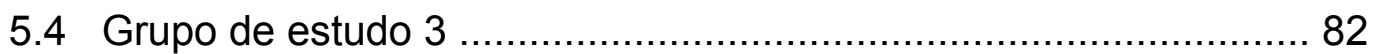

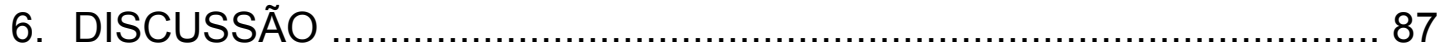

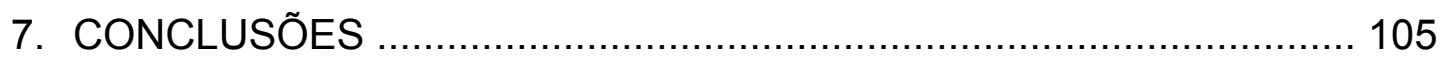

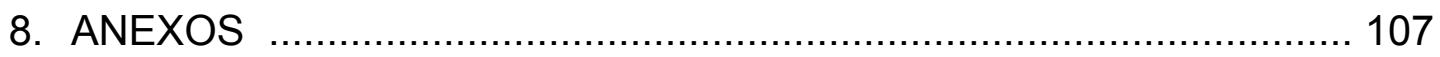

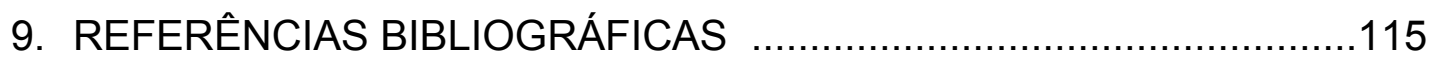




\section{LISTA DE TABELAS}

Tabela 1: Estatísticas descritivas das variáveis idade, idade gestacional... 35

Tabela 2: Descrição da homogeneidade dos grupos em relação às variáveis idade materna e idade gestacional.

Tabela 3: Peso dos recém-nascidos no grupo de estudo e no grupo controle

Tabela 4: Tipo de parto no grupo de estudo e no grupo controle 64

Tabela 5: Análise da duração da fase ativa e condição da bolsa das águas.

Tabela 6: Duração da fase ativa em relação ao esvaecimento do colo, separada por grupo.

Tabela 7: Comparação entre os grupos no uso da anestesia e fase da dilatação

Tabela 8: Índices de Apgar dos recém nascidos nos grupos de estudo e no controle

Tabela 9: Descrição da homogeneidade dos grupos em relação à idade e idade gestacional.

Tabela 10: Comparação entre os grupos em relação à duração da fase ativa.

Tabela 11: Comparação dos grupos em relação aos índices de Apgar. 83 


\section{LISTA DE FIGURAS}

Figura 1: Contra-nutação da pelve ……………………................... 40

Figura 2: Contra-nutação e insinuação ……………….......................... 40

Figura 3: Posições sentadas em contra-nutação e correção da lordose lombar

Figura 4: Posições sentadas com distensão dos adutores, inibição da rotação interna do quadril e inclinação do tronco

Figura 5: Posições em pé em contra-nutação, com correção da lordose lombar, verticalização do sacro, inclinação do tronco e leve flexão cervical

Figura 6: Distribuição do peso na cintura pélvica. …………………….... 42

Figura 7: Mobilização articular geral e mobilização pélvica. ...................... 42

Figura 8: Mobilização da articulação lombo-sacra e das vértebras lombares entre si

Figura 9: Mobilização das articulações sacro-ilíacas e coxofemurais. 43

Figura 10: Mobilização da pelve sobre a articulação coxofemural. 44

Figura 11: Nutação da pelve. 46

Figura 12: Posição fetal no estreito médio. 46

Figura 13: Relação do estreito médio da bacia e diafragma pélvico.

Figura 14: Posição sentada em nutação, na direção da descida fetal e abertura do espaço sacro-púbis.

Figura 15: Posição sentada em nutação, abdução e rotação externa; abertura do diâmetro biciático.

Figura 16: Posição em pé em nutação, abdução e rotação externa, inibição da contração do períneo.

Figura 17: Musculatura superficial do períneo. 49

Figura 18: Ação dos músculos do períneo nos diâmetros do estreito inferior. 
Figura 19: Posição de abertura do estreito inferior e relaxamento do períneo anterior.

Figura 20: Posição de cócoras e inibição da contração do períneo. ........... 50

Figura 21: Posição ajoelhada e abertura do estreito inferior da bacia. ..... 50

Figura 22: Posição em distensão de adutores, relaxamento do períneo e ampliação do diâmetro biisquiático.

Figura 23: Coordenação da respiração dinâmica.

Figura 24: Mobilização pélvica com abertura dos ísquios.

Figura 25: Seqüência de movimentos da parturiente ao longo do trabalho de parto.

Figura 26: Distribuição das parturientes segundo o tipo de parto e uso de ocitocina durante o trabalho de parto

Figura 27: Comparação entre o grupo de estudo e controle segundo as etnias no

Figura 28: Distribuição das parturientes segundo o grau de instrução nos grupos de estudo e controle

Figura 29: Distribuição das parturientes segundo o tipo de parto. 64

Figura 30: Representação gráfica da duração da fase ativa no grupo de estudo e controle 65

Figura 31: Classificação do colo uterino quanto ao grau de esvaecimento..67

Figura 32: Distribuição entre os grupos do uso de analgésicos. 69

Figura 33: Distribuição entre os grupos do uso de anestesia. 70

Figura 34: Comparação entre os grupos da distribuição das parturientes segundo as etnias.

Figura 35: Distribuição entre os grupos segundo o tipo de parto 76

Figura 36:Comparação entre os grupos do início da ocitocina em relação a fase da dilatação. 
Figura 37: Comparação entre os grupos do período com ocitocina.

Figura 38: Comparação entre os grupos em relação ao uso de anestesia.

Figura 39: Registro da progressão da dilatação, da dinâmica das contrações e da descida fetal, na fase ativa

Figura 40: Registro da progressão da dilatação, da dinâmica das contrações e da descida fetal, na fase ativa

Figura 41: Registro da progressão da dilatação, da dinâmica das contrações e da descida fetal, na fase ativa

Figura 42: Registro da progressão da dilatação, da dinâmica das contrações e da descida fetal, na fase ativa

Figura 43: Registro da progressão da dilatação, da dinâmica das contrações e da descida fetal, na fase ativa

Figura 44: Registro da progressão da dilatação, da dinâmica das contrações e da descida fetal, na fase ativa

Figura 45: Registro da progressão da dilatação, da dinâmica das contrações e da descida fetal, na fase ativa

Figura 46: Registro da progressão da dilatação, da dinâmica das contrações e da descida fetal, na fase ativa 86 


\section{LISTA DE ANEXOS}

Anexo A: Protocolo de pesquisa aprovado pela Comissão de Ética em Pesquisa do Hospital Universitário da USP (CEP-HU)

Anexo B: Protocolo de pesquisa aprovado pela Comissão de Ética para Análise de Projetos de Pesquisa do Hospital das Clínicas da Faculdade de Medicina da USP

Anexo C: Termo de Consentimento Livre e Esclarecido

Anexo D: Protocolo da avaliação fisioterapêutica 
RESUMO 
Bio ER. Intervenção fisioterapêutica na assistência ao trabalho de parto [dissertação]. São Paulo: Faculdade de Medicina, Universidade de São Paulo; 2007. 124p.

A assistência ao trabalho de parto envolve constante atualização sobre as intervenções obstétricas benéficas e necessárias para o nascimento seguro. Neste sentido, há uma redescoberta das posturas verticais e da liberdade de movimento da parturiente como prática eficiente para facilitar o trabalho de parto. Paralelamente, há uma tendência mundial à valorização do parto vaginal, a despeito das altas taxas de cesárea em nosso meio. Nesse contexto, se insere a proposta de intervenção fisioterapêutica na assistência ao trabalho de parto, com o objetivo de avaliar a influência da mobilidade da parturiente sobre a progressão da fase ativa, sobre a evolução da dilatação cervical e para facilitar o parto vaginal. Foi realizado um ensaio clínico controlado prospectivo, com análise comparativa entre um grupo de estudo e um grupo controle, no Centro Obstétrico do Hospital Universitário da Universidade de São Paulo. Os critérios de inclusão foram: primigestas em trabalho de parto espontâneo com pelo menos duas contrações a cada dez minutos e cérvico-dilatação de 3 a $4 \mathrm{~cm}$; idade gestacional entre 37 e 42 semanas; feto único em apresentação cefálica fletida e concordância em assinar o termo de consentimento livre e esclarecido. Foram excluídas parturientes com patologias clínicas. As parturientes foram acompanhadas pela mesma fisioterapeuta durante toda a fase ativa e orientadas a manterem-se em posições verticais e em movimento coordenado, principalmente a mobilidade pélvica.O grupo controle teve acompanhamento obstétrico sem a presença do fisioterapeuta e foi selecionado retrospectivamente, a partir dos registros de prontuário, com os mesmos critérios de inclusão e exclusão. A amostra estudada foi de 132 parturientes: 70 no grupo de estudo e 62 no grupo controle. No grupo de estudo, 62 parturientes $(89 \%)$ evoluíram para parto vaginal e oito $(11 \%)$ para cesárea. Entre as parturientes que evoluíram para parto vaginal, 50 o fizeram sem uso de ocitócico e a média de duração da fase ativa foi de $5 \mathrm{~h} 16 \mathrm{~min}$, enquanto que no grupo controle foi de $8 \mathrm{~h} 28 \mathrm{~min} \quad(p<0,001)$;nenhuma parturiente fez uso de analgésicos durante a fase ativa, ao passo que no grupo controle $62 \%$ das parturientes necessitaram de fármacos $(p<0,001)$; quanto a anestesia para o parto, nas parturientes do grupo de estudo $12 \%$ não fizeram uso de anestesia, $76 \%$ usaram anestesia entre 9 e $10 \mathrm{~cm}$ de dilatação; no controle, todas as parturientes usaram algum tipo de anestesia e $40 \%$ delas o fizeram entre 7 e $8 \mathrm{~cm}$ de dilatação $(p<0,001)$. As 12 parturientes que evoluíram para parto vaginal com uso de ocitocina durante a fase ativa, devido a hipoatividade uterina, tiveram, em média, $7 \mathrm{~h}$ de fase ativa e o controle, $11 \mathrm{~h}(p=0,059)$; o grupo de estudo iniciou mais tardiamente o uso de ocitocina e durante menos tempo $(p<0,05)$; nenhuma parturiente fez uso de analgésicos, enquanto que no controle $83 \%$ usaram fármacos para analgesia $(p<0,001)$. Concluiu-se que a ação na estrutura osteomuscular facilitou a progressão da fase ativa, a mobilidade pélvica promoveu a evolução da dilatação e o uso consciente do corpo favoreceu o parto vaginal. Descritores: trabalho de parto, parto normal, modalidades de fisioterapia, comportamento materno, ensaio clínico. 
Bio ER. Physiotherapy intervention during labor [dissertation]. São Paulo: "Faculdade de Medicina, Universidade de São Paulo"; 2007. 124p.

Obstetrics intervention during labor involves a continuous up date on childbirth safety. Thus, vertical positions and free movements of woman, have been rediscovered as an efficient practice, to make easy the evolution of labor. Parallelly, there is a worldwide opinion supporting natural childbirth, despite the high scores of cesarean section in our country. This is the argument of physiotherapy intervention during labor for evaluate the influence of the maternal mobility on the progression of the active phase of labor, on the evolution of cervical dilatation and to facilitate the vaginal delivery. A prospective clinical trial was conducted through comparative analysis among a treatment group and a control group, in the Obstetric Center of the Hospital Universitário da Universidade de São Paulo. The inclusion criteria were: primigravidae with spontaneous labor with two uterine contractions every ten minutes and 3 or $4 \mathrm{~cm}$ of cervical dilatation; with 37 to 42 weeks of pregnancy; with a single fetus on cephalic presentation, besides the agreement to sign the free and informed consent term. Patients with clinical affections were excluded. Patients were assisted by the same physiotherapist during the whole active phase and encouraged to stay in vertical positions and to move in coordenation and specially pelvic mobility. Control group had an obstetric support without the presence of the physiotherapist and it was selected retrospectively, according to the same inclusion and exclusion criteria. 132 primigravidae were accompained: 70 in the treatment group and 62 in the control group. In the treatment group, 62 $(89 \%)$ evolved to vaginal delivery and eight $(11 \%)$ evolved to cesarean section. Among the patients who evolved to vaginal delivery, 50 didn't use ocitocina and the mean of active phase was $5 \mathrm{~h} 16 \mathrm{~min}$, and in the control group the mean was $8 \mathrm{~h} 28 \mathrm{~min}(\mathrm{p}<0,001)$; none of the patients used analgesics during the active phase, but in the control group $62 \%$ of the patients needed farmacos $(p<0,001)$; as far as anesthesia for delivery is concearned, in the treatment group 12\% didn't use any, $76 \%$ used anesthesia between 9 and $10 \mathrm{~cm}$ of dilatation; in the control group, all the patients used some kind of anesthesia and $40 \%$ of them did it between 7 and $8 \mathrm{~cm}$ of dilatation $(p<0,001)$. The 12 patients who evolved to vaginal delivery with ocitocina during the active phase, due to an uterine hipoactivity, had a mean of $7 \mathrm{~h}$ duration active phase and the control group, $11 \mathrm{~h}$ $(p=0,059)$; the treatment group started later with the ocitocina and for a short period of time $(p<0,05)$; none of the patients used analgesics whereas in the control group $83 \%$ used farmacos for analgesia $(p<0,001)$. It follows that the intervention in the osteo and muscular structure facilited the progression of active phase, the pelvic mobility promoted the evolution of dilatation and the conscious use of the body improved the vaginal delivery.

Descriptors: labor, natural childbirth, physical therapy modalities, maternal behavior, clinical trial. 
1. INTRODUÇÃO 
A assistência ao trabalho de parto está sempre vinculada às representações sociais ligadas ao parto em cada cultura. Adapta-se às múltiplas condições socioeconômicas e transforma-se com as mudanças históricas.

Entre os partos domiciliares, assistidos por parteiras desde a antigüidade e os partos hospitalares da Obstetrícia atual, pode-se observar um grande panorama de transformações: o conhecimento sobre a fisiologia do parto ampliou-se, desfazendo mitos e orientando novos procedimentos; o avanço tecnológico introduziu exames complementares e equipamentos na assistência ao binômio materno-fetal, que podem monitorar e prevenir riscos; a analgesia e anestesia de parto incorporou- se à assistência, podendo gerar mais prazer e menos dor ao processo do nascimento; o parto foi institucionalizado e estabeleceu-se como procedimento médico. Além disso, a via de parto passou a ser muito questionada, a indicação de cesáreas eletivas e não-eletivas aumentou e a condição da mulher passou por mudanças significativas, vindas da compreensão de aspectos reprimidos da sexualidade feminina e da ampliação de seu papel social.

Dentro desse contexto, desde os anos 70, a assistência ao parto tem sido objeto de inúmeras condutas e motivo de controvérsias: discute-se sobre o que deve ser deixado à ordem do natural e o que significam intervenções obstétricas necessárias; que práticas do passado devem ser mantidas, baseadas em evidências e que outras devem ser 
Introdução

abandonadas; que tecnologias são apropriadas e respeitam a fisiologia feminina; que procedimentos estão baseados em efetividade e segurança; se o saber científico responde por todos os saberes e deve se sobrepor às crenças e à cultura de cada mulher; sobre o significado particular da vivência do parto e suas repercussões para a vida reprodutiva e sexual da mulher ${ }^{1,2}$.

Nessa contínua dialética entre o presente e o passado, entre o atual e o não-atual, entre o particular e o geral, é que a objetividade científica produz conhecimento num processo de atualização sempre em movimento ${ }^{3}$.

A proposta de atuação fisioterapêutica durante o trabalho de parto situa-se nesse contexto de conhecimentos novos, aplicados a práticas e comportamentos usuais das mulheres de gerações passadas.

É sabido que até o século XVIII, era comum entre as mulheres de praticamente todas as culturas, manter-se livremente em movimento durante o trabalho de parto, preferir posições verticais, não resistir à sensação das contrações, fazer uma respiração dirigida e ter maior aceitação da fisiologia do próprio corpo para o parto vaginal ${ }^{4}$.

Na perspectiva da fisiologia, o processo de trabalho de parto é natural para o organismo feminino e quando transcorre sem dificuldades, há necessidade de pouca intervenção, o que não significa que a parturiente não precise de acompanhamento.

O processo de trabalho de parto sempre necessitou de cuidados e de ajuda especial. A assistência institucional dos nossos dias, em grandes maternidades, profissionalizou o acompanhamento em procedimentos, 
muitas vezes organizados em função das necessidades das instituições, ao invés de centrados nas necessidades das parturientes ${ }^{5}$. A assistência ao parto vem exigindo um modelo tecno-assistencial que priorize a qualidade da atenção prestada, no que diz respeito à maneira indissociável do emprego das tecnologias, dos saberes, da centralidade do diálogo entre profissionais e pacientes e da escolha individualizada dos recursos considerados adequados para o nascimento seguro ${ }^{6}$.

A promoção da saúde materno-fetal envolve ultrapassar o modelo da atenção centrado apenas no monitoramento e controle do risco, em favor de procedimentos preventivos em direção à saúde ${ }^{7}$. Além disso, os significados que cada mulher atribui à experiência do nascimento não são menos importantes que a segurança materno-fetal, se o parto é entendido como evento biopsicossocial. Nesse sentido, a escolha de procedimentos que permitam a participação ativa da mulher pode favorecer a promoção da saúde, a proteção ao nascimento e os aspectos emocionais da parturição ${ }^{8}$

A Organização Mundial da Saúde propõe, desde 1996, a revisão das tecnologias apropriadas para o parto, preconizando a movimentação da parturiente durante a fase ativa, a mudança e livre escolha de posições durante as contrações e não ficar em posição supina durante o trabalho de parto 9 .

O Colégio Americano de Obstetras e Ginecologistas (ACOG) em Guideline de 2003, se refere a um conjunto de procedimentos clínicos usados no manejo ativo do trabalho de parto e entre as intervenções 
Introdução

baseadas em evidências, recomenda que a parturiente seja aconselhada a caminhar durante o trabalho de parto ${ }^{10}$.

Na França, em 2003, o Colégio Nacional dos Ginecologistas e Obstetras Franceses e a Agência Nacional de Avaliação da Saúde, propõem algumas recomendações clínicas aos profissionais sobre as práticas de assistência ao trabalho de parto. Entre elas, é tida como prática comprovadamente benéfica, manter a parturiente em movimento ${ }^{11}$.

No Brasil, o Programa de Humanização do Parto e Nascimento do Ministério da Saúde, lançado em junho/2000, formalizou e evidenciou iniciativas que já vinham ocorrendo, no sentido de se recuperar a participação mais ativa da parturiente em todo o processo do parto. Muitos serviços buscam implementar uma atenção à parturiente menos intervencionista, com práticas baseadas em evidências, menor uso de tecnologias, maior incentivo e ajuda para o parto vaginal ${ }^{12}$.

A preferência pelo parto vaginal ainda tem alta prevalência entre nós, a despeito das altas taxas de cesárea no Brasil e desta ter se tornado um bem de consumo, acessível às classes sociais favorecidas economicamente. Os estudos que analisam as expectativas das usuárias do sistema de saúde têm demonstrado claramente a busca pelo parto vaginal ${ }^{13,14,15}$.

Em todo o mundo têm ocorrido esforços, há pelo menos 30 anos, para tentar reintroduzir uma liberdade corporal durante o trabalho de parto, principalmente, quando o objetivo é facilitar o parto vaginal. As discussões de gênero pela autonomia e participação ativa da parturiente, bem como argumentos anatomofisiológicos, são convincentes, mas insuficientes para 
Introdução

mudança nas condutas de acompanhamento do trabalho de parto e do parto $^{16}$. As controvérsias se referem às discordâncias nos resultados dos estudos realizados. Os que defendem a movimentação da parturiente e as posturas verticais, atestam melhores resultados materno-fetais: menor duração do trabalho de parto, melhor manejo da dor, sensação da parturiente de controle do corpo e de si mesma, o que melhora a habilidade para lidar com o medo e com o manejo do processo de dilatação, contribuindo para a boa experiência e satisfação com o parto ${ }^{17,18}$. Os estudos que não recomendam as posições verticais e que discordam da efetividade em manter a parturiente em movimento, alegam que não é a movimentação e a verticalidade que facilitam a evolução da dinâmica uterina, mas sim, que nos trabalhos de parto de boa evolução, as parturientes preferem se movimentar e mesmo assim, só o fazem na fase inicial da dilatação, quando sentem menos dor ${ }^{19,20,21,22}$.

Em nosso meio não encontramos estudos que investiguem a eficácia de manter a parturiente em movimento. É verdade que há, em alguns serviços, orientações da enfermagem a favor da movimentação, estimulando a saída da parturiente do leito. Porém, não encontramos estudos em fisioterapia que demonstrem qual é a mobilidade materna funcional necessária para as exigências do trabalho de parto.

A presença do fisioterapeuta no acompanhamento do trabalho de parto não é uma prática estabelecida no nosso meio, tampouco incluída no sistema de saúde; as experiências são isoladas, com pacientes de clínica privada ou em maternidade-escola ${ }^{23}$. A atuação do fisioterapeuta tem 
sido, principalmente, dirigida ao período pré-natal, que envolve a preparação para o parto, mas não a presença do fisioterapeuta no acompanhamento da parturiente em centro obstétrico. Na Inglaterra, desde 1912, o fisioterapeuta atua tanto na preparação pré-natal como na assistência ao parto. Na França e Bélgica, há mais de 40 anos a fisioterapia é um dos recursos terapêuticos usados para a gestante e parturiente. Nos países nórdicos, os fisioterapeutas estão incluídos na equipe obstétrica ${ }^{24}$.

No Brasil, nesse tipo de assistência existe uma lacuna e conseqüente ausência de publicações e referências teóricas.

Este trabalho foi idealizado com o objetivo de avaliar se a intervenção fisioterapêutica melhora a evolução do trabalho de parto e facilita o parto vaginal. $\mathrm{O}$ estudo foi delineado para pesquisar a influência da mobilidade da parturiente e da estimulação sensório-motora dirigida, para potencializar a contração do miométrio e melhorar a cinética da dilatação, reduzindo o período de fase ativa.

Parte-se da hipótese que o corpo, nos seus aspectos objetivos e subjetivos, pode ser um instrumento ativo para facilitar o processo de trabalho de parto e o parto vaginal. 
O presente estudo, em parturientes submetidas à intervenção fisioterapêutica durante a fase ativa do trabalho de parto, teve como objetivo avaliar a influência da mobilidade da parturiente sobre:

1) a progressão do trabalho de parto

2) a evolução da dilatação cervical

3) o tipo de parto 
3. REVISÃO DE LITERATURA 
A literatura registra inúmeros trabalhos sobre as técnicas fisioterapêuticas que podem ser aplicadas na assistência ao trabalho de parto, as quais estão incluídas nos recursos não-farmacológicos utilizados no acompanhamento da parturiente. Mobilidade corporal e orientação da postura materna, são, entre outros, procedimentos fisioterapêuticos indicados durante o trabalho de parto.

A presente revisão se refere aos trabalhos que pesquisam os efeitos da mobilidade e da postura da parturiente na evolução do trabalho de parto, especialmente na dinâmica da atividade uterina e na duração da fase ativa.

Registros sobre a postura materna adotada no trabalho de parto são encontrados em sociedades primitivas, em culturas ocidentais e nãoocidentais. Até o final do século XVII, era habitual que as mulheres se mantivessem em movimento durante o trabalho de parto e principalmente, em posições verticais, isto é, de pé, andando, sentadas, de cócoras ou ajoelhadas. A posição da parturiente em decúbito dorsal, durante o trabalho de parto e no parto, não era comum na assistência obstétrica, antes do século XVIII ${ }^{4}$.

O obstetra francês François Mauriceau ${ }^{25}$ (1979), é tido como o introdutor do parto em posição ginecológica, em substituição à posição vertical usada anteriormente. A posição litotômica, instituída para facilitar as manobras obstétricas de assistência ao parto, introduziu-se na cultura ocidental e pouco a pouco, a postura ativa da parturiente, foi sendo 
substituída pela imobilização no leito, em decúbito horizontal ${ }^{26}$.

A partir dos estudos sobre a fisiologia da contração e as características da atividade uterina, realizados por Caldeyro-Barcia (1954) (apud Neme, 2005) ${ }^{27}$, foi possível demonstrar quantitativamente e não só na prática clínica, as influências da postura materna na evolução do trabalho de parto.

Em 1960, Caldeyro-Barcia et al. ${ }^{28}$, realizam no Uruguai, estudo com 84 mulheres em trabalho de parto espontâneo, para avaliar a influência da posição da parturiente no leito sobre a contratilidade uterina. As parturientes são orientadas a mudar da posição supina para o decúbito lateral direito ou esquerdo. A medida da pressão do líquido amniótico durante a contração mostra que o decúbito lateral diminui a freqüência e aumenta a intensidade das contrações; as contrações tornam-se mais coordenadas e o tônus uterino diminui; o efeito da mudança de posição é melhor nos trabalhos de parto espontâneos do que nas induções ou conduções com ocitocina. A metodologia que tais autores criaram, ou seja, a medida da pressão do líquido amniótico durante a contração uterina por meio de um cateter intra-útero conectado a um transdutor de pressão, foi reproduzida em muitos estudos nas décadas de 70 e $80^{29,30,31,32,33,34,35}$.

Os mais significativos dizem respeito a comparações entre posição horizontal e vertical durante o trabalho de parto e seu efeito na atividade uterina.

* Alvarez H. \& Caldeyro-Barcia R. Fisiologia de la contracción uterina y sus aplicaciones en la clínica. Mat. Infância. 13:11; 1954. 
Liu $^{29}$ (1974), nos Estados Unidos, pesquisa a atividade uterina em posição sentada com inclinação de $30^{\circ}$. Compara 60 primigestas em trabalho de parto: 30 em posição sentada e 30 em posição supina. Observa que na posição sentada a freqüência e a intensidade das contrações é maior, tornando o período de fase ativa duas horas mais curto em relação ao grupo que permanece em decúbito dorsal. Verificou também, maior relaxamento do tônus uterino entre as contrações, sem diferença nos índices de Apgar dos recém-nascidos nos dois grupos.

Arroyo et al. ${ }^{30}$ (1974), na Espanha , estudam o efeito da posição vertical sobre a contratilidade uterina, a dor da contração e a duração da fase ativa. Acompanham 20 parturientes de baixo-risco (18 nulíparas e 02 multíparas) em trabalho de parto espontâneo, a partir de $3-4 \mathrm{~cm}$ de dilatação, sem ocitocina e sem analgésicos. As mesmas foram orientadas a mudar, a cada 30 minutos, do decúbito dorsal para a posição vertical ( de pé, sentar e andar) e vice-versa. A contratilidade uterina foi maior nas posições verticais: a intensidade das contrações foi maior em 15 parturientes; a freqüência das contrações diminuiu em sete parturientes $(p<0,05)$. A duração da fase ativa foi de 6h20min nas nulíparas e 3h30min nas multíparas. As parturientes referiram menos dor nas posições verticais.

Mendez-Bauer et al. ${ }^{31}$ (1975), na Espanha, pesquisam a influência da posição de pé na atividade uterina. Em estudo randômico com 20 primigestas, mediram a intensidade e a freqüência das contrações em posição supina e em posição em pé, a partir dos $3 \mathrm{~cm}$ de dilatação. A intensidade das contrações aumentou na posição em pé, em 15 parturientes 
Revisão da Literatura

e permaneceu igual em quatro parturientes $(p<0,05)$. A frequência das contrações não se alterou na mudança de posição em 12 parturientes e aumentou na posição em pé, em oito parturientes. As irregularidades no ritmo e coordenação das contrações foram mais freqüentes na posição supina. Concluem que a atividade uterina aumenta significativamente na posição em pé.

Roberts et al. $^{32}$ (1983), em Chicago (EUA), comparam em 30 parturientes, o efeito da alternância de posição (a cada 30 minutos) na contratilidade uterina e na duração do trabalho de parto: 19 parturientes alternaram entre a posição sentada e o decúbito lateral e 11 entre a posição supina e o decúbito lateral. Observaram que a contratilidade uterina é mais eficiente e regular na posição sentada $(p<0,01)$, mas as parturientes preferiam ficar em decúbito lateral depois dos $6 \mathrm{~cm}$ de dilatação. No grupo que permaneceu em posição horizontal (decúbito dorsal ou lateral) a média de duração do trabalho de parto (entre 3 a $10 \mathrm{~cm}$ de dilatação) foi de 5 h24min e no grupo que alterna entre ficar sentada, até $6 \mathrm{~cm}$ e em seguida em decúbito lateral o período de fase ativa foi de $7 \mathrm{~h} 21 \mathrm{~min}$.

Outros autores investigam a atividade uterina, medindo a diferença da pressão intra-uterina sem contração, durante a contração e durante o esforço expulsivo, em posição vertical e em decúbito ${ }^{33,34,35}$.

Leeuw-Harmsen et al. ${ }^{33}$ (1983), na Finlândia, realizam estudo sobre a pressão intra-uterina de repouso na posição vertical, após a amniotomia artificial. Por meio de um micro sensor de pressão colocado intra-útero e na região retal, em 14 parturientes, registraram significativo aumento da 
pressão $(p<0,01)$, quando as parturientes ficaram em posição sentada ou de pé, sem contração. Concluíram que a posição vertical aumenta a pressão sobre o colo uterino, por fatores intra e extra-uterinos.

Mori et al. ${ }^{34}$ (1985), no Japão, medem a pressão do líquido amniótico com bolsa íntegra, em 99 mulheres em trabalho de parto espontâneo: 34 em posição sentada e 59 em posição supina. Nas parturientes que permaneceram sentadas, registrou-se diminuição da duração da contração uterina e aumento do tônus uterino de repouso $(p<0,05)$. Não observaram diferenças na duração da fase ativa entre os grupos.

Chen et al. $^{35}$ (1987), no Japão, realizam 116 registros de pressão intra-uterina em parturientes em posição supina e em posição sentada; observaram que a pressão intra-uterina durante a contração, não diferiu nas duas posições, mas também registraram que a intensidade da pressão do líquido amniótico, sem contração, era mais elevada na posição sentada $(p<0,05)$. Concluíram que a posição sentada favorece o tríplice gradiente descendente da contração uterina, a pressão do pólo cefálico sobre o colo uterino e conseqüentemente, o período expulsivo.

Nos estudos que utilizam como método o cateter intra-útero para medir a atividade uterina em relação à posição da parturiente, encontra-se apenas um que refere resultado negativo com a posição vertical.

Roberts et al. ${ }^{36}$ (1984), em Illinois (EUA), comparam a posição sentada com o de decúbito lateral (direito ou esquerdo) em 38 nulíparas, ao longo do processo de dilatação cervical. As parturientes foram orientadas a alternarem entre as duas posições a cada 30 minutos. Os resultados 
mostraram que, em decúbito lateral as contrações foram mais intensas, menos freqüentes e mais eficientes do que na posição sentada, principalmente com a dilatação mais avançada $(p<0,05)$. Isto também se dá, porque nesse grupo estudado, as parturientes preferiram a posição sentada no início da dilatação cervical e o decúbito lateral na progressão da fase ativa. Concluem que o decúbito lateral é comprovadamente eficiente e é alternativa eficaz quando a parturiente não deseja sentar.

Além dessas pesquisas, com ênfase principal na função do miométrio e na qualidade da contração uterina, estudos clínicos foram realizados com parturientes de diferentes culturas, demonstrando vantagens e desvantagens da movimentação da parturiente e da posição a ser adotada, na evolução do trabalho de parto ${ }^{37,38,39,40,41,42,43,44}$. Muitos desses estudos, descritos a seguir, são cronologicamente concomitantes aos anteriores, porém com metodologias diferentes. São ensaios clínicos controlados ou aleatorizados, sem uso de cateter intra-útero, e, portanto, com outros parâmetros de avaliação e análise.

Mitre $^{37}$ (1974), nos Estados Unidos, em estudo clínico randomizado, estuda a influência da posição materna na duração da fase ativa do trabalho de parto. Divide aleatoriamente 100 primigestas em dois grupos: 50 em posição sentada, com a possibilidade de se deitarem por algum período e outras 50 em posição supina, orientadas a mudar para o decúbito lateral; as que permaneceram sentadas, apresentaram a média de duração da fase ativa de 5 h47min (+/- 1,71); as que ficam em posição supina ou lateral a média de duração da fase ativa foi de 7h25min (+/- 1,64). O índice de Apgar 
dos recém-nascidos foi em média 9, nos dois grupos. Conclui que o período mais curto de trabalho de parto, em posição sentada, se deva ao aumento de pressão sobre a cérvice e a menor resistência que a gravidade impõe às contrações; o conforto e a tolerância à dor é maior entre as parturientes que permanecem sentadas.

Flynn et al. ${ }^{38}$ (1978), na Inglaterra, observam nulíparas e multíparas em deambulação e compararam com grupo controle em decúbito dorsal: 34 parturientes foram orientadas para a deambulação e 34 foram mantidas no leito. Os resultados mostram período de fase ativa duas horas mais curto no grupo da deambulação ( $p<0,001$ ); menos uso de ocitocina no grupo que deambula ( $p<0,05)$; quanto ao tipo de parto: no grupo que se manteve no leito, 22 partos vaginais, 10 partos fórcipes, 1 parto pélvico e 1 cesárea; no grupo da deambulação, 31 partos vaginais, 3 partos fórcipes $(p<0,01)$; menor demanda de analgesia (20 parturientes) em relação ao outro grupo onde todas as parturientes usaram analgesia $(p<0,001)$. Concluem que a deambulação deve ser encorajada no trabalho de parto.

Nesse período, dois estudos não encontram resultados positivos no uso das posições verticais durante o trabalho de parto ${ }^{39,40}$. McManus \& Calder $^{39}$ (1978), na Escócia, comparam 40 parturientes (nulíparas e multíparas) orientadas aleatoriamente, a permanecerem no leito ou assumirem a posição em pé. Williams et al. ${ }^{40}$ (1980), na Inglaterra, acompanham 103 parturientes (nulíparas e multíparas) divididas em: 55 em decúbito no leito e 48 andando ou sentadas. Ambos os estudos analisam os seguintes aspectos: freqüência da contração uterina, duração do trabalho de 
Revisão da Literatura

parto, uso de ocitocina, tipo de parto, alívio da dor, uso de anestesia e condições fetais. Não observaram vantagens nas posições verticais em nenhum desses aspectos. Além disso, referem que as parturientes preferem ficar deitadas, pois a posição vertical (andar e/ou sentar) é desconfortável. Entretanto, esses autores referem que não são encontrados efeitos danosos para mãe e feto nas posições verticais e, portanto, a mobilidade da parturiente não precisa ser desencorajada.

Diaz et al. ${ }^{41}$ (1980), comparam a evolução do trabalho de parto entre 145 parturientes em posição vertical e 224 em decúbito dorsal; ambos os grupos com nulíparas e multíparas, fetos em apresentação cefálica, com dilatação de até $5 \mathrm{~cm}$ no início do acompanhamento e bolsa íntegra. A duração da fase ativa foi 45 minutos mais curta no grupo em posição vertical $(p<0,05)$; na comparação entre as nulíparas, a diferença de duração da fase ativa foi de $2 \mathrm{~h} 27$ min mais curta no grupo que permaneceu em posições verticais $(p<0,001)$. A incidência de aplicação de fórcipe foi maior no grupo que permanece em decúbito dorsal $(p<0,05)$; a posição vertical não alterou a rotura oportuna das membranas. Concluem que a posição vertical facilita a dilatação, por favorecer o ângulo entre o eixo do pólo cefálico e os diâmetros da pelve, sem prejuízo ou dano perinatal.

Em estudo clínico randomizado, Read et al. ${ }^{42}$ (1981), na Califórnia (EUA), pesquisam o efeito da deambulação para acelerar a atividade uterina, em trabalhos de parto lentos. Estudaram 14 mulheres (primíparas e multíparas), todas com bolsa rota, com contrações irregulares e evolução lenta da dilatação; oito delas permaneceram em deambulação e seis ficaram 
Revisão da Literatura

no leito com infusão de ocitocina para condução das contrações. Os resultados mostraram melhora na evolução da fase ativa, naquelas que permanecem andando $(p<0,05)$. Concluíram que nesse grupo, a deambulação foi tão efetiva quanto a ocitocina na condução das contrações para evolução da dilatação.

Ainda quanto a indicação da deambulação para melhorar a evolução da dilatação, Hemminki et al. $^{43}$ (1985), na Finlândia, realizam estudo randômico com 57 parturientes em fase ativa protraída. As parturientes foram estimuladas a andar e o fizeram se desejassem. Entre elas, 30 permaneceram andando e nas demais $(n=27)$ foi prescrito ocitócico para condução das contrações. Na comparação dos resultados, houve diferença significante na aceleração das contrações depois dos $6 \mathrm{~cm}$, no grupo que deambulou $(p<0,001)$ e o período expulsivo foi mais rápido. No grupo com ocitocina, as contrações foram relatadas como muito intensas e houve maior necessidade de analgesia $(p<0,05)$. Concluem que a deambulação é eficiente como tratamento para fase ativa protraída.

Em estudo de revisão, Lupe \& Gross $^{44}$ (1986), avaliam seis estudos clínicos randomizados sobre postura e mobilidade materna durante o trabalho de parto. Selecionaram pesquisas com resultados a favor e contra, as posições verticais e deambulação durante a fase ativa. Concluíram que, dada a controvérsia nos resultados, não foi possível comprovar a real efetividade das posições verticais e deambulação, como técnica que favorece a evolução do trabalho de parto. Entretanto, na década de 90 , os estudos clínicos sobre mobilidade da parturiente e posturas durante 0 
Revisão da Literatura

trabalho de parto, continuam sendo tema recorrente de pesquisa na literatura científica ${ }^{45,46,26,47,48,49,50,51,52}$.

Andrews \& Chrzanowski $^{45}$ (1990), em Cleveland (EUA), avaliam durante a fase ativa, 40 nulíparas de baixo risco, com gestação a termo e membranas íntegras. Compararam um grupo de 20 parturientes em posição vertical com outro $(n=20)$ em decúbito horizontal (decúbito lateral direito ou esquerdo, alternando com decúbito dorsal). No grupo que se manteve em posição vertical, a aceleração das contrações foi mais rápida, quando comparadas às que permaneceram no leito em decúbito $(p=0,003)$. Concluem que as parturientes devem ser auxiliadas a utilizar posturas verticais, pois diminui o período de fase ativa, não aumenta o desconforto materno e não causa efeitos adversos no feto.

Melzack et al. ${ }^{46}$ (1991), em Quebec (Canadá), medem a dor lombar e dor no baixo ventre nas posições verticais e horizontais de acordo com a evolução da dilatação. Acompanham 60 parturientes, com dilatação entre $2 \mathrm{~cm}$ até $5 \mathrm{~cm}$, alternando posição supina ou decúbito lateral com posição em pé ou sentada até o final do trabalho de parto. A partir da aplicação da escala analógica de dor, registraram que: até os $5 \mathrm{~cm}, 47,5 \%$ das parturientes referem menos dor, tanto lombar quanto no baixo frente, nas posições verticais $(p<0,05)$. Depois dos $6 \mathrm{~cm}$ as parturientes preferiram a posição horizontal, porém sentiram mais dor e solicitaram anestesia $(p<0,05)$.

Em extensa revisão da literatura, em 1991, Johnson et al. ${ }^{26}$ selecionam, oito posições usadas durante o trabalho de parto: decúbito 
Revisão da Literatura

lateral, posição supina, posição de Trendelenburg, deambulação, posição sentada, posição ajoelhada, quatro apoios e cócoras. A avaliação dos resultados encontrados nos estudos, revelou que a contração uterina é mais intensa e mais freqüente com a parturiente em posição vertical do que em posição supina; na atividade uterina incoordenada, a deambulação produz resposta positiva imediata e é tão eficaz quanto ocitocina; a descida do pólo cefálico é favorecida pela mobilidade da parturiente, especialmente o movimento da pelve.

MacLennan et al. ${ }^{47}$ (1994), na Austrália, pesquisam se a deambulação durante o trabalho de parto, oferece mais vantagens ou desvantagens. Avaliaram 196 mulheres em trabalho de parto: 96 em deambulação e 100 em decúbito dorsal e compararam a duração da fase ativa, uso de analgesia, tipo de parto e satisfação materna. Nesses parâmetros avaliados, só observaram significativa vantagem na redução do uso de analgesia, no grupo que se manteve deambulando.

A partir de 1996, a Organização Mundial da Saúde ${ }^{48}$, preconiza entre as práticas eficientes para melhorar a evolução do trabalho de parto, as posições verticais, liberdade para a parturiente se movimentar e não ficar em posição supina.

Albers et al. ${ }^{49}$ (1997), examinam 1678 mulheres, em três serviços do México, que usam a deambulação como primeira intervenção para facilitar o trabalho de parto. A incidência de parto cesárea, é menor entre as parturientes que optam por não usar analgesia peridural e mantem-se em movimento e andando, do que entre as que não se movimentam. 
Na década de 90, encontra-se um único estudo que discute que as posturas verticais, não trazem benefícios para parturiente. Bloom et al. ${ }^{50}$ (1998), no Texas (EUA) em estudo randômico, pesquisam o efeito do caminhar durante o trabalho de parto. Acompanharam 1067 parturientes durante a fase ativa: 536 orientadas a caminhar e 531 a permanecerem no leito. Não encontraram diferenças significantes entre os grupos na duração da fase ativa, no uso de ocitocina e de analgesia ( $p=0,65)$. Concluem que caminhar durante o trabalho de parto não acelera a evolução da fase ativa, mas não é nocivo nem para a mãe e nem para o feto.

Nesta fase do debate científico sobre a posição materna durante o trabalho de parto, os estudos clínicos, trabalhos de revisão e metanálises tentam definir se há justificativa para incentivar a liberdade de movimento da parturiente, se tal pode ser prejudicial para a evolução do trabalho de parto e para o feto, se as posições verticais podem ser úteis quando a evolução da dilatação é muito lenta ou se aumentam o edema ou causam danos perineais, se podem ser usadas nos trabalhos de parto distócicos, se a mobilidade pode contribuir para diminuir a incidência do parto cesárea ${ }^{51}$.

Kelly et al. ${ }^{52}$ (1999), realizam revisão da literatura sobre posições para o trabalho de parto e parto. Analisam vantagens e desvantagens, da posição supina, do decúbito lateral, da posição de cócoras, do sentar e da posição de quatro-apoios em 26 estudos. A posição supina e o decúbito lateral esquerdo são excelentes para os procedimentos obstétricos, porém manter a parturiente no leito em posição supina associa-se a trabalhos de parto mais longos e a maior incidência e persistência da apresentação occipto- 
posterior; o decúbito lateral esquerdo é menos nocivo nesse sentido, oferece conforto à parturiente mas também está associado a fase ativa mais longa. As posições verticais, sentada, ajoelhada, de cócoras e em quatro-apoios trazem vantagens em relação às posições horizontais, pois tornam as contrações mais eficientes, diminuem o período de fase ativa e aliviam a dor, porém, a posição sentada pode diminuir o diâmetro pélvico, dependendo da inclinação do tronco e pode aumentar o edema no períneo; a posição de cócoras aumenta o diâmetro sagital e o diâmetro biciático entre 0,5 até $2 \mathrm{~cm}$, porém pode ser muito desconfortável pelo aumento da pressão perineal, apesar do edema da vulva ser semelhante ao da posição supina. A posição de cócoras e de quatro apoios são culturalmente de difícil aceitação no Ocidente, entre médicos e pacientes, apesar da posição de quatroapoios estar associada a menor dano perineal, aumento dos diâmetros pélvicos e facilidade de mobilização. Concluem que um bom resultado da posição ou posições escolhidas pela parturiente é: mínima dor, máxima independência da mulher, mínimo de anestesia, mínimo risco e dano para o períneo e máximas condições de vitalidade fetal, o que não se encontra em uma única posição, mas na mudança postural ao longo do trabalho de parto.

Nos anos 90 em diante, a "medicina baseada em evidência" torna-se o novo paradigma na seleção e aplicação das práticas clínicas, questionando efetividade, eficácia e segurança. Baseado nesse princípio, Rooks $^{53}(1999)$, realiza estudo de revisão sobre condutas de rotina na assistência ao trabalho de parto, classificando muitas delas como "práticas baseadas em evidências", por serem seguras e eficazes. A movimentação 
da parturiente e as posições verticais, oferecem, com clara evidência, mais benefícios para parturientes de baixo risco.

Gupta \& Nikodem ${ }^{54}$ (2000), examinam historicamente, os tradicionais hábitos das parturientes nas culturas ocidentais. Observam que no Ocidente o trabalho de parto é abordado primariamente, em termos de atividade uterina e não da atividade corporal da parturiente. Nos trabalhos que defendem que as parturientes se mantenham ativas e em posições verticais, as vantagens relatadas, pesquisadas e estudadas são: o efeito da gravidade é sinérgico com a direção da contração sobre a cérvice, menor compressão da veia cava e da aorta, melhora do equlíbrio ácido-básico do recém-nascido, contrações uterinas mais eficientes, melhora do alinhamento do feto na passagem pela pelve, evidência radiológica de aumento dos diâmetros pélvicos (transverso e antero-posterior) na posição de cócoras e ajoelhada.

Walsh $^{55}$ (2000), em metanálise, compara sete trabalhos sobre deambulação e mobilidade da parturiente. Resume os méritos da mobilidade e da posição vertical: melhora a atividade uterina, encurta o período de fase ativa, diminui a indicação de ocitocina, diminui a necessidade de analgesia e fármacos durante o trabalho de parto, facilita o parto vaginal, reduz as cesáreas e diminui o stress fetal. Conclui seu estudo com algumas recomendações práticas: a mobilidade da parturiente deve ser encorajada; as mulheres devem ser informadas das vantagens das posturas verticais e das desvantagens da posição supina; deve ser providenciado apoio para a parturiente ficar nas posições verticais; as mulheres devem ser informadas 
que algumas intervenções, como a peridural, podem dificultar a mobilidade; as posições devem ser introduzidas na preparação pré-natal.

Vallejo et al. ${ }^{56}(2001)$, em estudo randômico prospectivo, acompanham 151 nulíparas em dois grupos: 75 permaneceram em posição vertical (andando ou sentadas em cadeira) e 76 em decúbito no leito. Ambos os grupos receberam a mesma dose de analgesia peridural, entre 3 a $5 \mathrm{~cm}$ de dilatação. Os autores não registraram diferenças significativas entre os grupos, quanto à duração da fase ativa e tipo de parto. Concluíram que a posição vertical não acelera a fase ativa mesmo com analgesia da dor.

Entretanto, Simkin \& O’Hara ${ }^{57}$ (2002), em revisão sistemática, incluem movimento e posição vertical entre os métodos não-farmacológicos para alívio da dor no trabalho de parto.

Adachi et al. $^{58}$ (2003) estudam o alívio da dor, em 58 parturientes japonesas (39 primíparas e 19 multíparas) orientando-as a alternar entre a posição sentada e a posição supina, a cada 15 minutos, até $8 \mathrm{~cm}$ de dilatação. Os índices de dor medidos pela escala analógica, são significativamente menores na posição sentada do que em posição supina $(p<0,001)$

Bodner-Adler et al. ${ }^{59}$ (2003), em Viena, comparam 307 parturientes mantidas em posição vertical com outras 307 em posição supina, durante a fase ativa. Naquelas que permaneceram em posições verticais, houve uma diferença significante no uso de analgesia $(p=0,0001)$ revelando, portanto, menos dor; houve também menor necessidade de ocitocina $(p=0,001)$. 
Revisão da Literatura

Na França, em 2003, Maria et al. ${ }^{11}$, numa discussão sobre a assistência obstétrica baseada em evidências e a excessiva medicalização do parto, salientam a importância de se respeitar a fisiologia do trabalho de parto e a dimensão emocional do nascimento no uso das tecnologias modernas. Salientam que, manter a parturiente em movimento é prática tida como comprovadamente benéfica, mesmo que ainda necessite de estudos controlados para demonstrar sua eficácia.

Em 2003, o American College of Obstetricians and Gynecologists ${ }^{60}$ recomenda a deambulação ou a movimentação de livre escolha da parturiente, como um dos procedimentos eficientes para melhorar o conforto e manejo da dor pela parturiente, principalmente em trabalhos de parto distócicos. Salientam que, se a mobilidade da parturiente não acelerar o progresso do trabalho de parto, não oferece risco materno-fetal.

Frenea et al. ${ }^{61}$ (2004), na França, estudam o efeito da deambulação combinada com baixa dose de infusão de peridural, na duração do trabalho de parto e na sensação de dor. Comparam 30 parturientes em deambulação com 31 parturientes em decúbito. Não encontraram diferenças significativas na duração da fase ativa e nem nos escores da escala visual analógica de dor $(p=0,7)$. Entretanto, o grupo que permanece andando precisa de dose menor de bupivacaína, do que as que se mantém no leito $(p=0,01)$. O grupo da deambulação, também usa menos ocitocina, do que o que fica em decúbito $(p<0,05)$. Concluem que, mesmo não havendo diferença significante entre os grupos, na duração da fase ativa e no alívio da dor, os resultados revelam que a deambulação traz vantagens para a evolução do trabalho de parto. 
Em 2004, Roberts et al. ${ }^{62}$ realizam uma revisão sistemática sobre o impacto das posições verticais combinada com a administração de baixa dose de analgesia peridural, sobre a fase ativa o tipo de parto. Analisam cinco estudos randômicos (1161 mulheres). Não encontram diferenças significantes no tipo de parto e duração do período de dilatação, mas observam que não inibir a motricidade da parturiente para andar e se movimentar livremente durante a fase ativa do trabalho de parto, traz mais satisfação e conforto para a parturiente; não registram efeitos adversos da deambulação nem para mãe nem para o feto.

Simkin \& Bolding ${ }^{63}$ (2004), estudam 13 técnicas não-farmacológicas para manejo da dor durante o trabalho de parto. Entre outras, a mobilidade e o posicionamento da parturiente mostram-se como procedimentos adequados e benéficos na assistência ao trabalho de parto.

Lugina et al. ${ }^{64}$ (2004), realizam estudo quantitativo e qualitativo em quatro hospitais públicos na Tanzânia. A rotina dessas maternidades no acompanhamento do trabalho de parto mantém as parturientes no leito. Verificam por meio de entrevistas com as parturientes e com a equipe obstétrica, que existem enormes barreiras para mudar o costume das mulheres de permanecerem imóveis no leito, durante o trabalho de parto e também da equipe profissional para orientar e encorajar a mobilidade da parturiente.

Cunningham et al. ${ }^{65}$ (2005), referem que mesmo não havendo consenso na eficácia da posição vertical, os estudos não demonstram qualquer contra-indicação e portanto, concorda-se que as parturientes de 
Revisão da Literatura

baixo-risco escolham livremente a posição mais confortável. Em trabalhos de parto com evolução lenta da dilatação, recomendam a deambulação.

Racinet $^{16}$ (2005), chama a atenção para a redescoberta das posturas verticais usadas universalmente e historicamente no trabalho de parto. Salienta a evidente superioridade das posturas verticais e da importância da parturiente em movimento, sobre todos os parâmetros do trabalho de parto e da saúde perinatal da mãe e do concepto. Além de não comprometer o uso da monitoragem fetal e dos outros procedimentos obstétricos necessários, nas posturas verticais o efeito da gravidade sobre o feto fica em sinergia com a direção da contração uterina; as posturas verticais não têm efeito compressivo sobre a veia cava inferior e sobre a aorta, ao contrário da posição supina; melhoram a ventilação pulmonar, principalmente dos lobos inferiores; facilitam a excursão diafragmática; melhoram e ampliam as dimensões pélvicas; melhoram a dor da contração e diminuem o uso ou a dose de anestesia.

Entre nós, Cecatti e Calderón ${ }^{66}$ (2005), realizam trabalho de revisão sobre intervenções benéficas durante o trabalho de parto. Enfocam as evidências derivadas de estudos com rigor metodológico e ensaios controlados randomizados, sobre intervenções capazes de reduzir complicações e morbidade materna. Entre as principais intervenções, a movimentação da parturiente durante o período de dilatação, é considerada eficiente para melhorar a contração uterina, reduzir o período de fase ativa, diminuir o uso de analgésicos e de anestesia e gerar mais conforto. 
Revisão da Literatura

$\mathrm{Neme}^{26}$ (2006), cita entre as condutas de assistência obstétrica no pré-parto, a orientação da postura da parturiente em decúbito lateral esquerdo ou em deambulação, para melhorar a coordenação miometrial elevando a atividade uterina. Recomenda a deambulação até os $8 \mathrm{~cm}$ da cérvico-dilatação e enquanto as membranas estiverem íntegras.

A revisão cronológica das publicações aqui realizada, desenha as muitas e variadas facetas exploradas pelos pesquisadores, sobre a influência da mobilidade e da postura materna no trabalho de parto.

A diversidade de resultados indica que ainda existem controvérsias quanto ao objetivo de manter a parturiente em movimento apesar de a maioria dos autores ser favorável a uma atitude ativa da parturiente.

A posição e a mobilidade materna durante o trabalho de parto, que sempre foram comportamentos usuais e intuitivos, tornam-se agora, objeto de discussão científica, para validar sua aplicação e efetividade. 
O estudo realizado foi um ensaio clínico controlado, prospectivo, com análise comparativa entre um grupo de estudo e um grupo controle.

A população estudada foi de primigestas, admitidas no pré-parto da Divisão da Clínica Obstétrica do Hospital Universitário da Universidade de São Paulo, no período compreendido entre maio/2003 a novembro/2005.

O protocolo de pesquisa foi aprovado pela Comissão de Ética em Pesquisa do Hospital Universitário (CEP-HU) e pela Comissão de Ética para Análise de Projetos de Pesquisa do Hospital das Clínicas da Faculdade de Medicina da USP (CAPPesq), conforme anexos A e B.

As parturientes foram convidadas a participar do estudo e todas assinaram o Termo de Consentimento Livre e Esclarecido (Anexo C).

\subsection{Seleção das pacientes}

As parturientes selecionadas foram divididas em dois grupos: um grupo de estudo, composto por aquelas acompanhadas e um grupo controle.

No grupo de estudo, as parturientes foram selecionadas após avaliação obstétrica e admissão no Centro Obstétrico.

O grupo controle foi composto por parturientes que tiveram acompanhamento obstétrico, sem a presença da fisioterapeuta. Este grupo foi selecionado, a partir dos registros de admissão no mesmo período em que foi realizado o estudo. O primeiro critério de busca foi o tipo de parto, 
isto é, só mulheres com parto vaginal foram selecionadas; em seguida foram preenchidos os critérios de inclusão descritos a seguir.

Tanto o grupo de estudo como o grupo controle obedeceram aos mesmos critérios de inclusão e de exclusão estabelecidos.

\subsubsection{Critérios de inclusão}

Foram incluídas no estudo as parturientes que atenderam aos seguintes critérios:

a) primigestas em trabalho de parto espontâneo, com dinâmica uterina de pelo menos duas contrações uterinas a cada dez minutos e cérvicodilatação de 3 a $4 \mathrm{~cm}$.

b) idade gestacional de 37 a 42 semanas, confirmada por pelo menos duas ultra-sonografias compatíveis até a $20^{a}$ semana de gestação.

c) feto único em apresentação cefálica fletida.

d) concordância em assinar o "Termo de Consentimento Livre e Esclarecido"

\subsubsection{Critério de exclusão}

Foram excluídas da amostra:

a) parturientes com patologias clínicas associadas a gravidez.

b) parturientes com intercorrências obstétricas 


\subsection{Cálculo amostral}

A estimativa do tamanho da amostra $(n)$ foi feita visando a comparação de duas médias, sendo as variáveis de interesse quantitativas ${ }^{67}$. 0 objetivo foi comparar as médias de duas populações distintas, para demonstrar diferenças entre o grupo de estudo e o grupo controle em relação à intervenção fisioterapêutica.

O tamanho da amostra calculada foi de 50 parturientes para cada grupo, para um poder de teste de $80 \%$ e nível de significância de $5 \%$. Teste de hipótese bicaudal.

\subsection{Caracterização da amostra}

A população estudada foi caracterizada pelo tipo de parto, idade gestacional, faixa etária, cor e escolaridade.

$\mathrm{Na}$ composição dos grupos de estudo e controle, foram consideradas variáveis dependentes: tipo de parto, idade gestacional e idade materna. As variáveis independentes foram: cor e escolaridade. O nível socioeconômico da população atendida no Hospital Universitário é médio e baixo.

A amostra estudada caracterizou-se por 70 parturientes no grupo de estudo, das quais 62 tiveram parto vaginal e oito parturientes que evoluíram para cesárea. O grupo controle foi composto por 62 parturientes com parto vaginal. 


\subsubsection{Grupo de Estudo}

A caracterização das 70 parturientes acompanhadas foi:

$\left.1^{\circ}\right)$ média de idade de 21,99 anos (+/-4,83), mínima de 15 anos e máxima de 37 anos.

$2^{\circ}$ ) mediana da idade gestacional de 39 semanas.

$\left.3^{\circ}\right)$ distribuição racial diversa: a maioria de cor branca $(67,1 \%)$, um número menor de cor parda $(25,7 \%)$ e poucas de cor negra $(7,1 \%)$.

$4^{\circ}$ ) nível de escolaridade variável: não houve analfabetas, $40 \%$ com grau de instrução elementar ( $28,6 \%$ com ensino básico incompleto; $11,4 \%$ somente com ensino básico completo); as demais $60 \%$, apresentaram grau de instrução maior $(38,6 \%$ com ensino fundamental completo $14,2 \%$ com ensino fundamental incompleto, $4,3 \%$ com nível técnico e 2,9\% com nível superior).

\subsubsection{Grupo Controle}

O grupo controle selecionado caracterizou-se por:

$\left.1^{\circ}\right)$ média de idade de 20,81anos ( +/- 4,08 ), mínima de 15 anos e máxima de 35 anos

$\left.2^{\circ}\right)$ mediana da idade gestacional de 39 semanas ( +/- 1.02$)$.

$\left.3^{\circ}\right)$ distribuição racial: a maioria de cor branca $(63,9 \%)$, um número menor de cor parda $(30,6 \%)$ e poucas de cor negra $(6,6 \%)$.

$4^{\circ}$ ) nível de escolaridade variável: não houve analfabetas, 41,9\% com grau de instrução elementar (17,7\% com ensino básico incompleto; 24,2\% 
somente com ensino básico completo); as demais 58,1\%, apresentaram grau de instrução maior (35,5\% com ensino fundamental completo, $21 \%$ com ensino fundamental incompleto e 1,6\% com nível superior). .

A tabela 1, a seguir mostra a caracterização da amostra em relação às variáveis dependentes, idade e idade gestacional. A comparação entre o grupo de estudo e o grupo controle, demonstram que os mesmos foram homogêneos e, portanto, comparáveis.

Tabela 1: Estatísticas descritivas das variáveis idade e idade gestacional.

\begin{tabular}{clcccccc}
\hline \hline \multirow{2}{*}{ Grupo } & N & Média & Mediana & $\begin{array}{c}\text { Desvio } \\
\text { Padrão }\end{array}$ & Mínimo & Máximo \\
\hline \hline \multirow{3}{*}{ Idade } & Estudo & 70 & 21,99 & 21,00 & 4,83 & 15 & 37 \\
& Controle & 62 & 20,81 & 20,50 & 4,08 & 15 & 35 \\
& Total & 132 & 21,43 & 21,00 & 4,52 & 15 & 37 \\
\cline { 2 - 8 } IG & Estudo & 70 & 39,24 & 39,00 & 1,10 & 37 & 42 \\
\multirow{2}{*}{ (semanas) } & Controle & 62 & 38,87 & 39,00 & 1,02 & 37 & 41 \\
& Total & 132 & 39,07 & 39,00 & 1,07 & 37 & 42 \\
\hline \hline
\end{tabular}

\subsection{Acompanhamento das parturientes}

As parturientes foram acompanhadas pela mesma fisioterapeuta durante todo o trabalho de parto até a dilatação total.

Iniciou-se o acompanhamento após avaliação obstétrica, ou seja, diagnóstico de trabalho de parto, ausculta do feto, avaliação da bacia e 
posição fetal, avaliação da dinâmica uterina e da dilatação cervical. Esses dados foram registrados em protocolo pré-estabelecido, descrito no anexo D.

A primeira abordagem terapêutica, foi por meio da coleta dos dados pessoais da parturiente. Apesar dos mesmos constarem no prontuário, foram confirmados intencionalmente, junto à mesma. As informações e a história da parturiente foram colhidas de maneira informal, incentivando-a falar livremente, com o objetivo de estabelecer o início do vínculo terapêutico, já que a relação com a paciente se iniciou durante o trabalho de parto.

Durante o acompanhamento, foram registrados: os sinais vitais da parturiente, o controle da dinâmica uterina e da dilatação cervical, a monitoração fetal e as intervenções farmacológicas, além dos procedimentos fisioterapêuticos empregados em cada fase do trabalho de parto e a avaliação psicomotora da parturiente (anexo D).

A abordagem fisioterapêutica respeitou os protocolos assistenciais do Hospital Universitário e não interferiu nas condutas clínicas, manteve-se a permanência do acompanhante da parturiente (companheiro ou familiar), que costuma fazer parte da rotina do atendimento, além da presença dos residentes e internos do curso de medicina.

A evolução da dilatação cervical e da descida do pólo cefálico foram registradas no partograma de Philpott e Castle ${ }^{68}$.

Após o parto foram registrados: a duração total da fase ativa, o uso de analgesia ou anestesia para o parto, o tipo de parto, peso e índices de Apgar do recém-nascido (anexo D). 
Os procedimentos utilizados seguiram um método terapêutico que enfatizou: $1^{\circ}$ ) o uso da mobilidade corporal durante o trabalho de parto; $2^{\circ}$ ) o uso da linguagem.

\subsubsection{Mobilidade corporal}

A mobilidade corporal foi usada dentro dos princípios da coordenação motora, isto é, o movimento organizado depende do comando consciente da musculatura estriada.

O uso da mobilidade corporal em coordenação, seguiu a abordagem terapêutica do Método das Cadeias Musculares GDS ${ }^{69}$ : a organização da musculatura em cadeias de músculos, ou seja, compreender que os movimentos não foram realizados de forma segmentar.

A orientação e ação sobre o corpo durante o trabalho de parto respeitaram o conceito que a organização postural é suporte de uma forma de ser, de se comportar, se exprimir, criar um universo particular e realizar as próprias motivações ${ }^{69}$. A atitude psicomotora de cada parturiente, as limitações de movimento e as marcas de alterações posturais foram vistas e respeitadas como expressão de uma individualidade.

A mobilidade corporal foi dirigida para movimentos específicos visando o trabalho de parto: posturas verticais, movimento articular geral, mobilidade pélvica, relaxamento do períneo, coordenação do diafragma e estímulo da propriocepção. 
Métodos

A ação da fisioterapeuta adaptou-se às habilidades motoras individuais e a resposta corporal de cada parturiente, porém os procedimentos foram os mesmos para todas as participantes do estudo.

As orientações fisioterápicas foram guiadas pelas exigências de cada período funcional do trabalho de parto: dilatação cervical e descida fetal no canal de parto.

O grau da descida do pólo cefálico foi avaliado pelo método de De Lee e informado à fisioterapeuta após o exame de toque vaginal realizado pelo obstetra.

As posturas e a mobilidade da parturiente foram distintas, durante a contração e nos intervalos da contração.

A seguir, detalhamos como o acompanhamento se diferenciou em cada fase do trabalho de parto, levando-se em conta a insinuação, descida e desprendimento fetal.

\subsubsection{Mobilidade corporal na insinuação fetal.}

Para acompanhar, facilitar ou estimular a insinuação do pólo cefálico fetal, a postura e a mobilidade da parturiente foram orientadas no sentido de ampliar os diâmetros do estreito superior, por meio de pequenos movimentos das articulações lombo-sacro, sacro-íliacas, coxo-femurais e sínfise púbica ${ }^{70}$. A movimentação foi orientada mesmo que o grau da apresentação ainda estivesse em -3 do plano de De Lee , desde que, com dilatação cervical entre 3 e 4cm e presença de atividade uterina. 
Os procedimentos foram distintos durante e nos intervalos das contrações, como mostramos a seguir.

\section{$\left.1^{\circ}\right)$ Procedimentos durante as contrações:}

Durante a fase da insinuação fetal, as parturientes foram estimuladas a ficarem em pé ou sentadas em cadeira ou na cama. Foram estimuladas no sentido de alcançar a melhor amplitude dos diâmetros do estreito superior da bacia ${ }^{71,72}$. As orientações foram as seguintes:

- correção da lordose lombar com verticalização do sacro;

- adutores de coxa em distensão ou relaxados com inibição da rotação interna das articulações coxofemurais;

- respiração livre sem inspiração ou expiração profundas;

- estímulo para a percepção do gradiente descendente da contração uterina;

- pelve em contra-nutação, para ampliar o diâmetro antero-posterior do estreito superior; o movimento foi orientado de maneira a fazer o platô sacral recuar para trás (em relação aos ilíacos) e o cóccix avançar para frente (Figura 1), ao mesmo tempo a parturiente foi sensibilizada a perceber a posição fetal (Figura 2);

- tronco mantido em leve inclinação para frente, seguindo a orientação oblíqua do estreito superior em relação ao eixo vertebral (Figura 3).

- inibição da rotação interna da cintura escapular

- região cervical em leve flexão, para facilitar a postura em coordenação. 


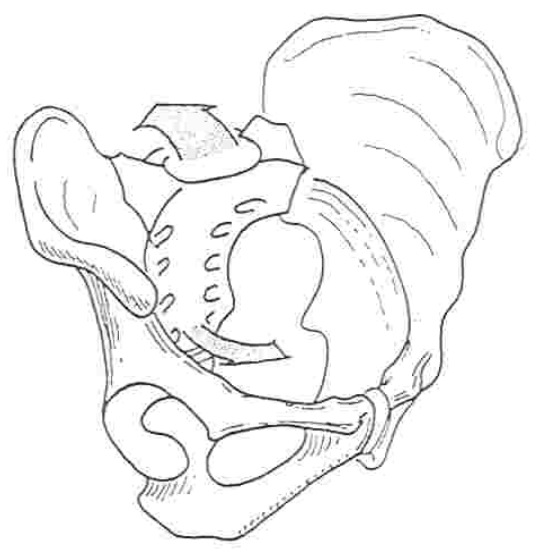

Fonte:Calais-Germain
Figura1: contra-nutação da pelve; as setas mostram o sentido do movimento

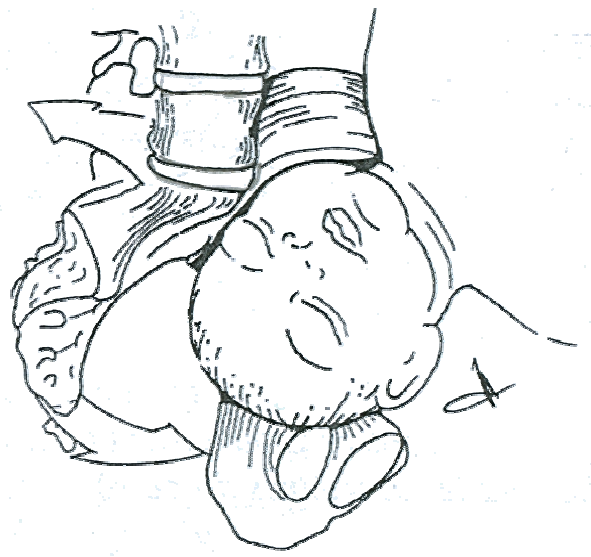

Figura 2: contra-nutação e insinuação Fonte:Calais-Germain

Levando-se em conta as orientações biomecânicas, as figuras 4, 5, 6, a seguir, demonstram as posições verticais que foram usadas durante as contrações. Em cada contração, a parturiente experimentava uma nova postura, alternando-as. A fisioterapeuta avaliava a posição mais fácil e mais

eficiente para abertura do estreito superior da bacia e para facilitar a insinuação fetal e também, a mais prazerosa para cada parturiente para ser repetida numa próxima contração ${ }^{71,72}$. 

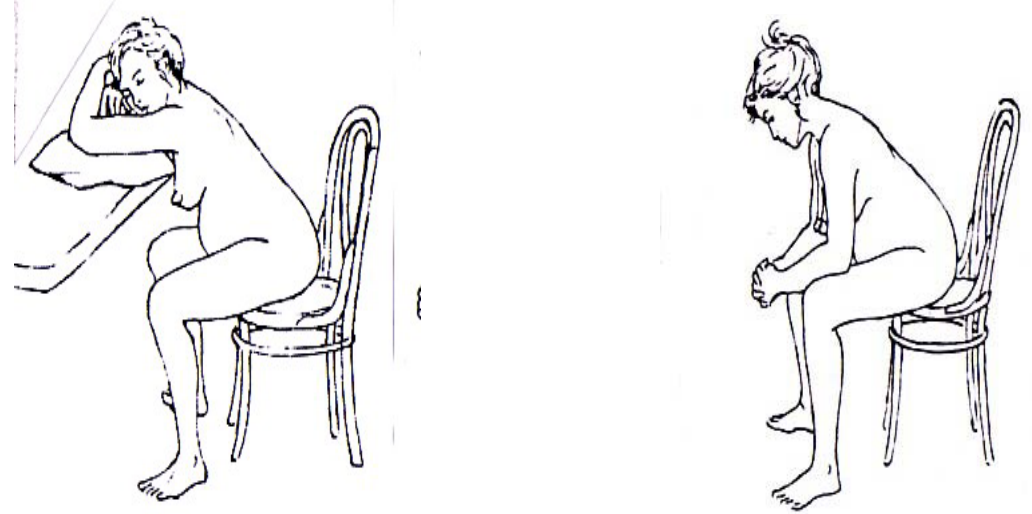

Fonte:Balaskas

Figura 3: Posições sentadas em contra-nutação, correção da lordose lombar, verticalização do sacro, inclinação do tronco.
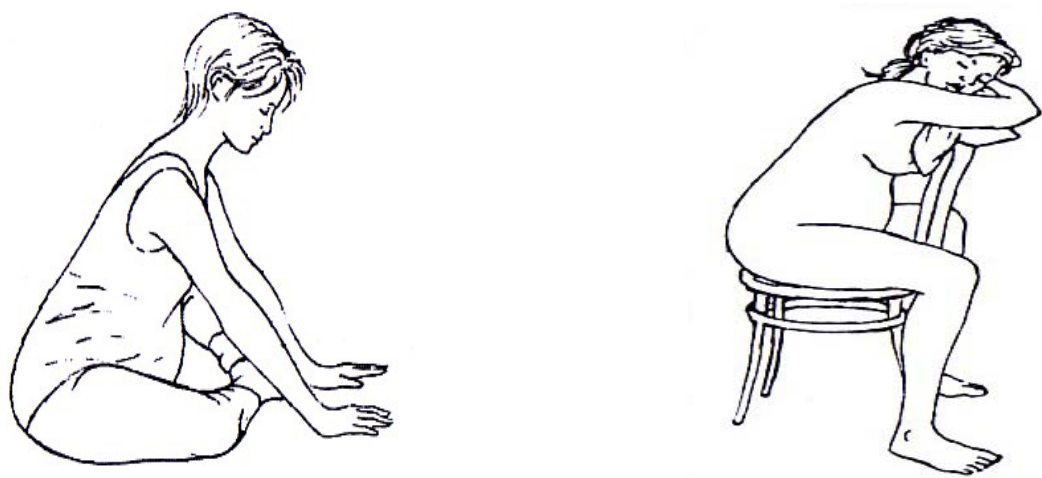

Fonte:Balaskas

Figura 4: Posições sentadas com distensão dos adutores, inibição da rotação interna do quadril e inclinação do tronco.
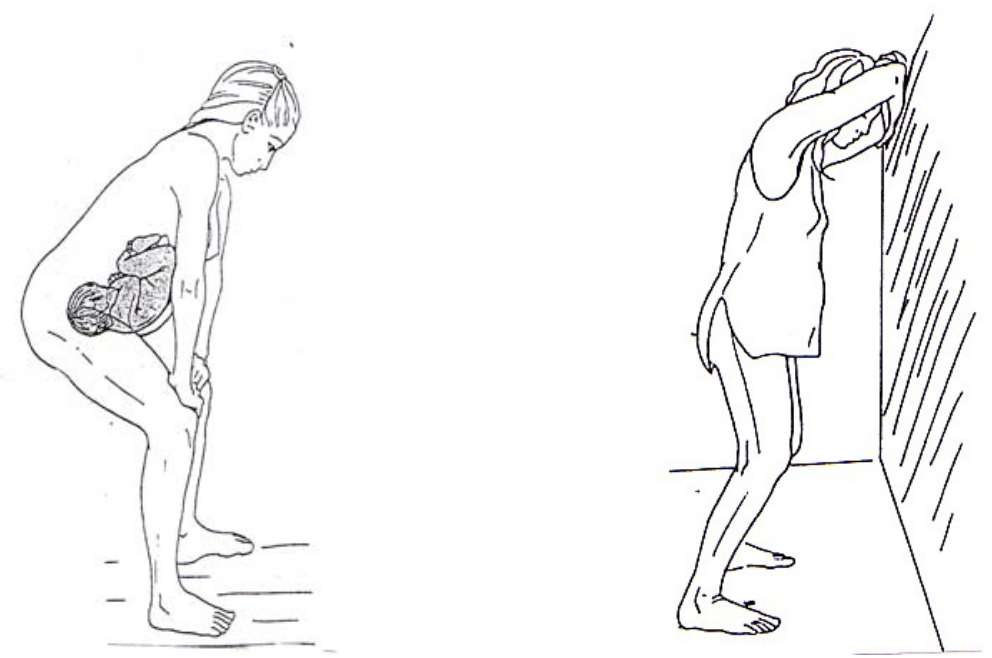

Fonte:Balaskas

Figura 5: Posições em pé em contra-nutação, com correção da lordose lombar, verticalização do sacro, inclinação do tronco e leve flexão cervical. 
$2^{\circ}$ ) Procedimentos nos intervalos das contrações durante a insinuação fetal:

As parturientes foram orientadas na mobilidade da seguinte forma:

- em posição em pé mobilização articular geral, movendo- se livremente;

- andar a favor do peso gravitacional, com leve flexão de joelho, pelve em balanço lateral distribuindo o peso do corpo e abdome entre o períneo e articulações coxofemurais $^{73}$ (Figuras 6 e 7);

- respiração livre, mas com incentivo para a expiração.

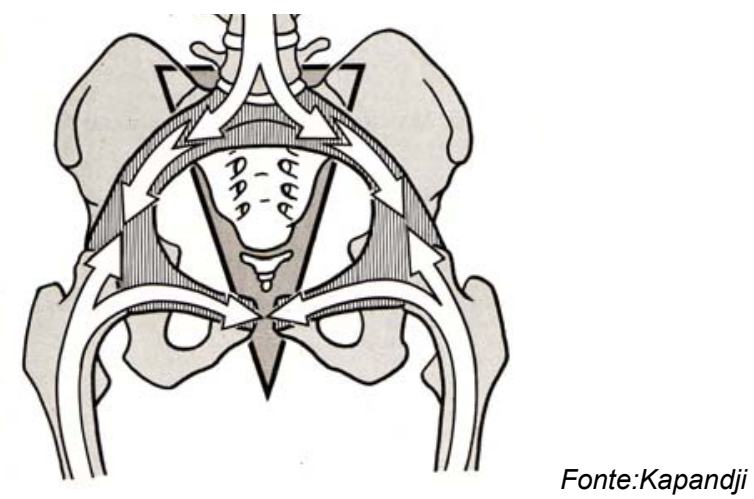

Figura 6: Distribuição do peso na cintura pélvica.
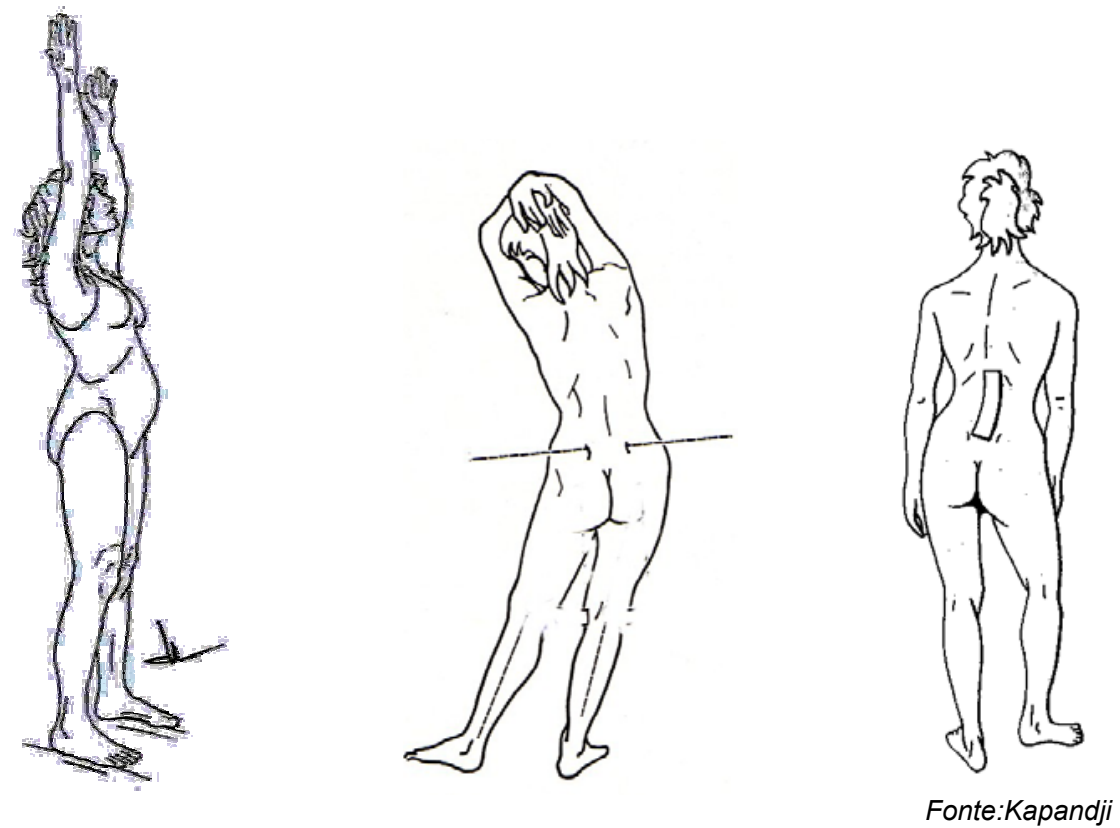

Figura 7: Mobilização articular geral e mobilização pélvica. 
- em posição sentada, mobilização das articulações da bacia entre si, inibindo a contração do períneo (Figuras 8, 9 e 10).
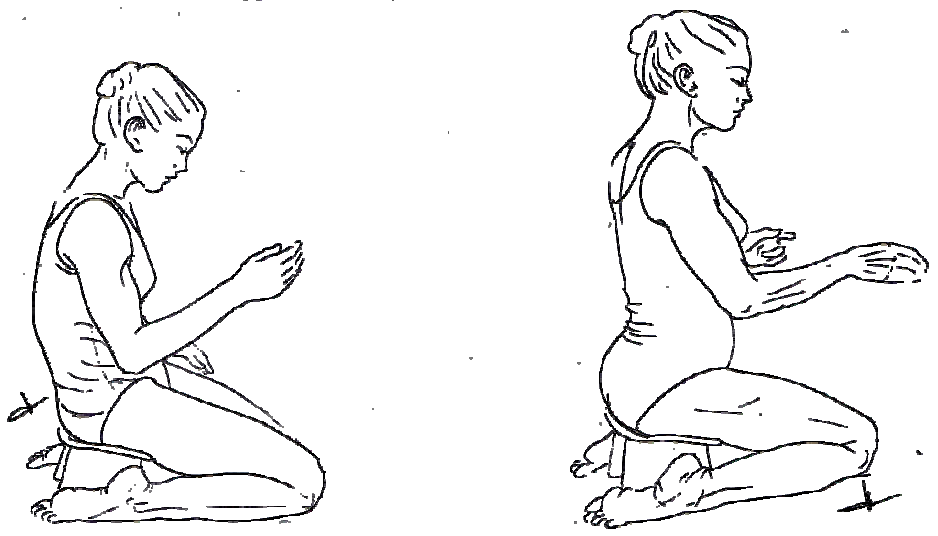

Figura 8: Mobilização da articulação lombo-sacra e das vértebras lombares entre si.
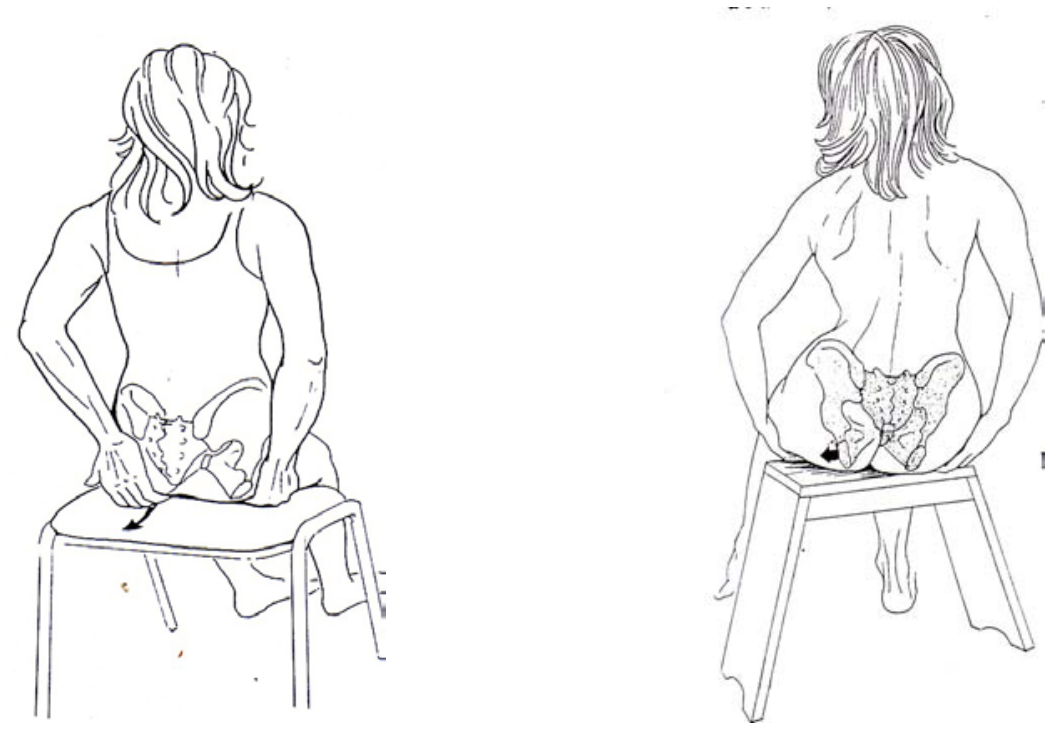

Fonte:Calais-Germain

Figura 9: Mobilização das articulações sacro-ilíacas e coxofemurais. 


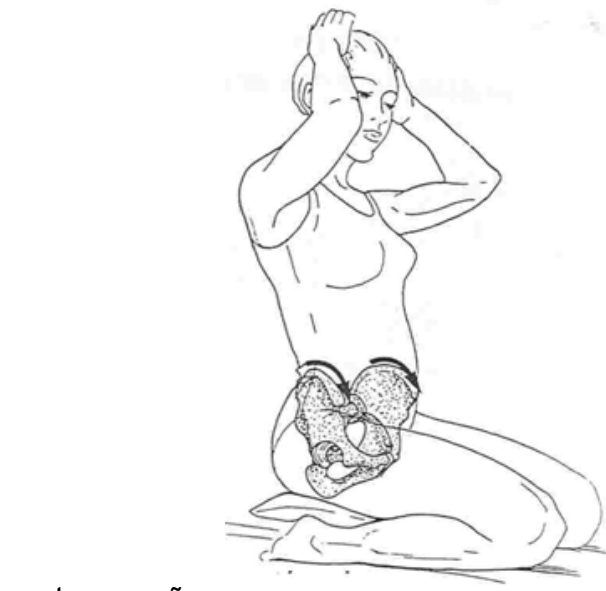

anteroversão

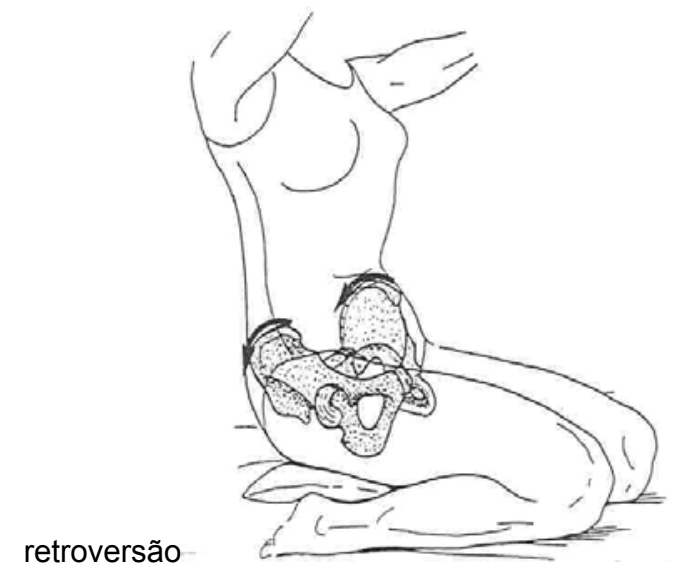

Fonte:Calais-Germain

Figura 10: Mobilização da pelve sobre a articulação coxofemural.

As parturientes mantiveram-se em movimento durante o período sem contração, experimentando uma ou mais das posições citadas. A fisioterapeuta, orientou a respiração, coordenou o movimento e corrigiu os vícios pélvicos que foram observados durante o movimento.

\subsubsection{Mobilidade corporal na descida fetal}

Para facilitar a descida e rotação fetal pelo estreito médio até atingir o estreito inferior da bacia, as parturientes foram orientadas em movimentos e posturas visando aumentar o espaço sacro-púbis, ampliar o diâmetro biciático, afastar os ísquios e ampliar o diâmetro biisquiático, liberar a flexão do cóccix e gerar elasticidade no períneo. 
A partir do plano zero de De Lee e da progressão fetal pela escavação pélvica, a prioridade foi inibir a ação dos músculos profundos do períneo sobre os diâmetros do estreito médio e músculos superficiais sobre o estreito inferior da bacia.

A seguir, detalhamos como as posturas e a movimentação foram orientadas à parturiente durante e nos intervalos das contrações.

\section{$\left.1^{\circ}\right)$ Procedimentos durante as contrações:}

$\mathrm{Na}$ fase da descida fetal pela bacia, as parturientes foram estimuladas a ficarem em posturas verticais, em pé, sentadas em cadeira ou na cama, ajoelhadas ou de cócoras, com a atenção voltada para a direção da contração uterina dentro do espaço pélvico e para a percepção da descida fetal e conseqüente aumento da pressão perineal. As orientações corporais foram as seguintes:

- pelve em nutação, para aumentar o diâmetro antero - posterior (sacropúbis): o platô sacral se desloca para frente (em relação aos ilíacos), o cóccix se desloca para trás e as tuberosidades isquiáticas se afastam.

$\mathrm{Na}$ figura 11, as setas mostram como foi dirigida a orientação para o movimento de nutação da pelve, conscientizando a parturiente da posição fetal em flexão, contra o sacro na descida pelo estreito médio ( Figura 12). 


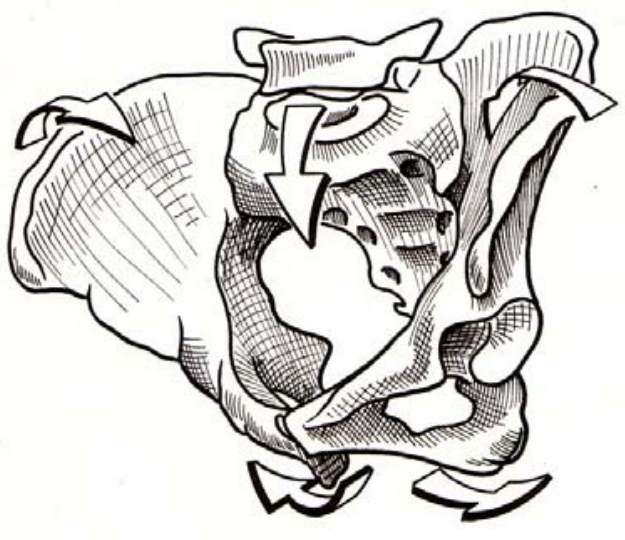

Fonte:Kapandji

Figura 11: Nutação da pelve

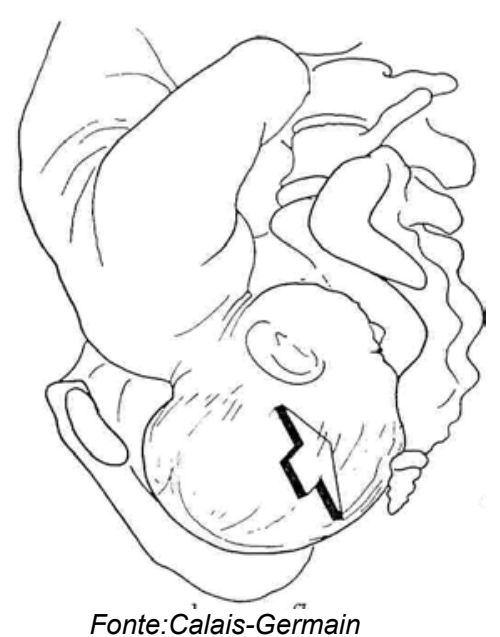

Figura 12: Posição fetal no estreito médio

- expirar no início da contração;

- evitar o bloqueio diafragmático em inspiração, para não imobilizar o diafragma pélvico;

- evitar a respiração profunda;

- relaxar a musculatura respiratória acessória (trapézio superior, escalenos);

- coxas em abdução e coxo-femurais em rotação externa;

- a partir da posição vertical favorecendo a abertura do estreito médio e inferior e da coordenação do movimento diafragmático, a atenção e percepção da parturiente foi dirigida para a inibição da contração reativa do períneo, frente a pressão progressiva do pólo cefálico

Na passagem fetal pelo estreito médio, plano de De Lee +1 e +2 , foram orientadas para o relaxamento do diafragma pélvico, no sentido de diminuir o comando voluntário da força ativa da musculatura profunda do períneo e 
ampliar o diâmetro biciático. A figura 13 mostra a relação da estrutura articular da pelve com o plano muscular, orientando as posturas empregadas que estão descritas nas figuras 14, 15 e 16 adiante.
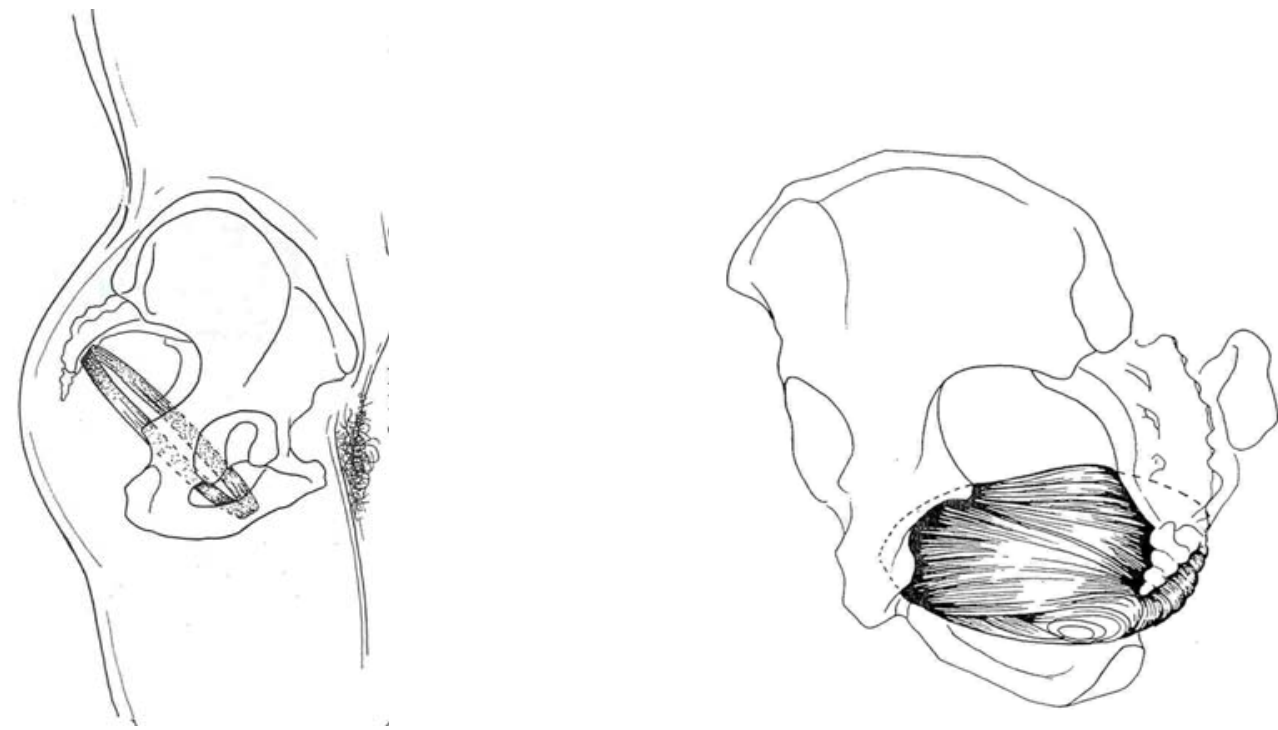

Fonte: Calais-Germain

Figura 13:Relação do estreito médio da bacia e diafragma pélvico.

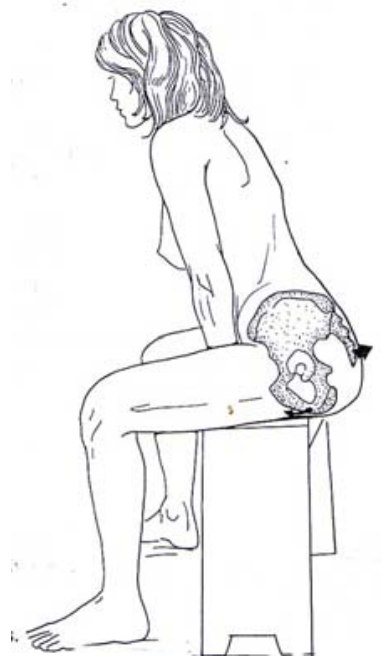

Fonte: Calais-Germain

Figura 14: Posição sentada em nutação, na direção da descida fetal e abertura do espaço sacro-púbis. 


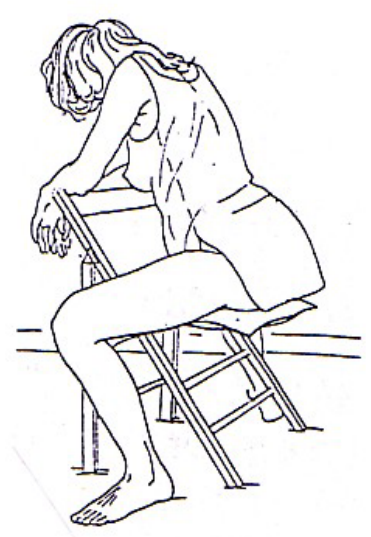

Fonte: Calais-Germain

Figura 15: Posição sentada em nutação, abdução e rotação externa e abertura do diâmetro biciático.

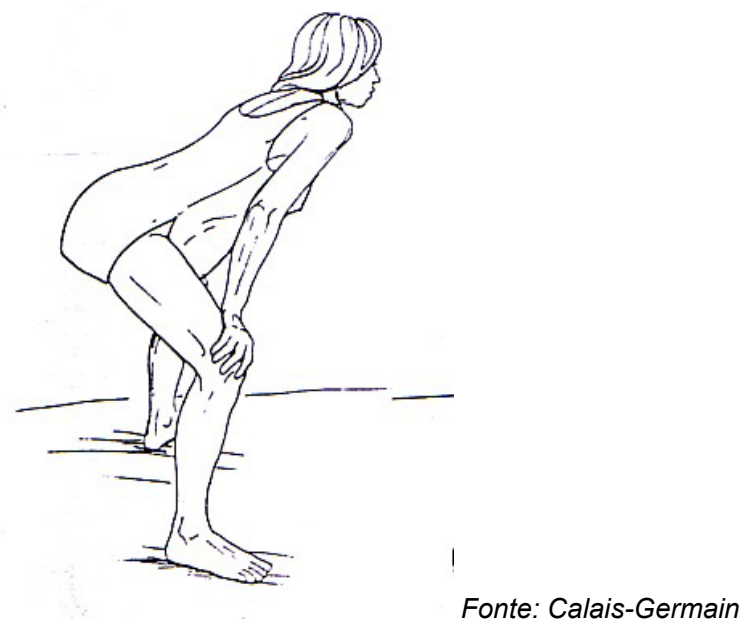

Figura 16: Posição em pé em nutação, abdução e rotação externa e inibição da contração do períneo.

$\mathrm{Na}$ progressão fetal para o estreito inferior, a partir do plano de De Lee +3 , as parturientes foram orientadas em posturas para inibir a contração do períneo e sensibilizadas a abandonar o controle muscular voluntário. As figuras17 e 18 mostram a influência da musculatura superficial do períneo sobre os diâmetros do estreito inferior da bacia que determinaram as posturas usadas nessa fase (Figuras 19,20,21) 


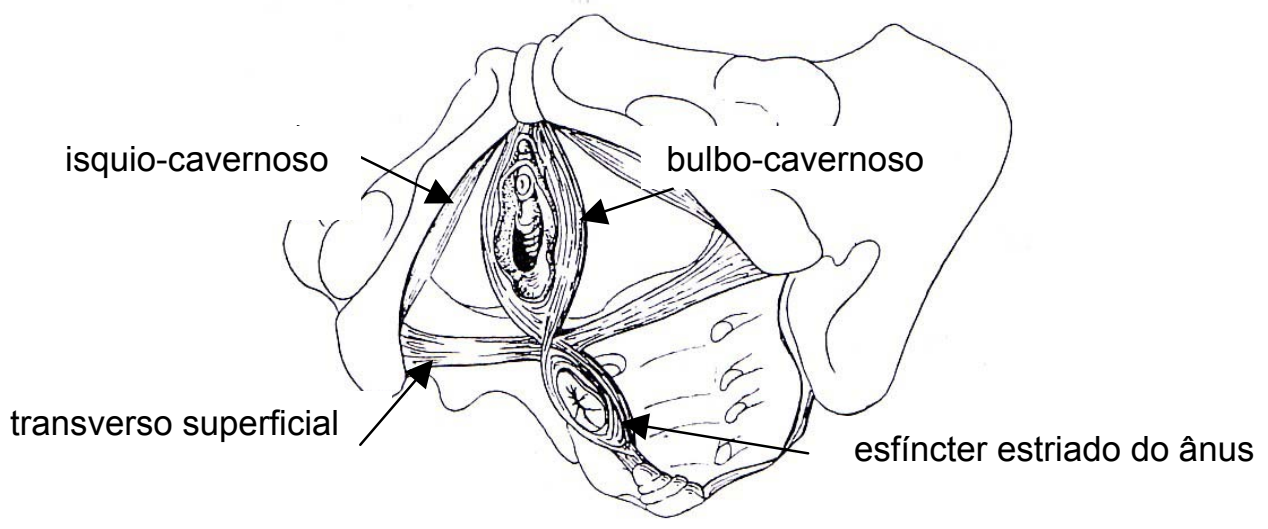

Fonte: Calais-Germain

Figura 17: Musculatura superficial do períneo.
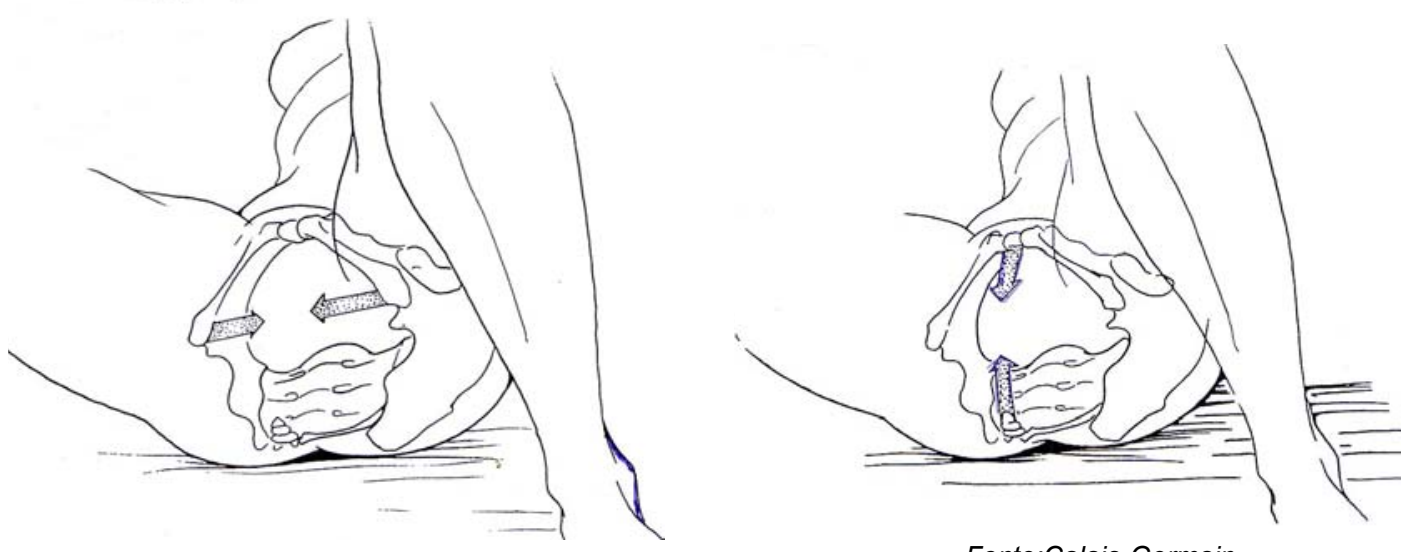

Fonte:Calais-Germain

Figura 18: Ação dos músculos do períneo nos diâmetros do estreito inferior.
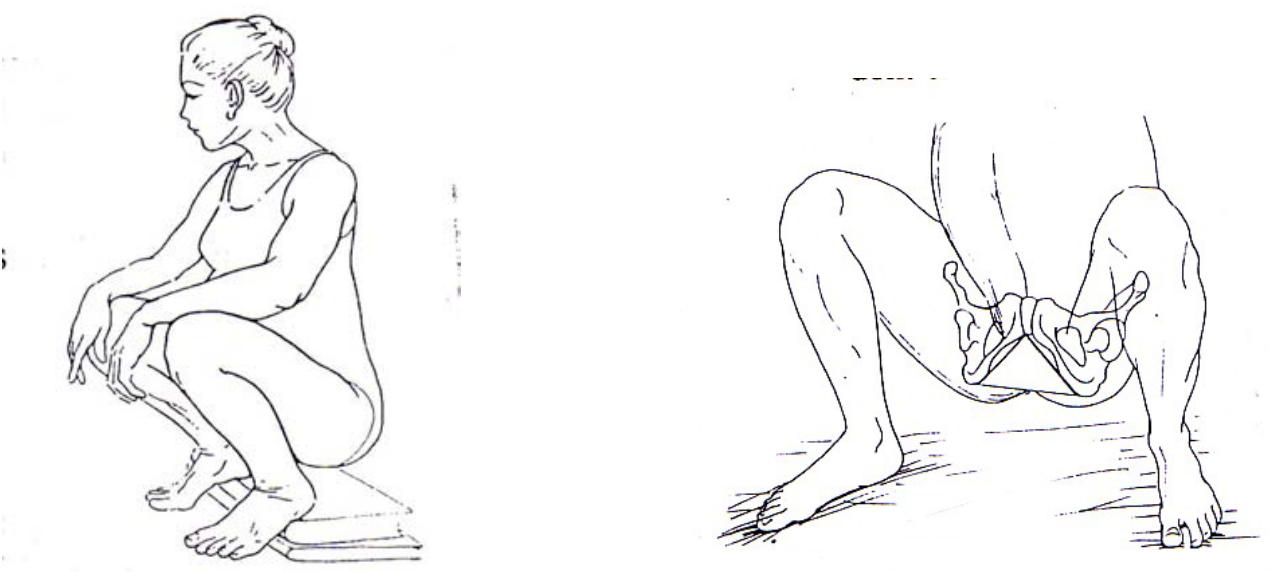

Fonte:Calais-Germain

Figura 19: Posição de abertura do estreito inferior e relaxamento do períneo anterior. 

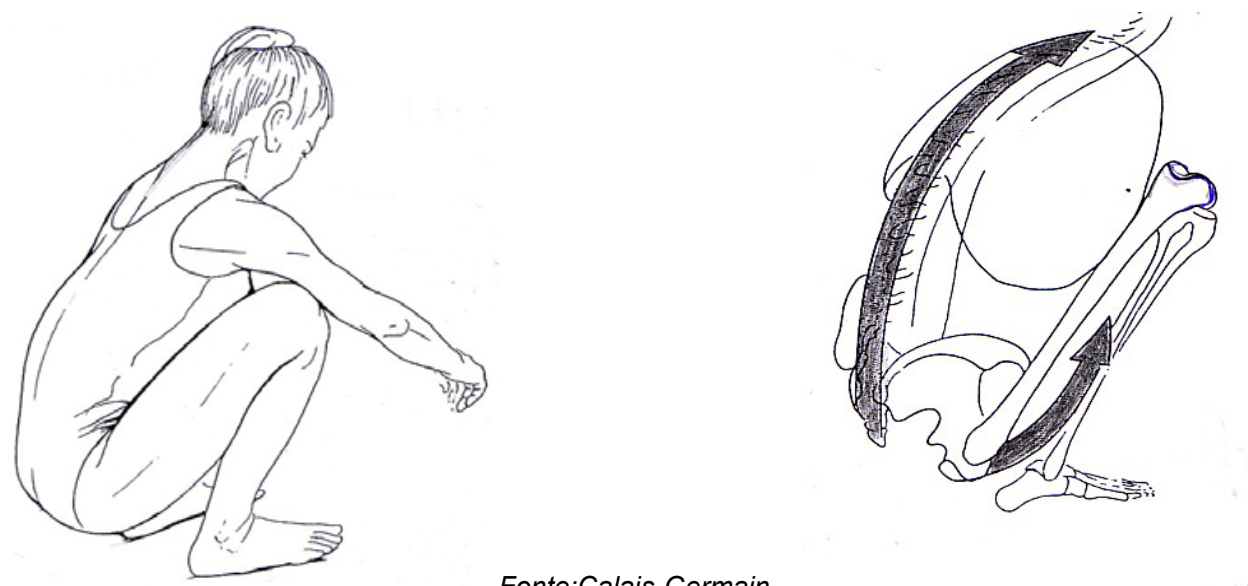

Fonte:Calais-Germain

Figura 20: Posição de cócoras e inibição da contração do períneo.

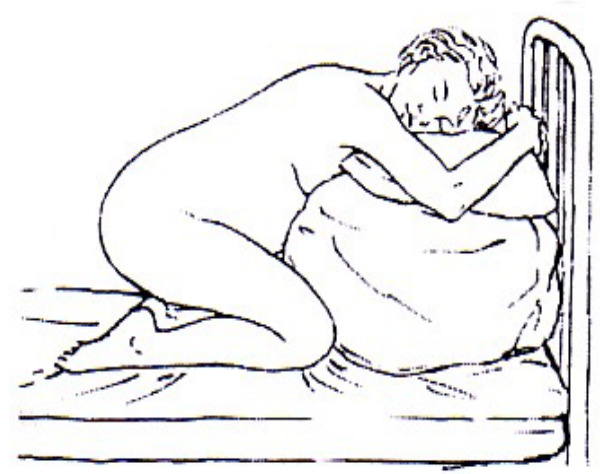

Fonte:Balaskas

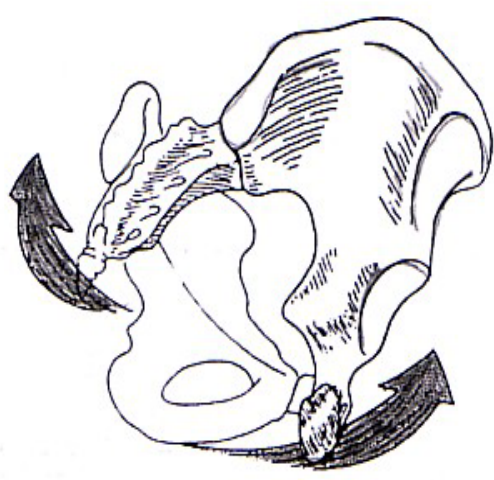

Fonte:Calais-Germain

Figura 21: Posição ajoelhada e abertura do estreito inferior da bacia.

\section{$\left.2^{\circ}\right)$ procedimentos nos intervalos das contrações:}

Durante a evolução da descida fetal, nos intervalos entre as contrações, as parturientes foram auxiliadas a manter a mobilidade corporal, alternando posições verticais em pé, sentadas ou andando, mantendo o relaxamento do períneo e coordenando a respiração ${ }^{74}$. 
As figuras 22, 23 e 24, mostram as posições usadas nesse período.

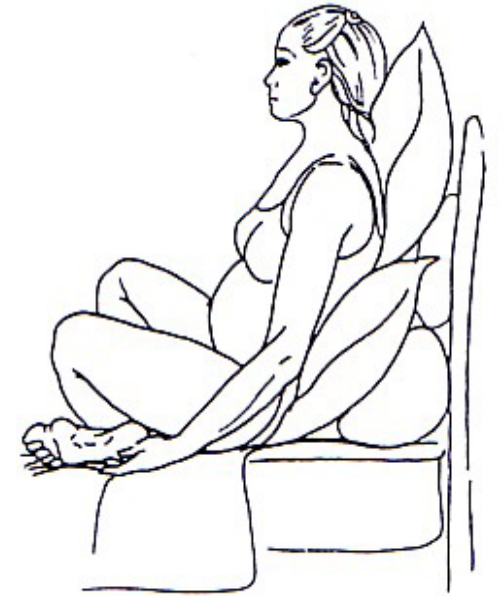

Fonte: Balaskas

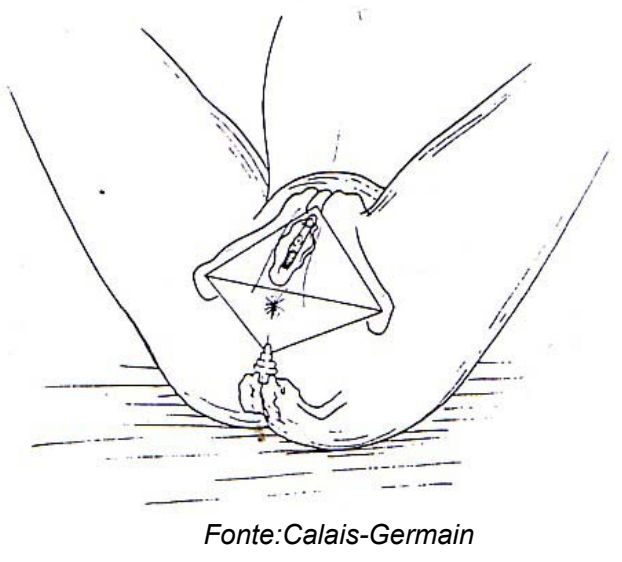

Figura 22: Posição em distensão de adutores, relaxamento do períneo e ampliação do diâmetro biisquiático.

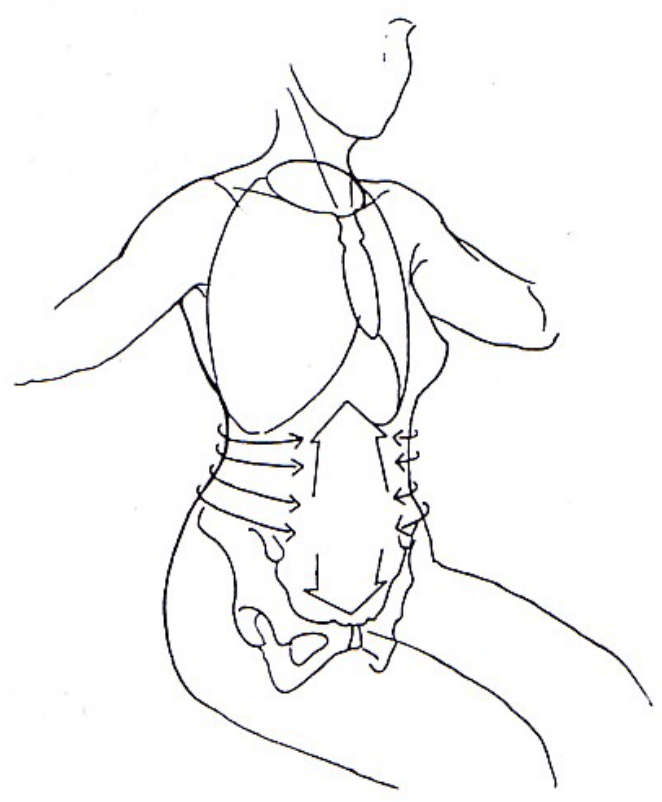

Fonte:Campignion

Figura 23: Coordenação da respiração dinâmica. As setas indicam as direções da inspiração e expiração dinâmica. 


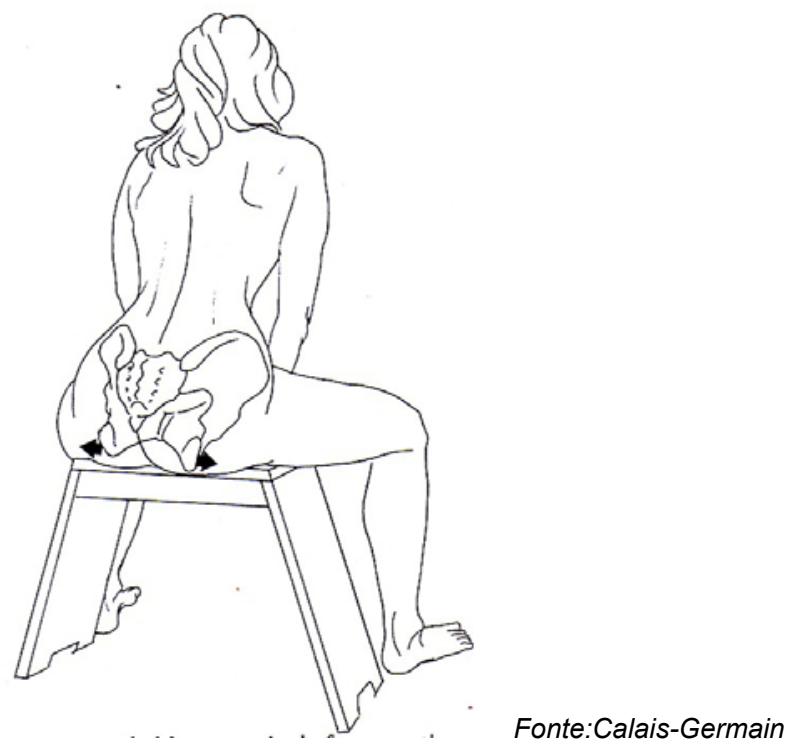

Figura 24: Mobilização pélvica com abertura dos ísquios.

$\mathrm{Na}$ evolução da descida fetal, sendo os intervalos sem contração mais curtos,a parturiente foi auxiliada principalmente no relaxamento geral, isto é, a abandonar as ordens de contração (conscientes e inconscientes) da musculatura estriada.

A figuras 25, a seguir, mostra como foi realizada a seqüência de movimentos da parturiente, considerando o ritmo da evolução da dilatação, os períodos sem contração intercalados com as contrações, numa visão de conjunto de como ocorreu a dinâmica corporal ao longo do processo de trabalho de parto.

A intervenção fisioterapêutica terminou com o final da dilatação cervical. A fisioterapeuta acompanhou a parturiente à sala de parto, para não romper bruscamente o vínculo estabelecido e integrou-se à equipe obstétrica, estimulando a participação ativa da parturiente no parto, orientando a força diafragmática e abdominal para a expulsão fetal. 

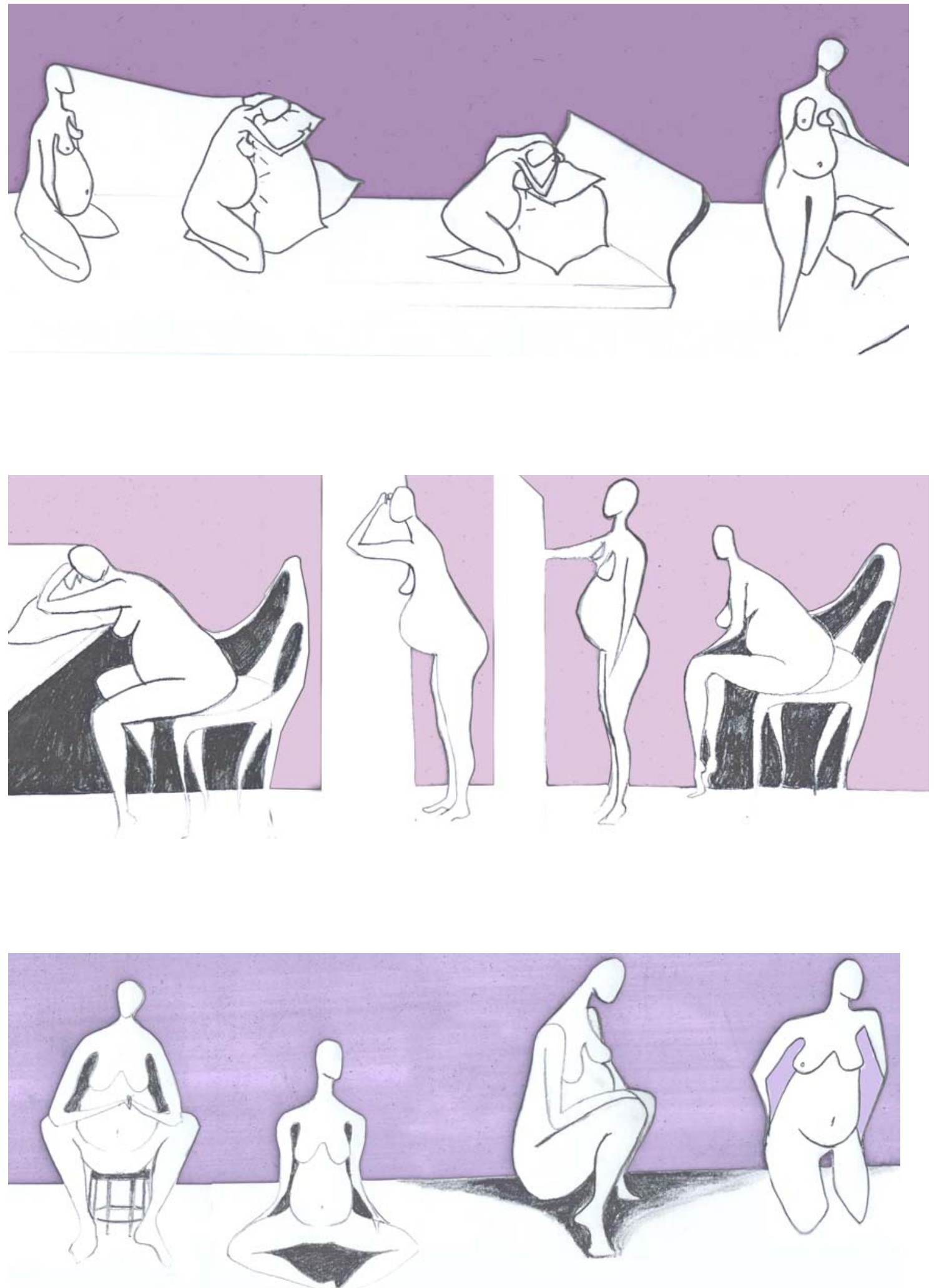

Marcela Giotto Levy

Figura 25: Seqüência de movimentos da parturiente ao longo do trabalho de parto. 


\subsubsection{O uso da linguagem}

A linguagem foi intencionalmente usada como recurso terapêutico.

A linguagem foi dirigida para ser uma ponte de comunicação terapêutica, dentro do universo lingüístico da parturiente e assim, comandar o uso coordenado da musculatura estriada, nomear adequadamente sensações e queixas e dirigir o foco da atenção para a percepção corporal.

O objetivo de cada postura ou movimento foi explicado à parturiente em linguagem simples, evitando o vocabulário especializado, porém de maneira a facilitar a construção neuromuscular do movimento, controlando o excesso de tônus muscular.

As informações da parturiente e sua história, deixando-a falar livremente, nos revelavam seu nível cultural e os significados dados ás sensações corporais. O conteúdo da fala foi valorizado no sentido de revelar a representação social do parto e nascimento, para cada uma. O conhecimento sobre o parto, os respectivos elementos cognitivos, as representações mentais, foram registros usados para integrar o significado simbólico do processo do parto à ação voluntária e consciente do corpo.

A linguagem não pretendeu aumentar a atividade cortical da parturiente, ao contrário, estimulou a identificação das informações sensoriais. 


\subsection{Categorias de análise}

Os parâmetros selecionados para análise e discussão foram:

$\left.1^{\circ}\right)$ tipo de parto: vaginal, fórcipe, cesárea;

$2^{\circ}$ ) tempo de duração da fase ativa do trabalho de parto, dos 3 aos $10 \mathrm{~cm}$ de dilatação;

$3^{\circ}$ ) relação entre a duração da fase ativa e a condição da bolsa das águas (íntegra ou rota);

$4^{\circ}$ ) relação entre a duração da fase ativa e o esvaecimento do colo uterino (fino, médio e grosso);

$\left.5^{\circ}\right)$ uso de analgésicos durante a fase ativa;

$\left.6^{\circ}\right)$ uso de anestesia para analgesia do parto;

$7^{\circ}$ ) uso de anestesia e nível da dilatação cervical;

$8^{\circ}$ ) peso dos recém-nascidos em gramas;

$9^{\circ}$ ) índices de Apgar dos recém-nascidos;

Essas categorias foram consideradas varáveis de desfecho, na análise dos resultados do grupo de tratamento e na comparação com o grupo controle.

\subsection{Análise estatística}

Para análise descritiva da caracterização das parturientes estudadas, nas variáveis quantitativas (idade e idade gestacional), foram utilizadas médias e medianas para resumir as informações e desvios-padrão, mínimo e máximo para indicar a variabilidade dos dados; nas variáveis qualitativas 
(cor, escolaridade e tipo de parto) foram apresentadas as freqüências relativas (percentuais) e absolutas $(\mathrm{N})$.

$\mathrm{Na}$ análise da homogeneidade dos grupos (estudo e controle), foram aplicados: o teste Qui-Quadrado de Pearson ou o teste exato de Fisher, para avaliar se as proporções em cada grupo foram semelhantes, nas variáveis qualitativas; o teste não paramétrico de Mann-Whitney e o teste paramétrico t-Student, nas variáveis quantitativas ${ }^{75,76}$.

Para análise das variáveis de desfecho, foram aplicados: o teste não paramétrico de Mann-Whitney, nas variáveis quantitativas (duração da fase ativa, duração da fase ativa em relação à condição da bolsa amniótica e à condição do colo e índices de Apgar dos recém-nascidos); o teste QuiQuadrado de Pearson ou o teste exato de Fisher quando necessário, na análise das variáveis qualitativas (condição da bolsa amniótica, uso de analgésico, uso de anestesia e nível da dilatação cervical no uso de anestesia); o teste paramétrico t-Student, para análise e comparação do peso dos recém-nascidos. Foram considerados estatisticamente significantes os resultados cujos níveis descritivos (valores de p) foram inferiores a 0,05.

Foram usados os softwares: MSOffice Excel versão 2000, para o gerenciamento do banco de dados; SPSS for Windows versão 10.0Statistical Pachage for the Social Science, para execução dos cálculos estatísticos, elaboração e edição de gráficos; MSOffice Word versão 2000, na elaboração das tabelas. 
5. RESULTADOS 
A amostra estudada foi de 132 parturientes: 70 no grupo de estudo e 62 no grupo controle.

Das 70 parturientes do grupo de estudo 62 (89\%) evoluíram para parto vaginal e $8(11 \%)$ para cesárea (Figura 26$)$.

Todas as parturientes aceitaram o acompanhamento da fisioterapeuta para se manterem em movimento e em posturas verticais durante o trabalho de parto, isto é, não foi encontrada nenhuma resistência à participação do estudo.

A apresentação e análise dos resultados foram feitas segundo a caracterização das parturientes acompanhadas.

\subsection{Caracterização das parturientes do grupo de estudo}

As parturientes estudadas foram classificadas em três grupos (Figura 26): grupo de estudo 1: 50 parturientes acompanhadas, que evoluíram para parto vaginal sem uso de ocitócico durante a fase ativa, com respectivo grupo controle

grupo de estudo 2: 12 parturientes acompanhadas,que evoluíram para parto vaginal com uso de ocitocina durante a fase ativa,devido a hipoatividade uterina, com respectivo grupo controle grupo de estudo 3: oito parturientes acompanhadas, que evoluíram para parto cesárea; não comparadas com grupo controle 


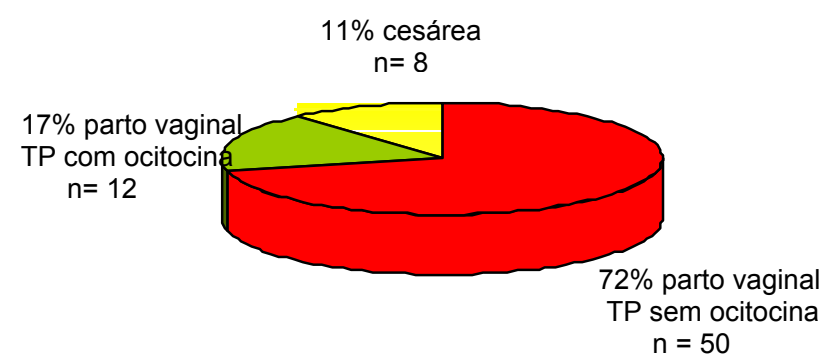

Figura 26: Distribuição das parturientes segundo o tipo de parto e uso de ocitocina durante o trabalho de parto.

\subsection{Grupo de estudo 1}

Esse grupo refere-se às parturientes acompanhadas, que não fizeram uso de ocitocina durante a evolução do trabalho de parto.

Os resultados a seguir referem-se a 100 parturientes: 50 do grupo estudo e 50 do controle que não fizeram uso de ocitocina.

Foi analisado a homogeneidade entre o grupo de estudo e o grupo controle e, em seguida, foram analisadas as variáveis de desfecho.

\subsubsection{Análise de homogeneidade dos grupos}

A análise estatística da homogeneidade dos grupos de estudo e controle, demonstrou que os mesmos foram homogêneos e, portanto comparáveis.

As categorias consideradas foram: idade materna, idade gestacional, etnia, escolaridade e peso dos recém-nascidos. 
A tabela 2 mostra a comparação entre os grupos, em relação às variáveis quantitativas: idade materna e idade gestacional.

No grupo de estudo, a média de idade foi de 22 anos (+/- 5,20), mínima de 15 anos e máxima de 37 anos; no grupo controle, a média de idade foi de 21 anos (+/- 4,41), mínima de 15 e máxima de 35 anos. Não houve, diferença significante entre os grupos $(p=0,214)$ quanto à idade materna.

A mediana da idade gestacional foi de 39 semanas tanto no grupo de estudo como no grupo controle. Não houve diferença significante entre os grupos $(p=0,109)$, indicando a homogeneidade dos grupos quanto à idade gestacional.

Tabela 2: Descrição da homogeneidade dos grupos em relação às variáveis idade materna e idade gestacional (IG).

\begin{tabular}{|c|c|c|c|c|c|c|c|c|}
\hline & Grupo & $\mathrm{N}$ & Média & Mediana & $\begin{array}{l}\text { Desvio } \\
\text { Padrão }\end{array}$ & Mínimo & Máximo & p-valor \\
\hline \multirow{3}{*}{ Idade } & Estudo & 50 & 22,44 & 22,00 & 5,20 & 15 & 37 & \multirow{3}{*}{0,214} \\
\hline & Controle & 50 & 21,02 & 21,00 & 4,41 & 15 & 35 & \\
\hline & Total & 100 & 21,73 & 21,00 & 4,85 & 15 & 37 & \\
\hline \multirow{3}{*}{$\begin{array}{c}\text { IG } \\
\text { (semanas) }\end{array}$} & Estudo & 50 & 39,18 & 39,00 & 1,10 & 37 & 42 & \multirow{3}{*}{0,109} \\
\hline & Controle & 50 & 38,82 & 39,00 & 1,04 & 37 & 41 & \\
\hline & Total & 100 & 39,00 & 39,00 & 1,08 & 37 & 42 & \\
\hline
\end{tabular}

Teste de Mann-Whitney 
Em relação à etnia, no grupo de estudo 32 parturientes (64\%) eram de cor branca, $15(30 \%)$ de cor parda e $3(6 \%)$ negras. O grupo controle apresentou perfil semelhante: a maioria branca (66\%), 15 parturientes (30\%) de cor parda e 2 (4\%) negras (Figura 30).

A análise estatística demonstrou que não houve diferença significante entre os grupos $(p>0,999)$.

grupo de estudo

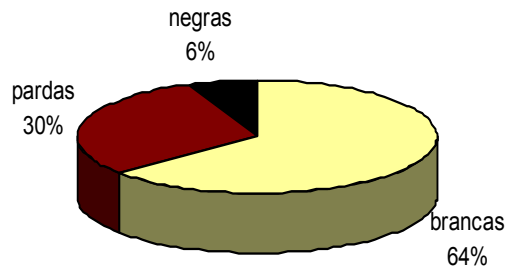

grupo controle

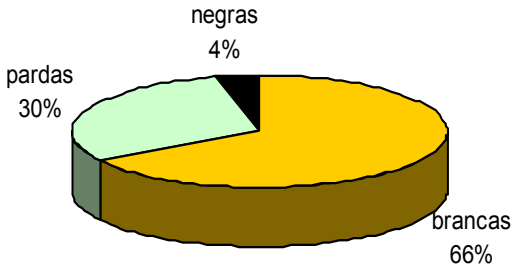

Figura 27: Distribuição percentual das etnias no grupo de estudo e controle.

Em relação ao grau de escolaridade, não houve analfabetas em nenhum dos dois grupos. No grupo de estudo $(n=50), 38 \%$ das parturientes tinham grau de instrução elementar (ensino básico completo ou incompleto); as demais $62 \%$ apresentavam grau de instrução mais elevado (ensino fundamental completo ou incompleto e nível superior). No grupo controle $(n=50), 42 \%$ das parturientes apresentavam instrução elementar e as outras $58 \%$ apresentavam grau mais elevado de instrução. 
A Figura 31 mostra a comparação entre os grupos, demonstrando a homogeneidade entre o grupo de estudo e o grupo controle em relação ao grau de instrução, já que não houve diferença significante entre eles $(p=0,185)$.

grupo de estudo

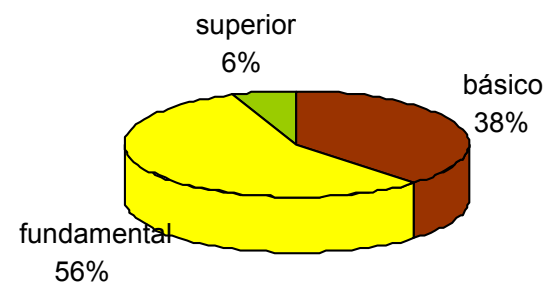

grupo controle

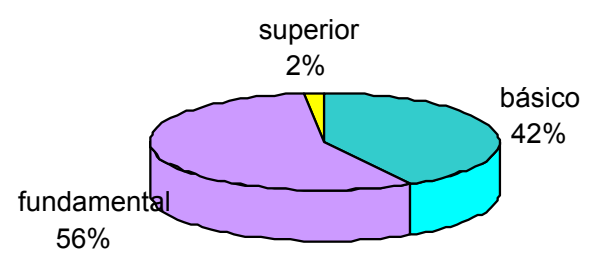

Figura 28: Distribuição das parturientes segundo o grau de instrução, nos grupos de estudo e controle.

Em relação ao peso dos recém-nascidos, no grupo de estudo a média de peso foi de $3185 \mathrm{~g}$, variando entre $2380 \mathrm{~g}$ e $3800 \mathrm{~g}$; no grupo controle a média foi de $3259 \mathrm{~g}$, variando entre $2480 \mathrm{~g}$ e $4080 \mathrm{~g}$ (Tabela 3).

A análise da comparação entre os grupos, mostrou que não houve diferença estatisticamente significante quanto ao peso dos recém-nascidos.

Tabela 3: Peso dos recém-nascidos no grupo de estudo e no grupo controle

\begin{tabular}{lllllllll}
\hline \hline & Grupo & N & Média & Mediana & $\begin{array}{c}\text { Desvio } \\
\text { Padrão }\end{array}$ & Mínimo & Máximo & p-valor \\
\hline & Estudo & 50 & 3185,90 & 3205,00 & 361,64 & 2380 & 3800 & \\
$\begin{array}{c}\text { Peso RN } \\
(\mathrm{kg})\end{array}$ & Controle & 50 & 3259,20 & 3222,50 & 365,79 & 2480 & 4080 & $\mathbf{0 , 3 1 6}$ \\
& Total & 100 & 3222,55 & 3217,50 & 363,75 & 2380 & 4080 &
\end{tabular}




\subsubsection{Análise das variáveis de desfecho}

As variáveis de desfecho consideradas foram: tipo de parto, duração da fase ativa do trabalho de parto, duração da fase ativa e condição da bolsa das águas, duração da fase ativa e esvaecimento do colo uterino, uso de analgésicos durante a fase ativa, uso de anestesia para analgesia do parto, uso de anestesia e nível da dilatação cervical e Índices de Apgar dos recém-nascidos.

\subsubsection{Tipo de parto}

O grupo de estudo $(n=50)$ e o grupo controle $(n=50)$, foram constituídos somente de parturientes com parto vaginal, porém, os resultados diferem quanto à indicação do fórcipe. No grupo de estudo, em $50 \%$ das parturientes foi usado fórcipe e no grupo controle $62 \%$ das parturientes tiveram parto fórcipe. Na comparação entre os grupos, a diferença não foi estatisticamente significante, quanto ao uso do fórcipe no parto vaginal , como demonstra a Tabela 4.

Tabela 4: Tipo de parto no grupo de estudo e no grupo controle

\begin{tabular}{|c|c|c|c|c|c|c|}
\hline & & & \multicolumn{2}{|c|}{ Grupo } & \multirow[b]{2}{*}{ Total } & \multirow[b]{2}{*}{ p-valo } \\
\hline & & & $\begin{array}{l}\text { Estudo } \\
(\mathrm{N}=50)\end{array}$ & $\begin{array}{c}\text { Controle } \\
(\mathrm{N}=50)\end{array}$ & & \\
\hline \multirow{4}{*}{$\begin{array}{l}\text { Tipo } \\
\text { de parto }\end{array}$} & \multirow{2}{*}{ Parto vaginal } & $\mathrm{N}$ & 25 & 19 & 44 & \multirow{4}{*}{0,227} \\
\hline & & $\%$ & $50,00 \%$ & $38,00 \%$ & $44,00 \%$ & \\
\hline & \multirow{2}{*}{$\begin{array}{l}\text { Parto vaginal } \\
\text { com fórcipe }\end{array}$} & $\mathrm{N}$ & 25 & 31 & 56 & \\
\hline & & $\%$ & $50,00 \%$ & $62,00 \%$ & $56,00 \%$ & \\
\hline
\end{tabular}


Resultados

Entretanto, os resultados mostraram que no grupo de estudo as parturientes que usaram fórcipe para abreviação do período expulsivo, em 19 delas a indicação foi de fórcipe de alívio e em seis parturientes o fórcipe foi devido à distocia de rotação; no grupo controle entre as parturientes que tiveram parto fórcipe, em 22 delas a indicação foi de fórcipe de alívio e em nove parturientes a indicação foi fórcipe por distocia de rotação. Observa-se portanto, que houve maior presença de distocia de rotação no grupo controle, gerando mais indicação do fórcipe ( Figura 32 ).
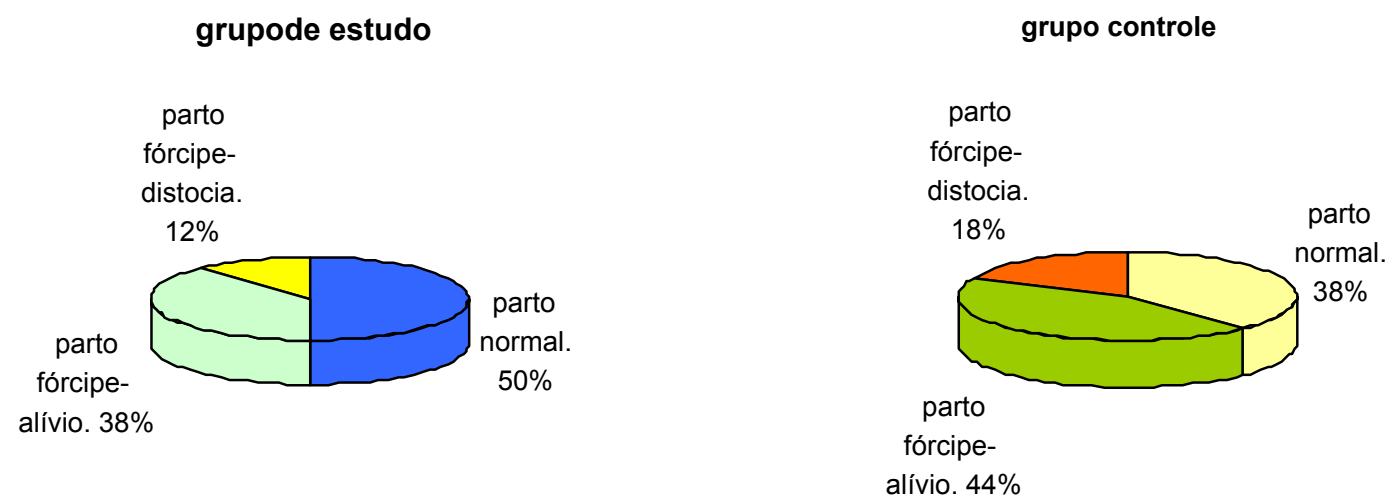

Figura 29: Distribuição das parturientes segundo o tipo de parto.

\subsubsection{Duração da fase ativa do trabalho de parto}

Na comparação dos grupos em relação ao tempo de duração da fase ativa do trabalho de parto, observou-se que no grupo de estudo a média de duração da fase ativa foi de 5 h 16 min (+/- 1,56), com variação entre 3 e 9 horas. No grupo controle a média de duração da fase ativa foi de 8 h 28 $\min (+/-2,70)$, variando entre 4 e 15 horas. 
Verificou-se diferença estatisticamente significante entre os grupos $(p<0,001)$. O grupo tratamento apresentou menor duração do período de fase ativa, com mediana de $4 \mathrm{~h}$ contra $8 \mathrm{~h}$ no grupo controle (Figura 33).

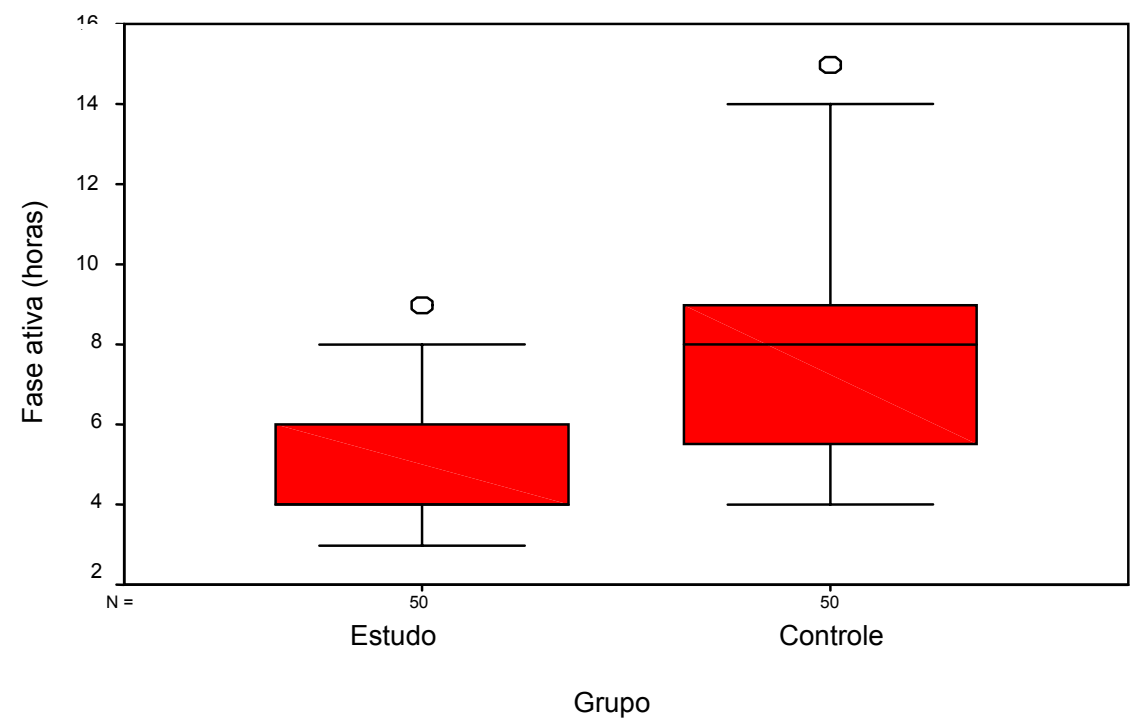

Teste de Mann-Whitney.

Figura 30: Representação gráfica da duração da fase ativa no grupo de estudo e controle.

\subsubsection{Duração da fase ativa e condição da bolsa das águas}

Foi verificado se existiu diferença no período de fase ativa, estando a bolsa das águas íntegra ou rota, no início do acompanhamento.

Os resultados referem-se a análise de cada grupo separadamente.

No grupo de estudo 33 parturientes (66\%) apresentavam a bolsa íntegra no início do acompanhamento e tiveram, em média, 5h de fase ativa, 
enquanto no grupo controle as 35 parturientes (70\%) que apresentavam a bolsa íntegra, tiveram, em média, $8 \mathrm{~h} 23 \mathrm{~min}$ de fase ativa; entre as parturientes que apresentavam a bolsa rota no início do acompanhamento, 17 parturientes (34\%) do grupo de estudo tiveram, em média, 4h29min de fase ativa e 15 parturientes (30\%) do grupo controle tiveram, em média, 7h7min de duração de fase ativa.

Observou-se que a diferença entre os grupos, na duração da fase ativa, se manteve, considerando a condição da bolsa das águas.

Na Tabela 5, vê-se a comparação na duração da fase ativa e a análise separada em cada grupo, demonstrando que os grupos continuaram comparáveis.

Tabela 5: Análise da duração da fase ativa e condição da bolsa das águas.

\begin{tabular}{lllllllll}
\hline \hline \multirow{2}{*}{ Grupo } & $\begin{array}{c}\text { Bolsa das } \\
\text { águas }\end{array}$ & $\mathrm{N}$ & Média & Mediana & $\begin{array}{c}\text { Desvio } \\
\text { Padrão }\end{array}$ & Mínimo & Máximo & p-valor \\
\hline \multirow{3}{*}{ Estudo } & íntegra & 33 & 5,00 & 5,00 & 1,72 & 3 & 9 & \\
& rota & 17 & 4,29 & 4,00 & 1,11 & 3 & 7 & 0,184 \\
& Total & 50 & 4,76 & 4,00 & 1,56 & 3 & 9 & \\
\cline { 2 - 9 } Controle & íntegra & 35 & 8,23 & 8,00 & 2,51 & 4,5 & 15 & \\
& rota & 15 & 7,07 & 5,50 & 3,05 & 4 & 14 & 0,116 \\
\hline \hline
\end{tabular}

\subsubsection{Duração da fase ativa e esvaecimento do colo}

Analisamos, também, a relação entre o esvaecimento do colo no início do acompanhamento e a duração da fase ativa, nos dois grupos. 
A distribuição das parturientes em relação ao colo foi a seguinte: apresentaram colo fino, 24 parturientes (48\%) no grupo estudo e 18 (36\%) parturientes do grupo controle; quanto a colo médio, 24 parturientes (48\%) no grupo estudo e 29 (58\%) no controle e colo grosso, o grupo estudo apresentou somente 2 parturientes (4\%) e o controle 3 parturientes (6\%). A figura 34, demonstra a comparação entre os grupos, quanto ao esvaecimento do colo uterino.

grupo de estudo

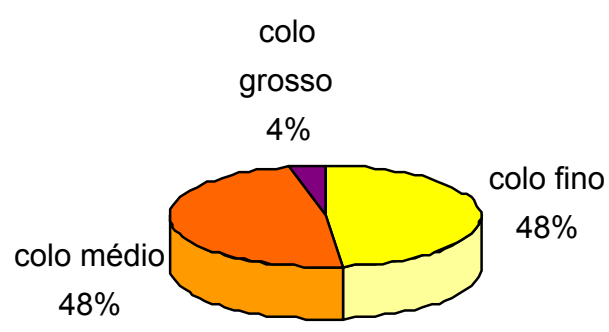

grupo controle

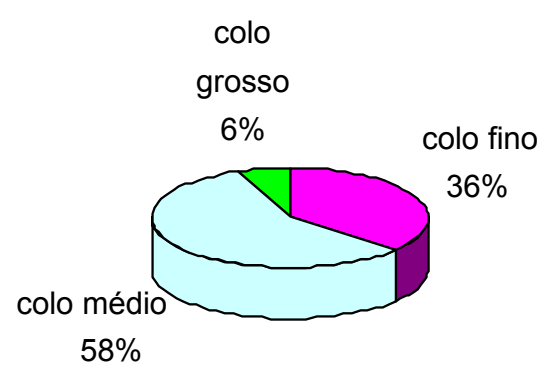

Figura 31: Classificação do colo uterino quanto ao grau de esvaecimento.

Devido ao número pequeno de parturientes que iniciaram a fase ativa com colo grosso, foi realizada uma recodificação, agrupando colo médio e grosso, numa única categoria. A seguir, foi feita a análise estatística, separada por grupo. 
Nas parturientes que iniciaram a fase ativa com colo fino, no grupo de estudo a média de duração da fase ativa foi de $4 \mathrm{~h} 11 \mathrm{~min}$ e no grupo controle $7 \mathrm{~h} 39 \mathrm{~min}$; as parturientes que tinham colo médio/grosso, no grupo de estudo tiveram 6h13min de duração de fase ativa e no grupo controle 8h16min. A análise comparativa entre os grupos, mostra que a diferença na duração da fase ativa se mantém, considerando os estágios de esvaecimento do colo. A mediana da duração da fase ativa nas parturientes com colo fino foi de $4 \mathrm{~h} 15 \mathrm{~min}$ no grupo tratamento e de $7 \mathrm{~h} 15 \mathrm{~min}$ no controle; entre as parturientes com colo médio/grosso, a mediana do tempo de fase ativa foi de $5 \mathrm{~h}$ no grupo tratamento e de 8 h15min no controle (Tabela 5).

$\mathrm{Na}$ análise separada dos grupos houve diferença estatisticamente significante $(p<0,001)$ na duração da fase ativa e esvaecimento do colo, apenas no grupo de estudo: as parturientes com colo fino apresentaram, em média, menor tempo de fase ativa (Tabela 6).

Tabela 6: Duração da fase ativa em relação ao esvaecimento do colo, separada por grupo.

\begin{tabular}{|c|c|c|c|c|c|c|c|c|}
\hline \multirow[b]{2}{*}{ Grupo } & \multirow[b]{2}{*}{ Colo } & \multicolumn{6}{|c|}{ Duração da fase ativa em horas/min.: } & \multirow[b]{2}{*}{$\mathrm{p}$-valor } \\
\hline & & $\mathrm{N}$ & Média & Mediana & Desvio Padrão & Mínimo & Máximo & \\
\hline \multirow{3}{*}{ Estudo } & Fino & 24 & 4,11 & 4,15 & 0,72 & 3 & 6 & \multirow{3}{*}{$<0,001^{*}$} \\
\hline & Médio/Grosso & 26 & 6,13 & 5,00 & 1,51 & 4 & 9 & \\
\hline & Total & 50 & 4,76 & 4,00 & 1,56 & 3 & 9 & \\
\hline \multirow{2}{*}{\multicolumn{2}{|c|}{ Controle Médio/Grosso }} & 18 & 7,39 & 7,15 & 2,60 & 4,5 & 15 & \multirow{3}{*}{0,353} \\
\hline & & 32 & 8,16 & 8,25 & 2,76 & 4 & 14 & \\
\hline & Total & 50 & 8,18 & 8,00 & 2,70 & 4 & 15 & \\
\hline
\end{tabular}




\subsubsection{Uso de analgésicos}

Quanto ao uso de analgésicos (meperidina), durante a fase ativa, observou-se que no grupo tratamento, nenhuma parturiente fez uso de fármacos, enquanto no grupo controle 31 parturientes (62\%) fizeram uso de analgésicos durante a fase ativa.

Observamos que houve diferença estatisticamente significante $(p<0,001)$ entre o grupo tratamento e o controle (Figura 35).

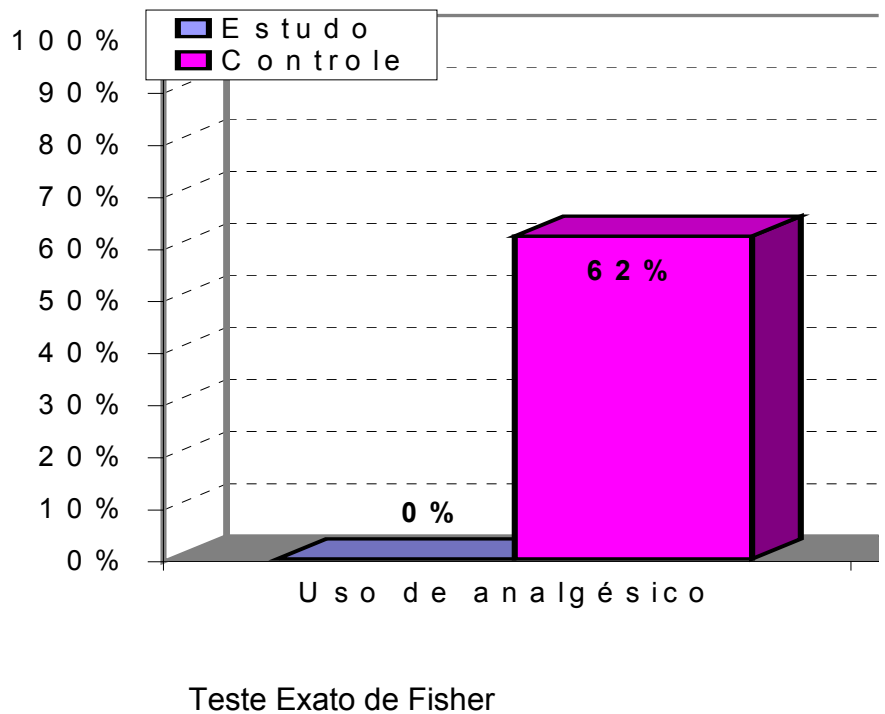

Figura 32: Distribuição entre os grupos do uso de analgésicos. $p<0,001$

\subsubsection{Uso de anestesia}

Em relação ao uso de anestesia para analgesia do parto, observouse que no grupo de estudo, seis parturientes (12\%) não fizeram uso de nenhuma anestesia, enquanto no grupo controle, todas as parturientes usaram alguma anestesia. 
Resultados

Anestesia local foi usada em 10 parturientes (20\%) no grupo de estudo e em 12 (22\%) no controle. Anestesia raquidiana, peridural ou duplo bloqueio, foi empregada em 34 parturientes (68\%) do grupo de estudo e em 38 parturientes ( $76 \%$ ) do controle (Figura 36).

Esses resultados demonstraram que houve diferença estatisticamente significante $(p<0,05)$ entre os grupos no uso da anestesia para analgesia de parto.

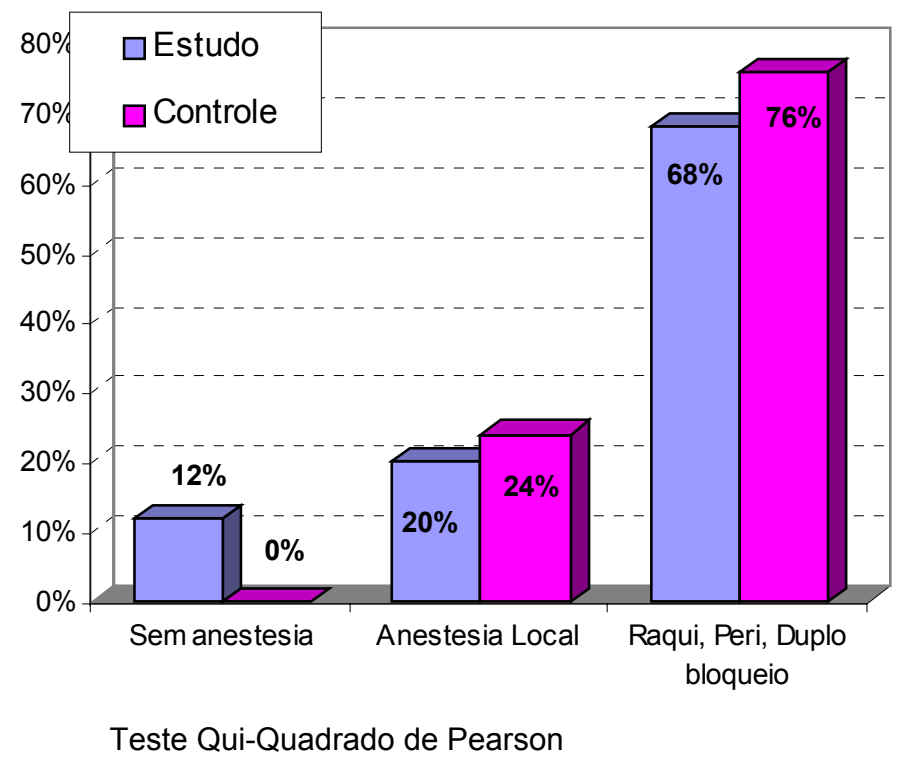

Figura 33: Distribuição entre os grupos do uso de anestesia. $\mathrm{p}<0,05$

\subsubsection{Uso de anestesia e dilatação cervical}

Analisamos também o uso de anestesia em relação a fase da dilatação cervical. 
Compararam-se os grupos de acordo com a fase da dilatação que foi usada anestesia: 7 ou $8 \mathrm{~cm}$ de dilatação e 9 ou10 cm

No grupo de estudo, seis parturientes (12\%) usaram analgesia para o parto entre 7 ou $8 \mathrm{~cm}$ de dilatação, enquanto que, no grupo controle 20 parturientes (40\%), o fizeram nessa fase da dilatação; no grupo de estudo 38 parturientes $(76 \%)$ usaram anestesia entre 9 ou $10 \mathrm{~cm}$ da dilatação, contra 30 parturientes $(60 \%)$ do grupo controle $(p<0,001)$.

Esses resultados mostraram que houve diferença estatisticamente significante entre os grupos em relação ao uso de anestesia e fase da dilatação em que foi usada.

No grupo de estudo as parturientes necessitaram de menos anestesia para analgesia do parto, usaram analgesia em fase mais tardia, isto é, com maior evolução da dilatação.

A tabela 7, a seguir mostra a comparação entre os grupos.

Tabela 7: Comparação entre os grupos no uso de anestesia e fase da dilatação.

\begin{tabular}{|c|c|c|c|c|c|}
\hline & & & \multicolumn{2}{|c|}{ Grupo } & \multirow[b]{2}{*}{ Total } \\
\hline & & & Tratamento & Controle & \\
\hline \multirow{6}{*}{$\begin{array}{l}\text { Cm de dilatação } \\
\text { na anestesia }\end{array}$} & 7 ou $8 \mathrm{~cm}$ & $\mathrm{~N}$ & 6 & 20 & 26 \\
\hline & & $\%$ & $12,0 \%$ & $40,0 \%$ & $26,0 \%$ \\
\hline & 9 ou $10 \mathrm{~cm}$ & $\mathrm{~N}$ & 38 & 30 & 68 \\
\hline & & $\%$ & $76,0 \%$ & $60,0 \%$ & $68,0 \%$ \\
\hline & S/ anestesia & $\mathrm{N}$ & 6 & & 6 \\
\hline & & $\%$ & $12,0 \%$ & & $6,0 \%$ \\
\hline \multirow[t]{2}{*}{ Total } & & $\mathrm{N}$ & 50 & 50 & 100 \\
\hline & & $\%$ & $100,0 \%$ & $100,0 \%$ & $100,0 \%$ \\
\hline
\end{tabular}




\subsubsection{8 Índices de Apgar}

Quanto aos índices de Apgar dos recém-nascidos, observou-se que no grupo de estudo não houve Apgar de primeiro minuto menor que sete.

A análise das medianas dos índices de primeiro, quinto e décimo minuto, não mostrou diferença estatisticamente significante entre os grupos.

A tabela 8 mostra os índices mínimos e máximos de cada grupo, e a comparação entre os grupos.

Tabela 8: Índices de Apgar dos recém-nascidos no grupo de estudo e no controle.

\begin{tabular}{ccccccc}
\hline \hline & Grupo & $\mathrm{N}$ & Mediana & Mínimo & Máximo & p-valor \\
\hline \multirow{2}{*}{ apgar } & Estudo & 50 & 9,00 & 7 & 10 & \\
$1^{\circ} \mathrm{min}$. & Controle & 50 & 9,00 & 3 & 10 & 0,091 \\
& Total & 100 & 9,00 & 3 & 10 & \\
\hline \multirow{2}{*}{ apgar } & Estudo & 50 & 9,00 & 8 & 10 & \\
$5^{\circ}$ min. & Controle & 50 & 9,00 & 7 & 10 & 0,405 \\
& Total & 100 & 9,00 & 7 & 10 & \\
\cline { 2 - 7 } apgar & Estudo & 50 & 10,00 & 9 & 10 & \\
$10^{\circ}$ min. & Controle & 50 & 10,00 & 8 & 10 & 0,954 \\
& Total & 100 & 10,00 & 8 & 10 &
\end{tabular}

Teste de Mann-Whitney 
Resultados

\subsection{Grupo de estudo 2}

Esse grupo refere-se às parturientes acompanhadas, que fizeram uso de ocitocina, devido à distocia funcional na evolução do trabalho de parto, por hipoatividade uterina.

A análise dos resultados foi feita comparativamente com grupo controle específico, isto é, parturientes que também usaram ocitocina.

O grupo de estudo e o controle foram submetidos inicialmente, a análise de homogeneidade, para posterior comparação.

Os resultados a seguir referem-se a 24 parturientes: 12 do grupo estudo e 12 do grupo controle.

\subsubsection{Análise de homogeneidade dos grupos}

A análise estatística da homogeneidade dos grupos de estudo e controle que usaram ocitocina, demonstrou que os mesmos foram homogêneos e, portanto, comparáveis.

As variáveis analisadas foram: idade materna, idade gestacional, etnia, escolaridade e peso dos recém-nascidos.

Em relação as variáveis quantitativas, idade materna e idade gestacional, tanto no grupo de estudo como no grupo controle, a média de idade foi de 20 anos, com mínima de 16 anos e máxima de 23 anos.

A mediana da idade gestacional foi de 39 semanas em ambos os grupos. 
A tabela 9 a seguir, mostra a comparação entre os grupos com respectivos desvios padrão, médias, medianas e p-valor.

Tabela 9: Descrição da homogeneidade dos grupos em relação a idade e idade gestacional.

\begin{tabular}{ccccccccc}
\hline \hline & Grupo & N & Média & Mediana & $\begin{array}{c}\text { Desvio } \\
\text { Padrão }\end{array}$ & Mínimo & Máximo & p-valor \\
\hline \hline \multirow{2}{*}{ Idade } & Estudo & 12 & 20,17 & 21,00 & 2,52 & 16 & 23 & \\
& Controle & 12 & 19,92 & 20,00 & 2,15 & 16 & 23 & 0,682 \\
& Total & 24 & 20,04 & 20,50 & 2,29 & 16 & 23 & \\
\hline \multirow{2}{*}{ IG } & Estudo & 12 & 39,17 & 39,00 & 0,94 & 37 & 40 & \\
\multirow{2}{*}{ semanas } & Controle & 12 & 39,08 & 39,00 & 0,90 & 37 & 40 & 0,754 \\
& Total & 24 & 39,13 & 39,00 & 0,90 & 37 & 40 & \\
\hline \hline
\end{tabular}

Teste de Mann-Whitney

Quanto a etnia, no grupo de estudo 10 parturientes (84\%) eram de cor branca, uma (8\%) de cor parda e uma (8\%) negra. No grupo controle seis parturientes eram brancas $(50 \%)$, quatro parturientes $(33 \%)$ de cor parda e duas $(17 \%)$ negras $(p=0,335)$. A figura 38 mostra a distribuição das etnias entre os grupos.

grupo de estudo

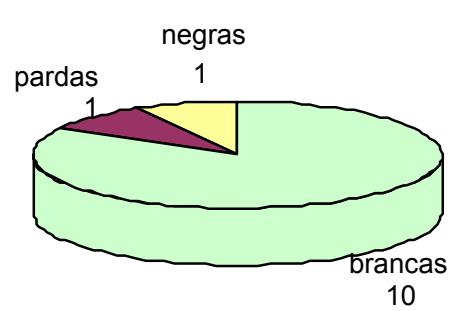

grupo controle

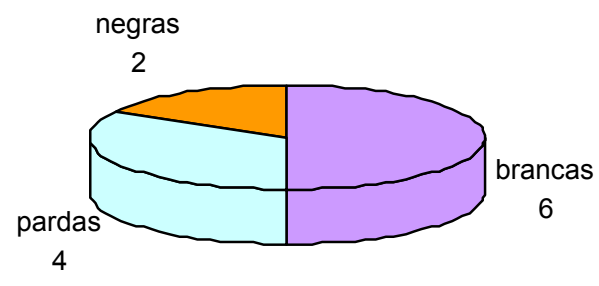

Figura 34: Comparação entre os grupos da distribuição das parturientes segundo as etnias. 
Em relação ao grau de escolaridade, os grupos também foram homogêneos $(p=0,426)$ e passíveis de comparação: não houve analfabetas em nenhum dos dois grupos; com nível de instrução elementar (ensino básico incompleto ou completo) foram sete parturientes (59\%) no grupo de estudo e cinco parturientes (41\%) no grupo controle; com grau de instrução mais elevado (ensino fundamental completo ou nível superior) foram cinco parturientes (41\%) no grupo de estudo e sete parturientes $(59 \%)$ no controle.

Em relação ao peso dos recém-nascidos, no grupo de estudo a média de peso foi de $3232 \mathrm{~g}$, variando entre $2670 \mathrm{~g}$ e $3745 \mathrm{~g}(+/-357,28)$; no grupo controle a média foi de $3248 \mathrm{~g}$, variando entre $2730 \mathrm{~g}$ e $3760 \mathrm{~g}$ (+/- 355,91). A comparação desses resultados mostrou que, não houve diferença estatisticamente significante entre os grupos, em relação ao peso dos recém-nascidos.

A seguir estão descritos os resultados das variáveis de desfecho.

\subsubsection{Análise das variáveis de desfecho}

As variáveis de desfecho consideradas foram: tipo de parto, a duração da fase ativa, o início e duração do uso de ocitocina, uso de analgésicos, uso de anestesia, peso dos recém-nascidos e índices de Apgar. 
Resultados

\subsubsection{Tipo de parto}

Em ambos os grupos só ocorreram partos vaginais; a indicação de fórcipe, para abreviar o período expulsivo, foi semelhante nos dois grupos: no grupo estudo, em sete parturientes (58\%) e no grupo controle em oito parturientes (67\%). Não houve diferença significativa entre os grupos em relação ao uso do fórcipe no parto vaginal $(p>0,05)$.

Observou-se maior presença de distocia de rotação, no grupo controle: seis partos contra dois do grupo de estudo (Figura 38).

grupo de estudo

parto fórcipe-

distocia

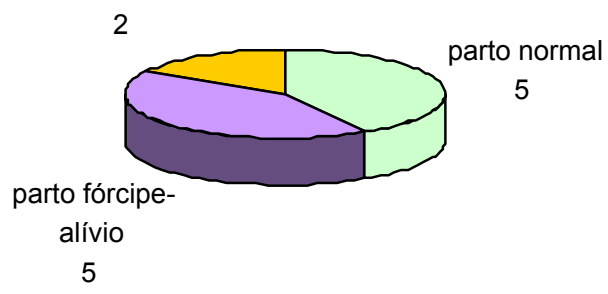

grupo controle

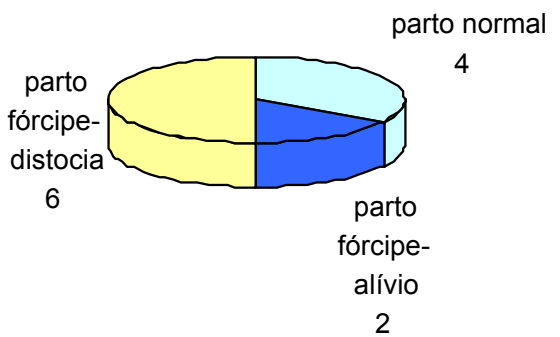

Figura 35: Distribuição entre os grupos segundo o tipo de parto

\subsubsection{Duração da fase ativa do trabalho de parto}

No grupo de estudo a média de duração da fase ativa foi de 6h54min (+/- 1,50), com variação entre 4 e 9 horas. No grupo controle a média de duração da fase ativa foi de $11 \mathrm{~h}(+/-6,15)$, com variação entre 4 e 24 horas $(p=0,059)$. 
Resultados

A mediana da duração da fase ativa foi de $7 \mathrm{~h}$ no grupo tratamento e de 9h no grupo controle e a condição da bolsa amniótica foi semelhante nos dois grupos; apresentavam bolsa íntegra no início da fase ativa, oito parturientes no grupo de estudo e nove no controle; tinham bolsa rota quatro parturientes no grupo de estudo e três no controle.

Esses resultados mostram uma tendência estatística na diferença da duração da fase ativa entre os grupos, caso o número de sujeitos estudados fosse maior e não houvesse uma variação tão ampla na duração da fase ativa no grupo controle (Tabela 10).

Tabela 10: Comparação entre os grupos em relação à duração da fase ativa.

\begin{tabular}{lllllllll}
\hline \hline & Grupo & N & Média & Mediana & $\begin{array}{c}\text { Desvio } \\
\text { Padrão }\end{array}$ & Mínimo & Máximo & p-valor \\
\hline \hline & Estudo & 12 & 6,54 & 7,00 & 1,50 & 4 & 9 & \\
$\begin{array}{c}\text { Fase ativa } \\
\text { (horas) }\end{array}$ & Controle & 12 & 11,00 & 9,00 & 6,15 & 4 & 24 & 0,059 \\
& Total & 24 & 8,77 & 7,00 & 4,94 & 4 & 24 & \\
& & & & & & & & \\
\hline
\end{tabular}

Teste de Mann-Whitney

\subsubsection{Início e duração do uso de ocitocina}

Foi analisado o início do uso da ocitocina em relação à fase da dilatação e o tempo que a parturiente ficou sob infusão, até a dilatação total.

A dose inicial de ocitocina foi de $2 \mathrm{mUl} / \mathrm{min}$ (4gotas/min), aumentando $2 \mathrm{~m} \mathrm{UI}$ a cada 15 minutos, em ambos os grupos. 
No grupo de estudo a mediana em relação à fase de dilatação em que foi iniciada a ocitocina, foi de $4 \mathrm{~cm}$, com variação entre 4 e $7 \mathrm{~cm} \mathrm{(+/-}$ 1,00); no grupo controle, a mediana também foi de $4 \mathrm{~cm}$, mas a variação foi entre 3 e $4 \mathrm{~cm} \quad(+/-\quad 0,51)$ de dilatação. Observou-se diferença estatisticamente significante entre os grupos, em relação à fase da dilatação em que foi iniciada a ocitocina $(p=0,003)$. No grupo controle todas as parturientes iniciaram ocitocina aos $3-4 \mathrm{~cm}$ de dilatação cervical, ao passo que no grupo de estudo a infusão de ocitócico iniciou-se, em média, com dilatação maior (até de $7 \mathrm{~cm}$ ); nenhuma parturiente iniciou a infusão aos $3 \mathrm{~cm}$ de dilatação. A Figura 39 mostra a comparação entre os grupos.

Em relação ao tempo que a parturiente ficou com ocitocina, observou-se que no grupo de estudo as parturientes permaneceram, em média, 4h 38min com a infusão (+/-1,49), com variação entre 2 e 6 horas; no grupo controle, a média foi de 8 h58min $(+/-3,45)$, com variação entre 4 e 16 horas $(p=0,001)$. No grupo de estudo o período com infusão de ocitocina foi menor (Figura 40).

Esses resultados mostraram que houve diferença estatisticamente significante entre os grupos, em relação ao início e duração do uso de ocitocina $(p<0,05)$.

Verificou-se, que o grupo de estudo iniciou mais tardiamente o uso de ocitocina e durante menos tempo (Figuras 39 e 40). 
Resultados

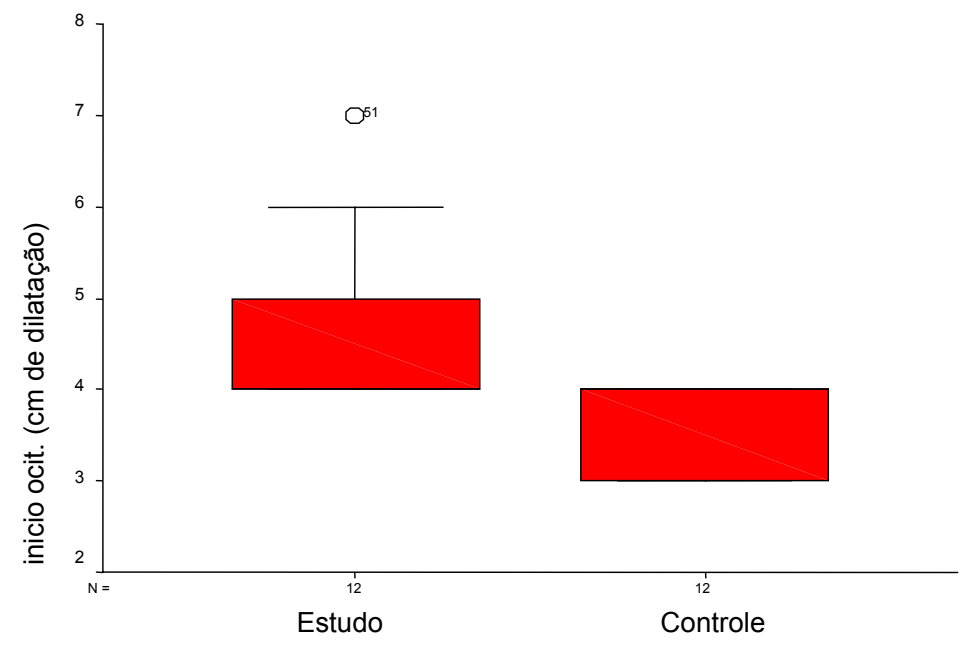

Teste Mann-Whitney

Figura 36: Comparação entre os grupos do início da ocitocina em relação a fase da dilatação.

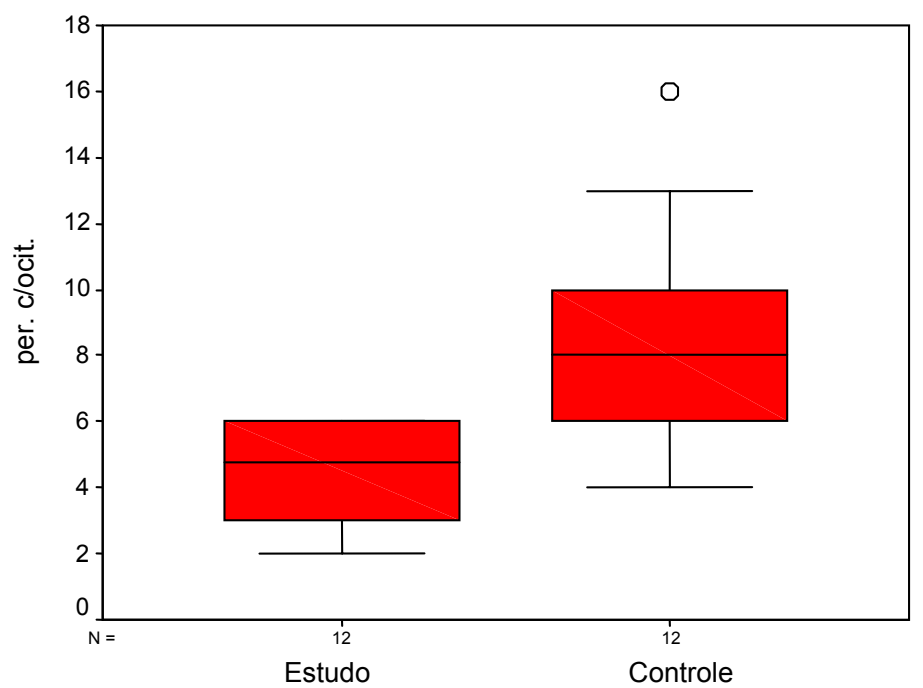

Teste Mann-Whitney

Figura 37: Comparação entre os grupos do período com ocitocina. 


\subsubsection{Uso de analgésicos}

No grupo de estudo, nenhuma parturiente fez uso de analgésicos (meperidina ou buscopan), durante a fase ativa, enquanto no grupo controle, 10 parturientes (83\%) fizeram uso de fármacos para analgesia da dor durante a fase ativa.

Observamos que houve diferença estatisticamente significante $(p<0,001)$ entre os grupos no uso de analgésicos. Mesmo com uso de ocitocina, o grupo estudo não necessitou de medicação analgésica para alívio da dor.

\subsubsection{Uso de anestesia}

Quanto ao uso de anestesia para analgesia de parto, observou-se que no grupo de estudo duas parturientes (17\%) não necessitaram de nenhuma anestesia, enquanto que no grupo controle, todas as parturientes usaram alguma anestesia. Anestesia local foi usada por uma parturiente (8\%) do grupo de estudo e por quatro parturientes do grupo controle. Anestesia raquidiana, peridural ou duplo bloqueio, foi usada em nove parturientes (75\%) do grupo de estudo e em oito parturientes (67\%) do controle (Figura 41).

Esses resultados mostraram que não houve diferença significante entre os grupos, no uso de anestesia para o parto $(p=0,172)$. 
Resultados

uso de anestesia

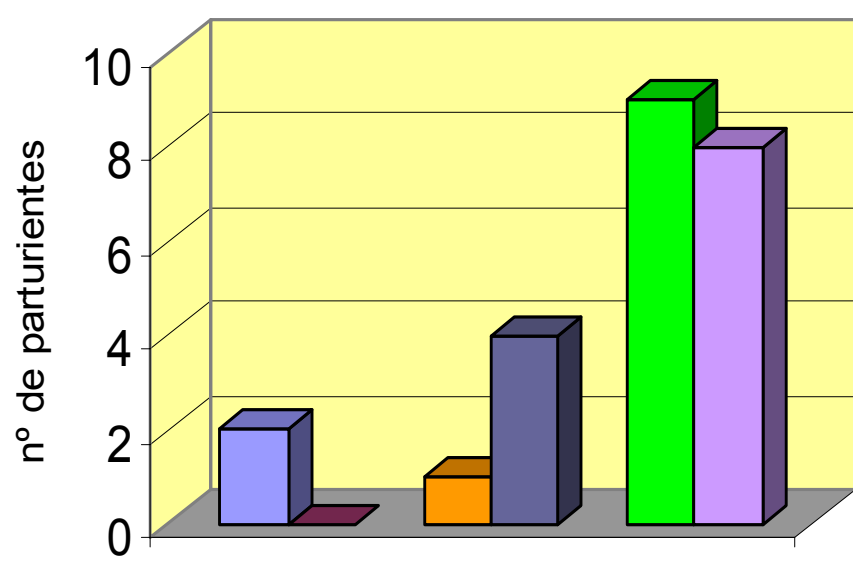

$\square$ sem anestesia/estudo

$\square$ controle

$\square$ anest. local/estudo

$\square$ controle

口 raqui; peri; duplo/estudo

u controle

Figura 38: Comparação entre os grupos em relação ao uso de anestesia.

\subsubsection{7 Índices de Apgar}

Quanto aos índices de Apgar dos recém-nascidos, observou-se que no grupo de estudo não houve Apgar de primeiro minuto menor que 8 . A análise das medianas dos índices de primeiro, quinto e décimo minuto, não mostrou diferença estatisticamente significante entre os grupos.

A tabela 11 mostra com detalhes a comparação entre os grupos. 
Tabela 11: Comparação dos grupos em relação aos índices de Apgar.

\begin{tabular}{clllccc}
\hline \hline & Grupo & $\mathrm{N}$ & Mediana & Mínimo & Máximo & p-valor \\
\hline \hline & Estudo & 12 & 9,00 & 8 & 10 & \\
$\begin{array}{c}\text { Apgar } \\
1^{\circ} \mathrm{min} .\end{array}$ & Controle & 12 & 8,00 & 6 & 9 & 0,092 \\
& Total & 24 & 8,00 & 6 & 10 & \\
\hline & Estudo & 12 & 9,50 & 9 & 10 & \\
Apgar & Controle & 12 & 9,00 & 8 & 10 & 0,342 \\
$5^{\circ}$ min. & Total & 24 & 9,00 & 8 & 10 & \\
\hline & Estudo & 12 & 10,00 & 9 & 10 & $>0,999$ \\
Apgar & Controle & 12 & 10,00 & 9 & 10 & \\
$10^{\circ}$ min. & Total & 24 & 10,00 & 9 & 10 &
\end{tabular}

Teste de Mann-Whitney

\subsection{Grupo de estudo 3}

Fazem parte desse grupo as parturientes acompanhadas que evoluíram para parto cesárea. Foram oito parturientes, o que corresponde a $11 \%$ da amostra estudada.

As causas de indicação de cesárea foram:

a) distocia funcional, por parada da dilatação cervical $(n=3)$, hipoatividade uterina $(n=2)$ e parada na descida $(n=1)$;

b) desproporção céfalo-pélvica $(n=1)$;

c) sofrimento fetal intraparto $(n=1)$;

Esse grupo não foi comparado com grupo controle e será objeto de análise na discussão. Porém são apresentados a seguir, os partogramas da evolução do trabalho dessas parturientes (Figuras 39 a 46) 


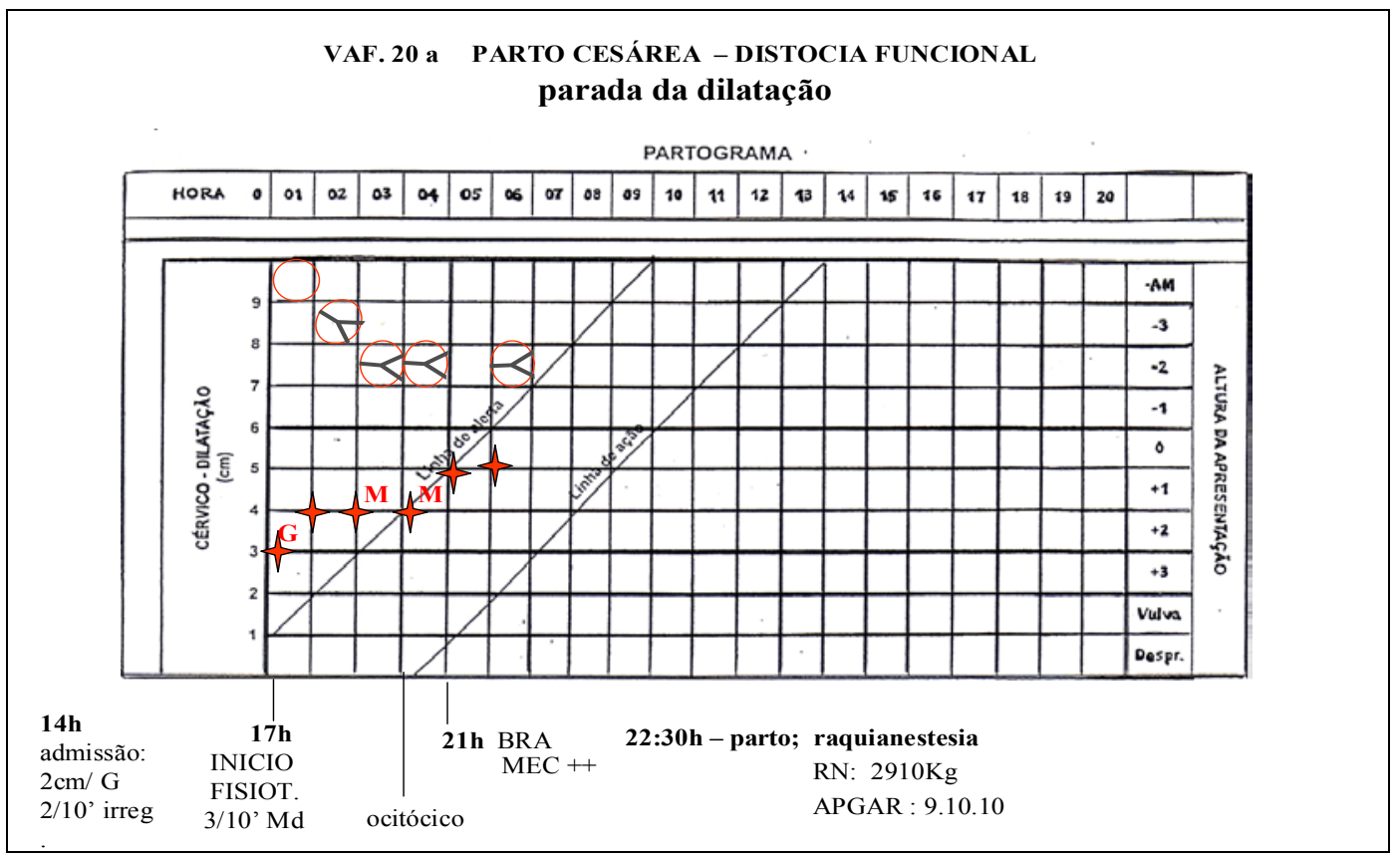

Figura 39: Registro da progressão da dilatação, da dinâmica das contrações e da descida fetal, na fase ativa do trabalho de parto.

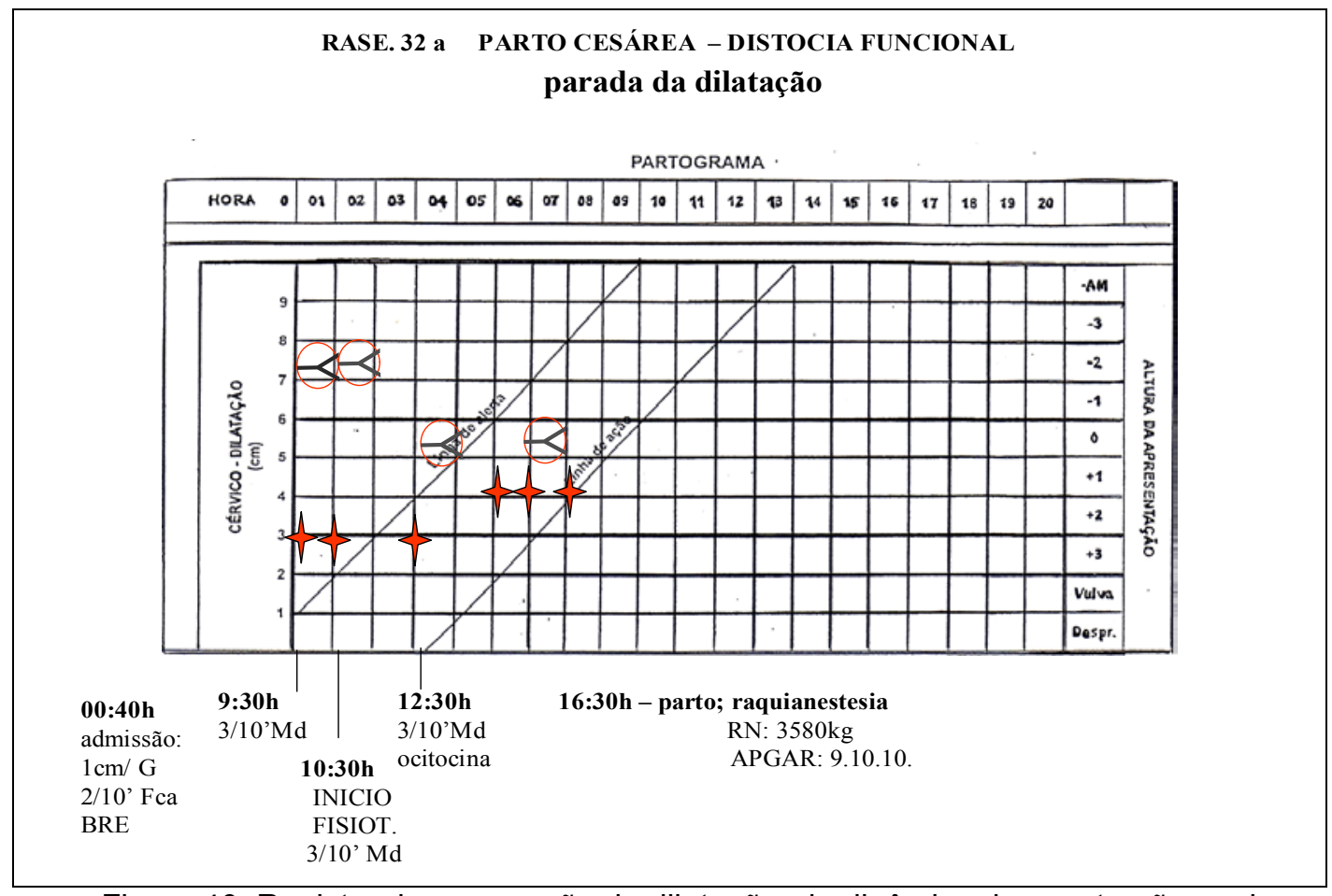

Figura 40: Registro da progressão da dilatação, da dinâmica das contrações e da descida fetal, na fase ativa do trabalho de parto. 


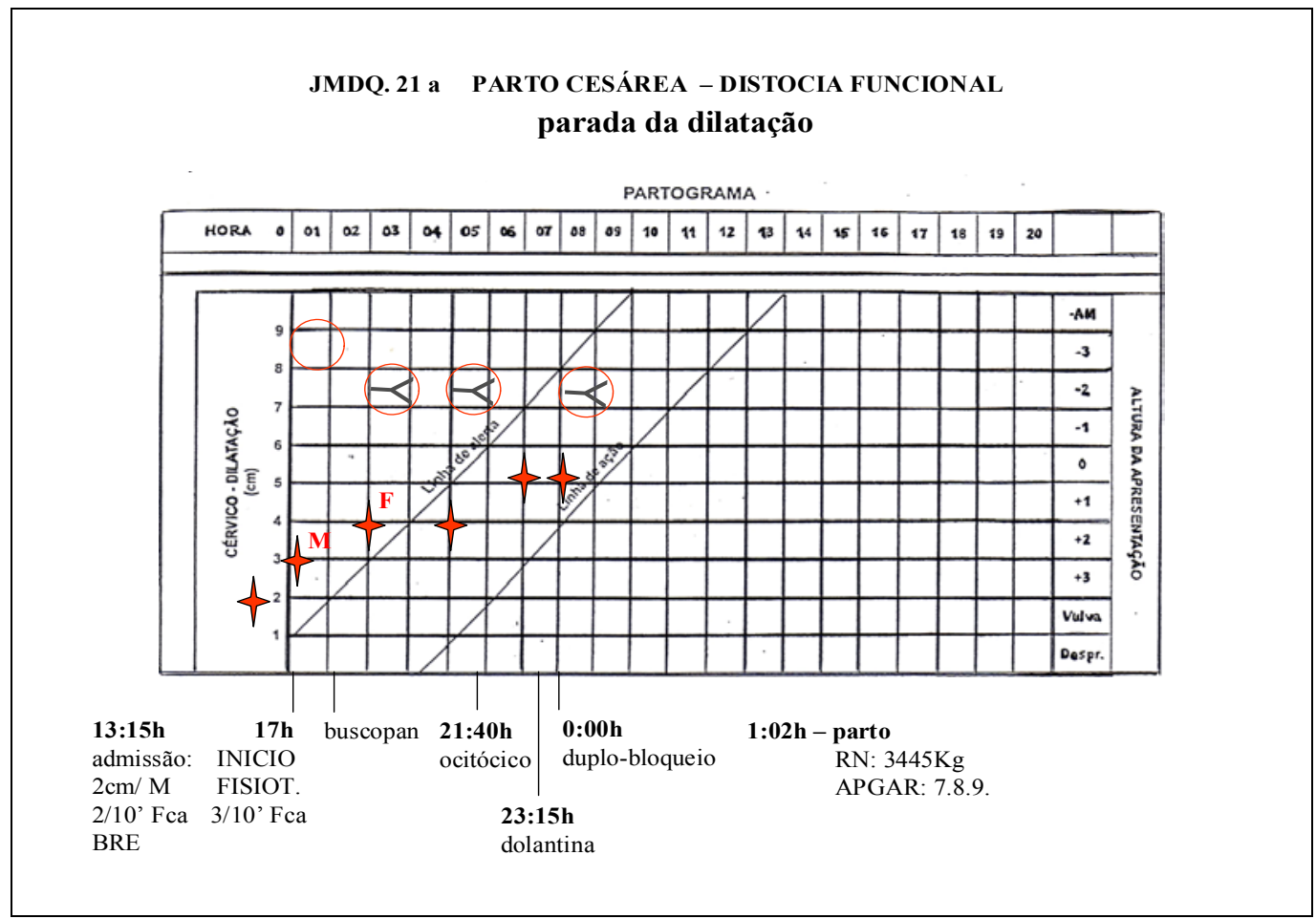

Figura 41: Registro da progressão da dilatação, da dinâmica das contrações e da descida fetal, na fase ativa do trabalho de parto.

MCMS. 20 a PARTO CESÁREA - DISTOCIA FUNCIONAL hipoatividade uterina primária

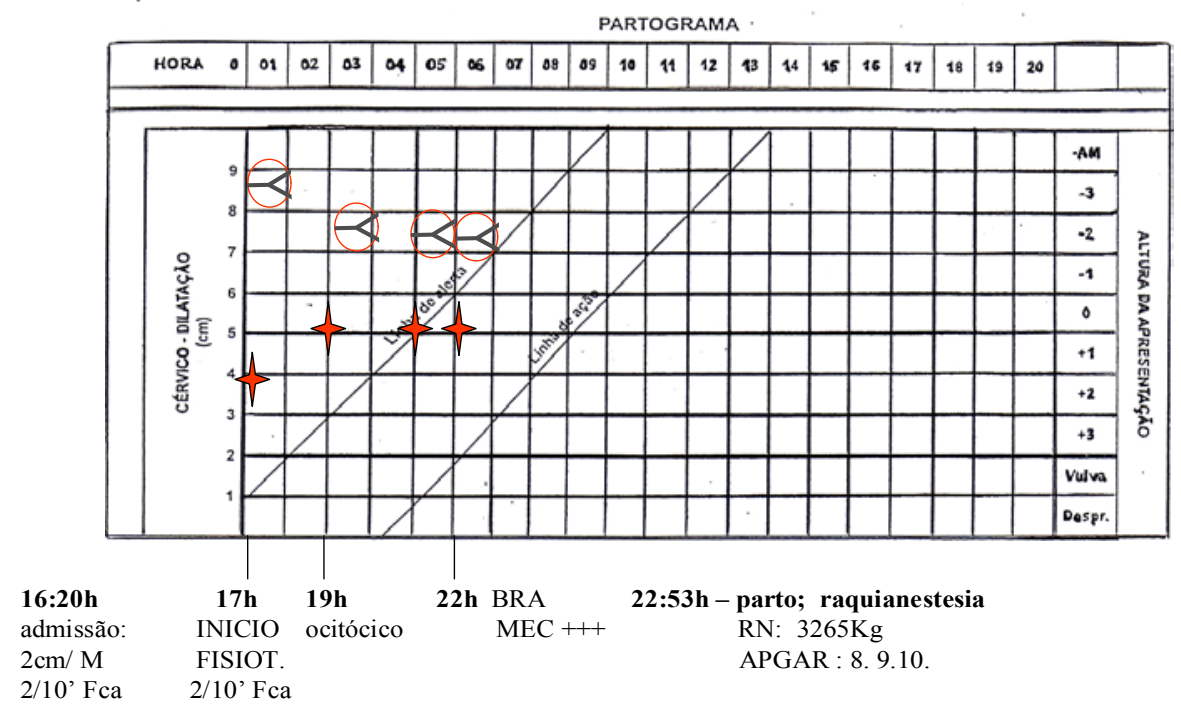

Figura 42: Registro da progressão da dilatação, da dinâmica das contrações e da descida fetal, na fase ativa do trabalho de parto. 


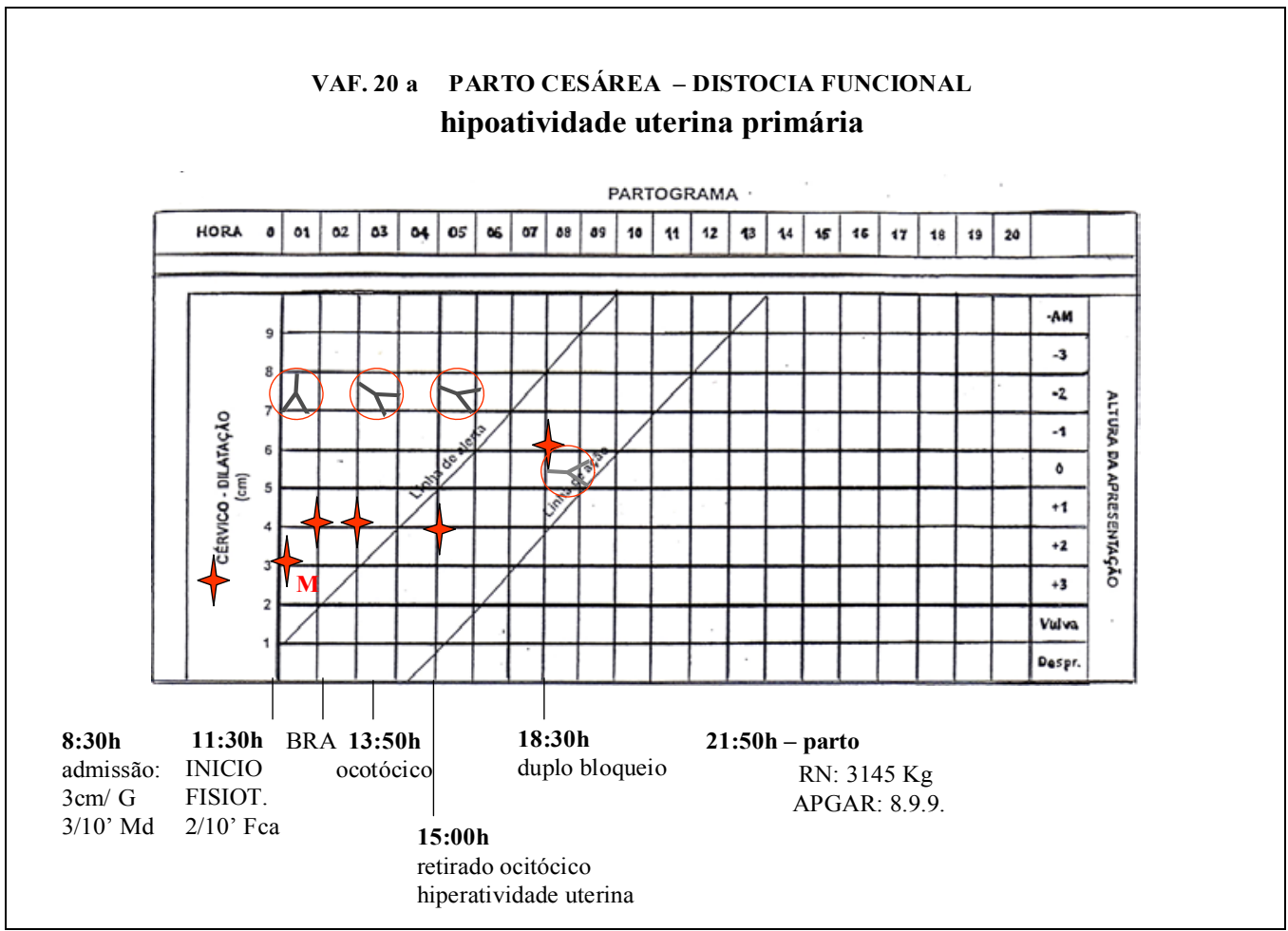

Figura 43: Registro da progressão da dilatação, da dinâmica das contrações e da descida fetal, na fase ativa do trabalho de parto.

KAS. 25 a PARTO CESÁREA - DISTOCIA FUNCIONAL parada na descida

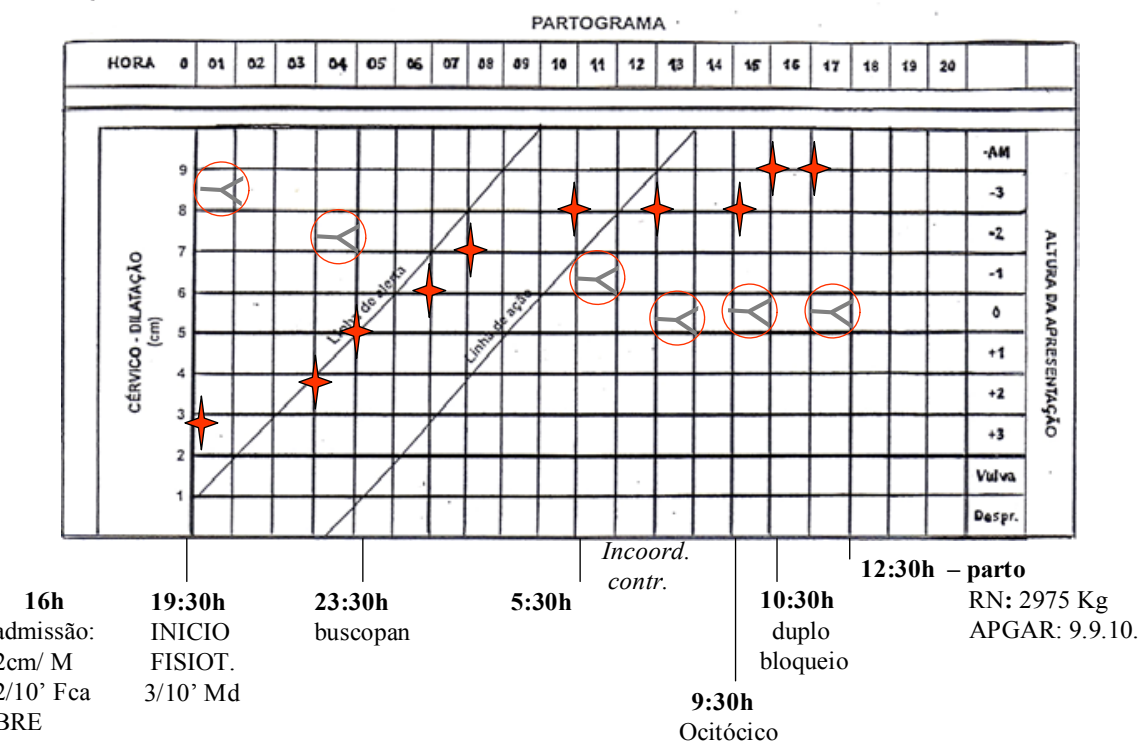

Figura 44: Registro da progressão da dilatação, da dinâmica das contrações e da descida fetal, na fase ativa do trabalho de parto.

$G=$ colo grosso; $M=$ colo médio; $F=$ colo fino;

$B R E=$ bolsa rota espontaneamente; $B R A=$ Bolsa rota artificialmente;

$F c a=$ contração de intensidade fraca; $M d=$ contração de intensidade média; 


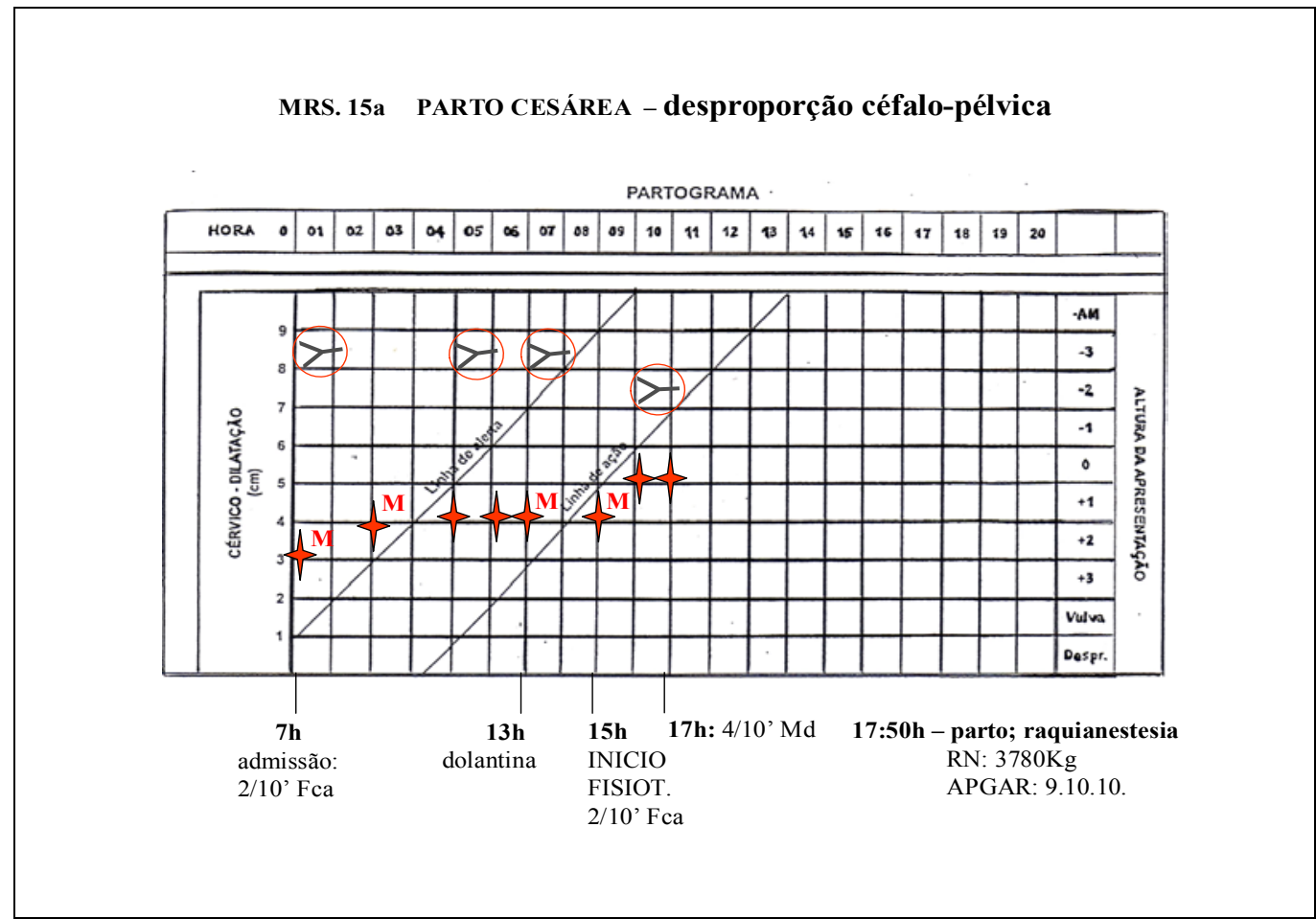

Figura 45: Registro da progressão da dilatação, da dinâmica das contrações e da descida fetal, na fase ativa do trabalho de parto.

MJS. 21 a PARTO CESÁREA - sofrimento fetal

PARTOGRAMA

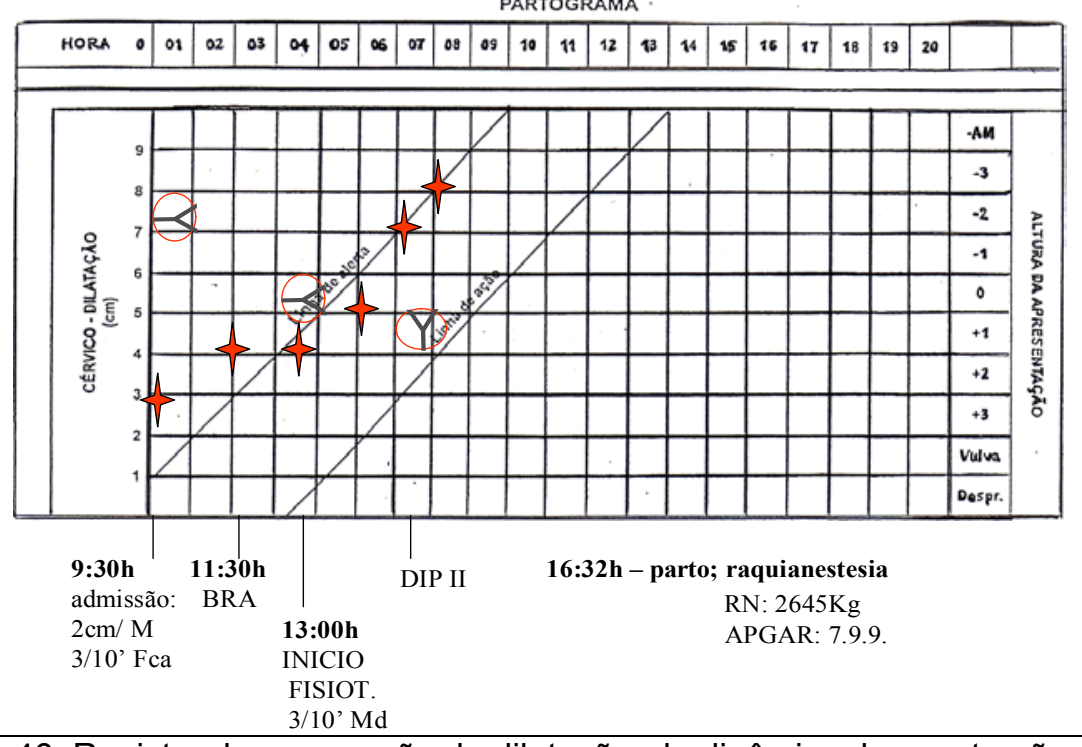

Figura 46: Registro da progressão da dilatação, da dinâmica das contrações e da descida fetal, na fase ativa do trabalho de parto.

$M=$ colo médio; $F=$ colo fino;

$B R A=$ Bolsa rota artificialmente;

Fca = contração de intensidade fraca; $M d=$ contração de intensidade média; 
6. DISCUSSÃO 
A ação do fisioterapeuta na assistência ao trabalho de parto nos leva a discutir, primeiramente, a importância da preparação e do incentivo para o parto vaginal e o valor de uma postura ativa e consciente da parturiente.

À primeira vista, pode parecer antigo e não necessário, defender o parto vaginal, propor que a parturiente se assegure da sua potência de gestar e dar à luz, se aproprie do conhecimento de seu corpo e de sua fisiologia, torne-se ativa no trabalho de parto.

A crença na ciência e seus poderes, característica da modernidade, a expansão das tecnociências e da farmacologia, têm imprimido à assistência ao parto um caráter cada vez menos natural, gerando a suspeita de incompetência da mulher para enfrentar o parto com os próprios recursos ${ }^{77}$.

$\mathrm{Na}$ assistência ao parto, os valores da modernidade e o conceito de atualidade precisam ser ampliados para além da dimensão temporal. Temse tratado o atual como sinônimo da experiência presente e o não-atual como algo do passado, isto é, ultrapassado e desnecessário ${ }^{3}$.

Deixou de ser atual a parturiente se movimentar durante o trabalho de parto, saber como usar conscientemente seu corpo para o parto vaginal, o que não quer dizer que não seja necessário fazê-lo. Discutir se a intervenção da fisioterapia no trabalho de parto é necessária, é pensar que o não-atual pode ser um novo conhecimento ou uma possibilidade que pode despontar para melhorar a assistência ao parto. 
Nessa perspectiva, estamos nos referindo à importância do parto vaginal como via de eleição para o nascimento.

Apesar da concepção patológica que se tem tentado criar sobre a fisiologia do parto vaginal, incentivando a "epidemia de cesáreas" da atualidade, há, paralelamente, uma tendência mundial ao resgate do parto vaginal. Os estudos em nosso meio mostram que o parto vaginal tem sido valorizado por muitas camadas sociais, como processo natural, como parte da experiência da mulher para "tornar-se mãe", como vivência importante no desenvolvimento da genitalidade e como exercício de independência, significativo para o psiquismo da mulher ${ }^{1,13,15,78,79,80}$.

Entretanto, não basta ter preferência pelo parto vaginal, pois o trabalho de parto exige a estrutura psicossomática da mulher e por isso é necessário que ela se prepare durante a gestação e receba um acompanhamento especial.

Sabemos que a escolha da via de parto é determinada por parâmetros clínico-obstétricos como atividade uterina, avaliação da bacia, vitalidade fetal, entre outros, que se entrecruzam com outras variáveis, também determinantes, como nível sócio-econômico-educacional, características psicológicas, desenvolvimento emocional, particularidades culturais, representações sociais e ética profissional. A compreensão desses fatores implica em conhecimento multidisciplinar, torna a preparação e a assistência ao parto multiprofissional, porém com atribuições de responsabilidade e risco, que devem ser divididas entre o profissional e a paciente ${ }^{81}$. 
A intervenção fisioterapêutica na assistência ao parto junto à equipe obstétrica valoriza a responsabilidade da parturiente no processo, por meio do uso ativo do próprio corpo. Manter o corpo em movimento no trabalho de parto envolve a interação de fatores fisiológicos, psicológicos, culturais e principalmente, o apoio e orientação da equipe obstétrica. Neste sentido, a ação do fisioterapeuta é um fator de estímulo para que a parturiente ganhe consciência de que seu corpo ativo pode ser um poderoso instrumento para facilitar o processo do trabalho de parto e trazer-lhe satisfação com a experiência do nascimento.

A partir do século XVIII, a cultura assimilou gradativamente o parto em posição horizontal e parece que a influência se estendeu para o trabalho de parto. As parturientes são orientadas a permanecerem no leito e se movimentam muito pouco. Apenas uma porcentagem muito pequena de mulheres escolhe, espontaneamente, a deambulação ou alguma posição vertical durante o trabalho de parto. Porém, os estudos mostram que, se são autorizadas, orientadas e encorajadas, experimentam e preferem andar ou ficar em pé, mudam várias vezes de posição,conforme a evolução da dilatação, numa mobilização natural durante o trabalho de parto ${ }^{19,82}$. Foi o que pudemos observar em nosso estudo, onde todas as parturientes concordaram em ser acompanhadas, aceitaram as orientações e nenhuma desistiu de se manter em movimento durante todo o trabalho de parto.

As amostras populacionais estudadas, de mulheres de diferentes culturas, sul-americanas, européias, canadenses, norte-americanas, japonesas, demonstram que os resultados decorrentes da mobilidade da 
parturiente em posições verticais independem da etnia. Apesar da avaliação da bacia ser um dos indicadores de prognóstico para o parto vaginal, os conhecimentos atuais vêm mostrando que a arquitetura da pelve óssea é determinada além da raça, pelo uso e modo de viver ${ }^{70,83}$. Em nosso estudo, não verificamos entre as mulheres brasileiras negras, pardas e maioria branca, diferenças na forma e mobilidade pélvica.

Em relação à idade materna, não são referidas contra-indicações para as posições verticais e mobilidade da parturiente, pois as posturas verticais não se constituem em prática invasiva e, ao contrário da posição supina, não têm efeito compressivo sobre a veia cava, melhoram a ventilação pulmonar, facilitam a excursão diafragmática e levam à redução no uso de fármacos durante o trabalho de parto ${ }^{11,16,63,84}$. Na população pesquisada, o grupo de estudo e o grupo controle apresentaram faixa etária entre 15 e 37 anos (média de 21 anos) e não observamos intercorrências relativas à idade materna. No grupo de estudo não verificamos restrições à independência motora decorrentes da idade da parturiente, mas foi respeitada a história escrita em cada corpo e o grau de consciência corporal possível em cada idade cronológica e emocional.

A amostra pesquisada, de nível sócio-econômico médio e baixo, apresentou nível de escolaridade variável com predominância do grau de instrução fundamental. Os estudos indicam que o nível de instrução da parturiente determina, em grande parte, as representações sociais ligadas ao parto, construídas em cada rede sócio-cultural, gerando crenças e valores em relação ao corpo grávido e ao trabalho de parto, que emergem 
Discussão

durante a assistência ${ }^{85,86,87}$. Esse foi um aspecto valorizado no acompanhamento, isto é, os saberes não-técnicos das parturientes, o nível de informação, a linguagem própria de cada uma se referir ao corpo, dentro do seu grau de instrução. É em primeiro lugar, uma barreira lingüística que dificulta a relação terapêutica, com as diferenças léxicas (das palavras e termos) e sintática (construção das frases) da expressão verbal das classes populares e de nós profissionais da saúde ${ }^{88}$. Como as parturientes foram orientadas em trabalho de parto, sem acompanhamento prévio durante a gravidez, era fundamental usar recursos que agilizassem a interação terapêutica. Sendo o objetivo da presença do fisioterapeuta o uso ativo, voluntário e consciente do corpo, a linguagem empregada para esse fim, foi determinante para alcançar a ação eficiente do corpo e os resultados conquistados. A linguagem foi intencionalmente usada com fins terapêuticos, criando uma ponte lingüística capaz de criar uma comunicação ressonante com o universo de representações corporais da parturiente para que surgisse o movimento voluntário e bem estruturado.

A revisão da literatura mostrou que, nas últimas quatro décadas, muitos estudos têm se ocupado em discutir e redefinir a postura e a autonomia da parturiente e alguns serviços têm tentado implementar mudanças na orientação à parturiente, humanizando a assistência hospitalar.

Os estudos das décadas de 70 e 80 que, como Caldeyro-Barcia (1960), usaram a metodologia com catéter intra-útero e transdutor, para medir a atividade uterina em posição horizontal e em posição vertical, 
demonstraram que as posturas verticais (sentada, em pé, andando) aumentam a intensidade e a freqüência das contrações, favorecem o tríplice gradiente descendente da contração uterina, geram menos irregularidades no ritmo das contrações, aumentam a pressão do pólo cefálico sobre o colo uterino, levando à diminuição do período de fase ativa ${ }^{28-35}$.

As confirmações introduzidas por um pesquisador de ponta da fisiologia obstétrica, como foi Caldeyro-Barcia, deveriam ter sido suficientes para a mudança na postura materna e no modelo da assistência ao parto.

Observamos em nosso estudo que a tendência a manter a parturiente no leito persiste, que existem grandes resistências por parte da equipe obstétrica e grandes dificuldades por parte das parturientes para aceitar e manter um comportamento ativo durante o trabalho de parto

O fato é que o corpo livre e em movimento durante o trabalho de parto, com mobilização da pelve, alternando várias posições verticais (deambulação, sentar, em pé, cócoras), acelera a atividade uterina e reduz o período de fase ativa, como demonstram muitos estudos clínicos no mundo, desde os anos 70 até hoje ${ }^{29,30,37,38,41,45,66}$. Pudemos verificar em nosso estudo os mesmos resultados: as parturientes estimuladas a se movimentarem em posturas verticais em coordenação motora e com posturas específicas para cada fase da dilatação, tiveram um período de fase ativa menor. Discutimos que diminuir a duração da fase ativa, não deve ser o único objetivo da intervenção fisioterapêutica, na medida que o processo de trabalho de parto envolve variáveis e intercorrências imprevistas. Mesmo sabendo que, fisiologicamente, esse processo não pode ser rápido, também não se deseja 
que seja muito longo, para não aumentar fatores de estresse sobre a mãe e o feto. Assim é que, se levarmos em conta que nas parturientes que se mantiveram em movimento e em posturas verticais, a média da duração da fase ativa de 5horas, foi menor do que entre as parturientes do grupo controle que permaneceram sem mobilidade e em posições horizontais (9horas), podemos deduzir os ganhos que a intervenção promoveu.

Em nosso meio, até o momento, não há nenhum estudo baseado em evidência, que demonstre resultados positivos entre a mobilidade da parturiente e diminuição da fase ativa, o que sugere que não há domínio dessa prática entre nós.

Apesar de nossa metodologia incluir somente parturientes em início de fase ativa (colo apagado, dilatação cervical de $3-4 \mathrm{~cm}$ e dinâmica uterina de 3 contrações/10 minutos), e a maioria (66\%) estar com a bolsa íntegra, 34\% das parturientes estavam com bolsa rota no início do acompanhamento. Como sabemos que a rotura prematura das membranas é um fator que pode acelerar a fase ativa trabalho de parto ${ }^{89}$, analisamos a influência dessa variável nos resultados dos grupos de estudo e controle. As parturientes com bolsa íntegra no início do acompanhamento, apresentaram em média $5 \mathrm{~h}$ de fase ativa e as que estavam com bolsa rota $4 \mathrm{~h} 29 \mathrm{~min}$, ao passo que no grupo controle, nas parturientes com bolsa íntegra a média de duração da fase ativa foi de $8 \mathrm{~h} 23 \mathrm{~min}$ e com bolsa rota foi $7 \mathrm{~h}$.

Segundo estudo realizado por Albuquerque (1993) ${ }^{90}$, a população de baixo risco do Hospital Universitário, apresenta de 8 a 11horas de duração da fase ativa. Os nossos dados mostram que a duração da fase ativa foi 
menor no grupo acompanhado (4 a 5 horas) e considerando a condição da bolsa das águas, a diferença entre o grupo de estudo e controle, se manteve.

A comparação desses achados ajuda a esclarecer que é possível diminuir a duração da fase ativa do trabalho de parto, por meio do uso adequado do corpo.

Outra variável que julgamos importante especificar foi o esvaecimento do colo. Foi interessante observar que no grupo das parturientes acompanhadas, aquelas que iniciaram a fisioterapia com colo fino, como era de se esperar, tiveram menos tempo de fase ativa (4h). Porém, o mesmo não aconteceu no grupo controle, onde a duração da fase ativa foi de 7horas, mesmo nas parturientes com colo fino. Observamos que a diferença entre o grupo de estudo e o controle, na duração da fase ativa também se manteve independente da condição de esvaecimento do colo. Observamos que a partir do afinamento do colo, a mobilização da parturiente surte um grande efeito na progressão da dilatação.

Consideramos que não é só a mobilização corporal aleatória e posições verticais escolhidas arbitrariamente que asseguram atividade uterina, dilatação cervical e diminuição da fase ativa. Não basta que a parturiente permaneça em posição vertical se ação da musculatura estriada, não recebe ordens neurais voluntárias. É possível que esse seja um dos fatores pelos quais a mobilidade na vertical, não foi completamente estabelecida como conduta para o trabalho de parto. A diferença em nosso estudo foi orientar as parturientes na ação consciente da musculatura 
estriada, tanto na mobilidade geral como na ação funcional da pelve e nas posturas verticais, criando condições sensório-motoras de coordenação e não manter simplesmente a parturiente em posição vertical.

Nas parturientes com fase ativa protraída foi prescrita ocitocina para condução das contrações, porém quando comparamos a duração da fase ativa com o grupo controle, pudemos observar que nas parturientes que se mantiveram em movimento houve maior aceleração das contrações e da dilatação resultando em: menos tempo com infusão de ocitocina (4h38min), quando comparadas com grupo controle (8h58min), a média da duração da fase ativa foi menor no grupo de estudo (6h54min) do que no controle (11h). É importante salientar que inúmeros estudos demonstram que a movimentação da parturiente em posições verticais, tornam as contrações mais regulares e mais eficientes, o que reduz a indicação de ocitocina para condução do trabalho de parto ${ }^{38,53,59,61,66}$.

Em paralelo aos fatores neuro-hormonais que perturbam o ritmo das contrações, do ponto de vista corporal foi interessante observar que as parturientes que apresentaram evolução lenta da dilatação, hipoatividade uterina e necessidade de ocitocina foram, as que mostraram dificuldade com a mobilidade pélvica e as posturas verticais, limitações osteomusculares, inversão do gradiente descendente e resistências para perceber o corpo. Porém, na medida que o ocitócico tornava as contrações mais intensas, foi possível tornar esse efeito um recurso de sensibilização, para a percepção corporal, para mobilizar a pelve e para conseguir a ação de relaxamento do períneo, que resultou nos melhores resultados descritos. 
Quanto mais consciência corporal a parturiente já tem ou pode desenvolver durante a sensibilização que o trabalho de parto impõe, melhor é o comportamento motor. O bom uso da musculatura estriada depende da percepção sensorial para a estruturação do movimento coordenado. É nesse ponto que se encontra a diferença entre movimentos aleatórios, que não modificam a estrutura postural e o movimento coordenado pela consciência corporal. A postura vertical em incoordenação motora, com tensão pélvica ou rigidez articular, não traz conforto para a parturiente e ela vai preferir o decúbito dorsal ou lateral, o que, a nosso ver, explica os resultados negativos encontrados em alguns estudos ${ }^{36,39,40,50,56,83}$. Entre as dificuldades relatadas por esses autores, registra-se a resistência das parturientes em manterem-se sentadas ou andando, depois dos $6 \mathrm{~cm}$ de dilatação; porém não observamos esse comportamento em nosso estudo.

O que foi possível ainda analisar a partir dos resultados é que a mobilidade e as posturas verticais, também tiveram efeito na analgesia. Como nós, a maioria dos estudos refere que as parturientes se queixam menos de dor quando assumem posições verticais ${ }^{16,30,37,45,57,58,63}$. No grupo acompanhado, as parturientes não fizeram uso de analgésicos, o que demonstra que a tolerância à dor aumentou. No grupo controle houve necessidade de indicação de meperidina e outros fármacos, para alívio da dor durante a fase ativa.

O manejo da dor exige que o limiar e o limite de tolerância individual sejam avaliados, porém, o nosso objetivo não foi prioritariamente eliminar a sensação da contração uterina, que varia entre desconforto e variáveis 
Discussão

percepções de dor. Consideramos que a aceleração das contrações uterinas, o peso fetal na pelve, a pressão no períneo, a abertura dos diâmetros da bacia e a dilatação cervical, responsáveis por percepções desagradáveis ao longo do processo de trabalho de parto, são recursos de informação sensorial para a parturiente direcionar o uso do corpo e podem ser minimizadas pela postura em coordenação. Para algumas mulheres essas sensações são insuportáveis; outras entendem a dor ou o desconforto das contrações uterinas, como algo inerente ao processo de parturição, sendo parte da experiência da mulher que quer ser mãe ${ }^{91}$.

As posições verticais, como já foi demonstrado, aumentam a pressão no colo uterino durante e nos intervalos das contrações, o que sem dúvida, é um componente que pode se traduzir em dor ${ }^{33,34,35}$. As parturientes acompanhadas relataram a percepção desse aumento de pressão na pequena bacia, nas diversas posições verticais usadas. Conseqüentemente, a percepção da pelve e, principalmente do períneo, ficavam altamente sensibilizadas, surgindo muitas particularidades nas percepções das parturientes. Duas reações recorrentes merecem discussão: $1^{\circ}$ ) a sensação de pressão perineal assusta, aumenta o medo e gera uma reação de contração muscular contrária à dilatação, irrita as terminações nervosas da pelve e da musculatura do períneo, aumentando a sensação de dor; $2^{\circ}$ ) a sensação do volume do feto no canal vaginal representa um registro novo na região genital feminina (antes do primeiro parto), pois a percepção corporal da fisiologia feminina se dá na receptividade da região vaginal e não na ação muscular de deixar dilatar para a passagem fetal. Essas percepções 
emergem somente no contexto do trabalho de parto, tomando tanto a dimensão física como a dimensão emocional da mulher e exigem aprendizados.

Para suportar a pressão perineal intensa, a partir do plano de Lee +1 e +2, principalmente nas posições verticais, as parturientes acompanhadas foram orientadas em como não lutar contra a sensação de peso e pressão (dilatação e a descida fetal), por meio da mobilização ativa da pelve, concentrada nos pequenos movimentos articulares das sacro-ilíacas, lombosacra, coxofemurais e no apoio móvel do púbis. Tal procedimento inibe a força contrátil do períneo, facilitando a capacidade de elasticidade de suas fibras, relaxa a musculatura da pelve gerando menos dor. Considerando que não medimos a percepção de dor das parturientes acompanhadas, podemos deduzir que o fato do grupo de estudo não ter feito uso de analgésicos indica que houve maior tolerância à dor, quando comparamos com o grupo controle.

É importante que a parturiente sinta e suporte a pressão no períneo, pois, quando a percepção da contração não migra para o períneo, principalmente em posições verticais, permanecendo no abdome ou na região lombar, temos um sinal de distocia de trabalho de parto ${ }^{92,93}$.

Atualmente, a dor intensa durante o trabalho de parto, pode ser evitada pelo uso da analgesia peridural, raquianestesia ou duplo bloqueio, que constituem um efetivo alívio para as parturientes. Por outro lado, a revisão sistemática da Biblioteca Cochrane demonstra que o uso prematuro ou em alta dose da anestesia peridural e duplo bloqueio se associam ao 
aumento de risco para o parto fórcipe ${ }^{94,95}$. Os estudos mais recentes mostram que, quando administradas em pequena dosagem, permitem que a motricidade se mantenha e que a parturiente possa se movimentar ${ }^{96}$.

Em nosso estudo, observamos que o uso do corpo em movimento e na verticalidade evitou ou adiou o uso da anestesia. Discutimos dois resultados que nos parecem importantes: no grupo de estudo $12 \%$ das parturientes não precisou de anestesia para o parto, ao passo que no grupo controle todas as parturientes fizeram uso de alguma anestesia; no grupo de estudo uma porcentagem maior de parturientes (76\%) fez uso da anestesia com a dilatação mais adiantada $(9-10 \mathrm{~cm})$. Esses resultados nos possibilitam inferir que a mobilidade da parturiente, especialmente o uso coordenado e consciente da pelve, funcionou como recurso de analgesia. Estudos demonstram que as parturientes que se movimentam em posições verticais durante o trabalho de parto solicitam menos analgesia e anestesia para o parto ${ }^{38,47,59,61,66}$. Os nossos resultados sofrem influência da rotina obstétrica do Hospital Universitário, onde todas as parturientes recebem analgesia para o parto, se assim o desejarem. Porém, discutimos que fazer uso da anestesia com a dilatação cervical mais adiantada ou no período expulsivo, como ocorreu com grande porcentagem das parturientes do grupo de estudo, gera mais consciência da região do períneo e permite que o esforço da expulsão seja melhor dirigido.

A percepção e o enfrentamento da dor durante o trabalho de parto, são determinadas pelas características subjetivas de cada parturiente mas são influenciada pelo ambiente hospitalar e pelo suporte emocional que a 
parturiente recebe. É possível que os resultados positivos da intervenção fisioterapêutica possam ser interpretados como decorrentes da função da fisioterapeuta como acompanhante, isto é, ser um suporte emocional para a parturiente e não pela ação da mobilidade corporal e pelas posturas em coordenação.

Sabe-se que o suporte emocional que é dado à parturiente pela equipe obstétrica e pela presença de um acompanhante de sua escolha, interfere na evolução do trabalho de parto ${ }^{97,98}$. Porém, a presença de um acompanhante, mesmo que escolhido pela parturiente (como lhe assegura a lei), por si só não pode ser considerado como sinônimo de suporte. Os efeitos benéficos de um suporte emocional contínuo dependem da qualidade da relação interpessoal estabelecida entre os agentes envolvidos na situação ${ }^{97,99}$.

Salientamos que tanto no grupo de estudo como no grupo controle, as parturientes tiveram direito a seu acompanhante. Esse procedimento da rotina do Hospital Universitário poderia ter influenciado os resultados do grupo controle, nas variáveis de desfecho analisadas, o que não ocorreu. A diferença na comparação dos resultados dos grupos de estudo e controle, se dirige para a resposta à mobilidade corporal diferenciada para cada estágio da fase ativa do trabalho de parto; a presença e ação do fisioterapeuta estão voltadas para ajudar a parturiente a operar seus próprios recursos e prover o estímulo constante para que ela se mantenha ativa, o que se diferencia das atribuições do chamado acompanhante de parto. 
Não desconsideramos a importância e os efeitos da presença contínua da fisioterapeuta, sabendo que em toda ação terapêutica há sempre um encontro interpessoal que passa pela linguagem e pela natureza compreensiva e construtiva do diálogo mediado pela técnica ${ }^{7}$. Mas defendemos que a metodologia aplicada é passível de ser reproduzida com a objetividade da técnica, sem desconsiderar que o êxito técnico não esteve desvinculado da relação de confiança estabelecida na interação com a parturiente.

Nas parturientes acompanhadas, a mobilidade pélvica alterou a relação funcional entre contração uterina, descida fetal e a dilatação cervical. Os nossos resultados sugerem que a intervenção fisioterapêutica realizada nessa população facilitou o parto vaginal.

Em nossa amostra, a incidência de cesárea foi de $11 \%$ e de parto vaginal foi de $89 \%$, sugerindo que a intervenção contribuiu para esses resultados. Entre os partos vaginais, houve uma menor incidência de partos com fórcipe no grupo de estudo (50\%), do que no grupo controle $(62 \%)$, indicando a repercussão da mobilidade corporal no período expulsivo; é preciso considerar que se trata de uma maternidade escola, onde a indicação do fórcipe, mesmo de alívio, tem caráter didático.

Por se tratar de uma amostra de primigestas, a experiência com o corpo em trabalho de parto era inédita e desconhecida; consideramos que ao favorecer a percepção do corpo como meio de aprendizado desse processo, resultou na porcentagem pequena de cesarianas. 
Entretanto, a hipoatividade uterina mostrou ser fator limitante para a eficácia das posições verticais e da mobilidade. Foi o que pudemos observar nas parturientes que evoluíram para cesárea; admite-se que a movimentação da parturiente auxilia a dinâmica uterina mas por si só, não gera contração eficiente para dilatação cervical. Por isso, indicar a deambulação para desencadear a atividade uterina, como está descrito em muitos estudos, nem sempre funciona; andar e se movimentar pode gerar contração uterina por excitabilidade da musculatura, mas nem sempre são contrações de atividade uterina eficiente.

Durante o trabalho de parto, a posição vertical, somada à mobilidade da parturiente e a pressão do pólo cefálico, são efeitos potenciais para mudança da amplitude pélvica, facilitando o parto vaginal ${ }^{84}$. Em nossos dados, verificamos que a abertura dos diâmetros pélvicos, por meio da mobilidade articular e da verticalidade, favoreceu a maior incidência de partos vaginais. Os estudos de pelvimetria por ressonância magnética (em não-grávidas), contribuem para a constatação de que as posições verticais influenciam a dimensão dos diâmetros pélvicos. As imagens da pelve em posição horizontal e em posição vertical (de joelhos e de cócoras), mostram que a medida do diâmetro biciático aumenta 6 a $7 \mathrm{~mm}$ nas posições verticais; o diâmetro biisquiático aumenta $5 \mathrm{~mm}$ em posição de cócoras em relação à posição horizontal ${ }^{100}$. Tais achados demostram que os diâmetros da bacia sofrem influência da posição corporal. Além disso, nas posições verticais a contração dos músculos do assoalho pélvico é menos intensa, o que responde melhor às exigências da dilatação cervical e elasticidade do 
períneo necessárias para o parto vaginal ${ }^{101}$. Por isso, as posições verticais surtem mais efeito na evolução da dilatação e na descida fetal do que as posições horizontais, desde que a pelve esteja móvel.

O que foi possível constatar nas parturientes acompanhadas é que a adaptação osteomuscular da pelve conseguida durante o trabalho de parto, influenciou o comportamento do períneo, facilitando o parto vaginal. Para o trabalho de parto não importa avaliar o períneo como assoalho, mas o mais importante é equilibrar a base pélvica como suporte ósseo do períneo, para assegurar a adaptabilidade elástica desejada.

Além disso, observamos pelos índices de Apgar que, os recémnascidos tiveram boas condições de nascimento, demonstrando que a intervenção não gerou efeitos adversos no feto.

Assim é que, resgatar procedimentos simples com o corpo, como as posturas verticais e a movimentação da parturiente, oferece vantagens pouco exploradas no nosso meio na assistência ao trabalho de parto: as posições verticais em coordenação tornam mais eficientes as contrações uterinas, o que conseqüentemente, acelera a dilatação; a mobilidade pélvica amplia os diâmetros da bacia facilitando o trajeto da descida fetal, como os resultados encontrados nos permitem analisar.

Concordamos com Kelly et al. ${ }^{52}$ (1999), que não há uma única posição vertical a ser orientada à parturiente, mas podemos dizer que a mudança postural ao longo do trabalho de parto e o menor tempo possível em posições horizontais (decúbito dorsal e lateral), facilitam o trabalho de parto para o parto vaginal. 
Em suma, nossos dados, a exemplo dos estudos mais recentes, chamam a atenção para a redescoberta das posturas verticais e da liberdade de movimento da parturiente como práticas baseada em evidência na segurança materno-fetal, eficácia na prevenção de complicações e morbidade materna, eficientes para reduzir o período de fase ativa ${ }^{11,16,64,65}$.

Acreditamos ter demonstrado que os recursos da técnica e do método dessa intervenção podem ser aplicados na assistência ao trabalho de parto, mesmo que a parturiente não tenha sido preparada no pré-natal.

Além da vantagem assistencial, tais procedimentos também podem trazer benefícios para o ensino médico, para aprimorar o acompanhamento à parturiente.

Os nossos achados nos permitem sugerir que assistir a parturiente para manter o corpo móvel, ajudar a coordenar a ação da musculatura estriada, oferecer movimentos funcionais para cada fase da dilatação são orientações essenciais que, devem ser introduzidas na assistência ao trabalho de parto. 
O presente estudo que avalia a intervenção fisioterapêutica na assistência ao trabalho de parto, permite concluir que:

1) a ação na estrutura osteomuscular facilita a progressão do trabalho de parto;

2) a mobilidade pélvica promove a evolução da dilatação;

3) o uso consciente do corpo favorece o parto vaginal. 
ANEXO A

\section{น}

hospital universitário universidade de são paulo

São Paulo, 26 de março de 2002.

$\mathrm{Il}^{\mathrm{mo}(\mathrm{a})} \cdot \mathrm{S}^{\mathrm{r}(\mathrm{a})}$

Eliane Rodrigues Bio

Rua Francisco Leitão, 97 - apto. 102

Pinheiros

05414-020 São Paulo - SP

Referente: Projeto de Pesquisa "Proposta de intervenção fisioterapêutica na assistência ao parto" - Cadastro: 258/02

Prezado(a) Senhor(a)

O Comitê de Ética em Pesquisa do Hospital Universitário da Universidade de São Paulo, em reunião de 22 de março de 2002, analisou o projeto de pesquisa acima citado, considerando-o como APROVADO, assim como o Termo de Consentimento PósInformado.

Lembramos que cabe ao pesquisador elaborar e apresentar a este Comitê, relatórios parciais (a cada 90 dias) e final sobre a pesquisa (Resolução do Conselho Nacional de Saúde 196 de 10-10-1996, inciso IX, letra "c").

O primeiro relatório do referido projeto está previsto para 22 de junho de 2002.

Atenciosamente,

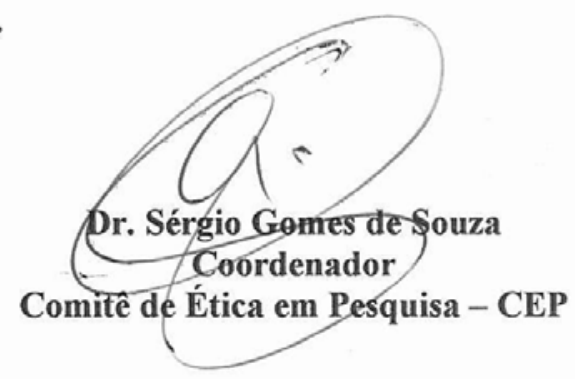

c/cónia nara a Divisão de Clínica Obstétrica 


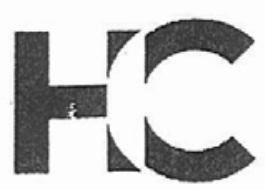

ANEXO B

DIRETORIA CLÍNICA

Comissão de Ética para Análise de Projetos de Pesquisa

\section{APROVACÃO}

A Comissão de Ética para Análise de Projetos de Pesquisa - CAPPesq da Diretoria Clínica do Hospital das Clínicas e da Faculdade de Medicina da Universidade de São Paulo, em sessão de 08.09.04, APROVOU o Protocolo de Pesquisa $n^{\circ}$ 411/04, intitulado: "Avaliação da influência de intervenções fisioterapêuticas no trabalho de parto" apresentado pelo Departamento de OBSTETRÍCIA E GINECOLOGIA, inclusive 0 Termo de Consentimento Livre e Esclarecido.

Pesquisador(a) Responsável: Prof. Dr. Roberto Eduardo Bittar

Pesquisador(a) Executante: Sra. Eliane Rodrigues Bio

CAPPesq, 08 de Setembro de 2004.

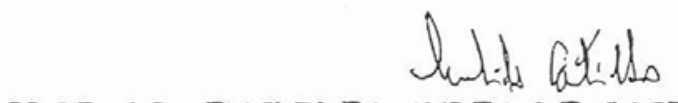

PROF. DR. EUCLIDES AYRES DE CASTILHO

Presidente da Comissão de Ética para Análise de Projetos de Pesquisa

OBSERVAÇÃO: Cabe ao pesquisador elaborar e apresentar à CAPPesq, os relatórios parciais e final sobre a pesquisa (Resolução do Conselho Nacional de Saúde $n^{\circ} 196$, de 10.10.1996, inciso IX.2, letra "c") 


\author{
HOSPITAL DAS CLÍNICAS \\ da Faculdade de Medicina da Universidade de SÃo PaUlo \\ CaIXa Postal, 8091 - SÃo PAUlo - BRAsIL
}

ANEXO C

TERMO DE CONSENTIMENTO LIVRE E ESCLARECIDO

\title{
I - DADOS DE IDENTIFICAÇÃO DO SUJEITO DA PESQUISA OU RESPONSÁVEL LEGAL
}

1. NOME DO PACIENTE .

DOCUMENTO DE IDENTIDADE $\mathrm{N}^{\circ}$ :

SEXO : .M $F$

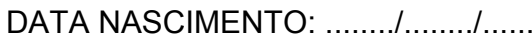

ENDEREÇO

BAIRRO:

CEP:.

TELEFONE: DDD

CIDADE

APTO:

2.RESPONSÁVEL LEGAL

NATUREZA (grau de parentesco, tutor, curador etc.)

DOCUMENTO DE IDENTIDADE :

SEXO: $M \quad F$

DATA NASCIMENTO.: ....................

ENDEREÇO:

BAIRRO:

$\mathrm{N}^{\circ}$

APTO:

CEP:

TELEFONE: DDD (

CIDADE:

\section{II - DADOS SOBRE A PESQUISA CIENTÍFICA}

1. TÍTULO DO PROTOCOLO DE PESQUISA

AVALIAÇÃO DA INFLUÊNCIA DE INTERVENÇÕES FISIOTERAPÊUTICAS NO TRABALHO DE PARTO

PESQUISADOR: ELIANE RODRIGUES BIO

CARGO/FUNÇÃO: FISIOTERAPEUTA INSCRIÇÃO CONSELHO REGIONAL No 640-F

UNIDADE DO HCFMUSP: CLIINICA OBSTÉTRICA

3. AVALIAÇÃO DO RISCO DA PESQUISA:

$\begin{array}{ll}\text { SEM RISCO } & \text { RISCO MÍNIMO X RISCO MÉDIO } \\ \text { RISCO BAIXO } & \text { RISCO MAIOR }\end{array}$

(probabilidade de que o indivíduo sofra algum dano como consequência imediata ou tardia do estudo)

4.DURAÇÃO DA PESQUISA : DOIS ANOS 
III - REGISTRO DAS EXPLICAÇÕES DO PESQUISADOR AO PACIENTE OU SEU REPRESENTANTE LEGAL SOBRE A PESQUISA CONSIGNANDO:

Quero convidá-la para fazer parte do meu projeto de pesquisa sobre a influência do acompanhamento da fisioterapia durante o trabalho de parto.

É uma pesquisa para estudar a influência de exercícios de fisioterapia durante o trabalho de parto. Caso concorde em ser acompanhada, acompanharei todo o trabalho de parto até o nascimento do bebê, propondo que você faça exercícios de pé, sentada e andando, durante os intervalos das contrações, exercícios de respiaração durante e depois das contrações e posições de relaxamento. Pretendemos, com sua ajuda, demonstrar que esses exercícios podem aliviar a dor da contração uterina, encurtar o período de trabalho de parto, trazer mais conforto e facilitar o parto.

Esclareço que esses procedimentos não oferecem nenhum risco a sua integridade física, nem a saúde do seu bebê; esses exercícios visam trazer benefícios no sentido de reduzir o tempo do trabalho de parto e torná-lo mais eficiente e com menos dor.

\section{IV - ESCLARECIMENTOS DADOS PELO PESQUISADOR SOBRE GARANTIAS DO SUJEITO DA PESQUISA CONSIGNANDO:}

1. acesso, a qualquer tempo, às informações sobre procedimentos, riscos e benefícios relacionados à pesquisa, inclusive para dirimir eventuais dúvidas.

2. liberdade de retirar seu consentimento a qualquer momento e de deixar de participar do estudo, sem que isto traga prejuízo à continuidade da assistência.

3. salvaguarda da confidencialidade, sigilo e privacidade.

4. disponibilidade de assistência no HCFMUSP, por eventuais danos à saúde, decorrentes da pesquisa.

5. viabilidade de indenização por eventuais danos à saúde decorrentes da pesquisa.

\section{INFORMAÇÕES DE NOMES, ENDEREÇOS E TELEFONES DOS RESPONSÁVEIS PELO ACOMPANHAMENTO DA PESQUISA, PARA CONTATO EM CASO DE INTERCORRÊNCIAS CLÍNICAS E REAÇÕES ADVERSAS.}

Eliane Rodrigues Bio

Rua Joaquim Antunes - 767 - conj 34

Tel: $30863151 \quad$ Cel: 99908748

VI. OBSERVAÇÕES COMPLEMENTARES:

\section{VII - CONSENTIMENTO PÓS-ESCLARECIDO}

Declaro que, após convenientemente esclarecido pelo pesquisador e ter entendido o que me foi explicado, consinto em participar do presente Protocolo de Pesquisa

São Paulo, de de 19 . 


\section{ANEXO D}

\section{ACOMPANHAMENTO FISIOTERAPÊUTICO DO TRABALHO DE PARTO}

nome:

idade:

escolaridade:

estado conjugal:

endereço:

$\mathrm{RH}$ profissão :

ENTRADA NO PRÉ-PARTO: EM Às

IDADE GESTACIONAL: $\quad 37^{\mathrm{a}}$ sem. $\quad 38^{\mathrm{a}} \quad 39^{\mathrm{a}} \quad 40^{\mathrm{a}} \quad 41^{\mathrm{a}} \quad 42^{\mathrm{a}} \mathrm{sem}$.

ULTRASONOGRAFIA : 1 na

2 na

3 ou mais

sem esse dado

SINAIS DE TRABALHO DE PARTO: BOLSA ROTA HÁ CONTRAÇÕES

DILATAÇÃO

DOR EM BAIXO VENTRE

EXAME OBSTÉTRICO :

DADOS CLÍNICOS:

ESTADO GERAL :

PRÉ-NATAL: NÃO SIM/LOCAL

INTERCORRÊNCIAS NA GRAVIDEZ: 
INICIO DO ACOMPANHAMENTO FISIOTERAPÊUTICO: ÀS HORAS

PROCEDIMENTOS REALIZADOS: EXAME GINECOLÓGICO

TRICOTOMIA

ENEMA

ULTRA-SOM

MONITORAGEM

OUTROS

CONTATO INICIAL COM A PACIENTE:

. DISPONÍVEL PARA O CONTATO

. NÃO DISPONÍVEL

. ATIVA . PASSIVA

.ALERTA . AUSENTE

$\begin{array}{lll}\text {.INIBIDA .RESERVADA .PERTURBADA } & \end{array}$

. EM POSIÇÃO DE: Decúbito dorsal

Decúbito lateral: esquerdo direito

Sentada

Andando

Outra

DINÂMICA DE TRABALHO DE PARTO:

DILATAÇÃO

CONTRAÇÕES fracas médias fortes

BOLSA : ÍNTEGRA ROTA

Observações: 
EVOLUÇÃO:

1. Registros do exame de toque vaginal, evolução da dilatação cervical e descida do pólo cefálico

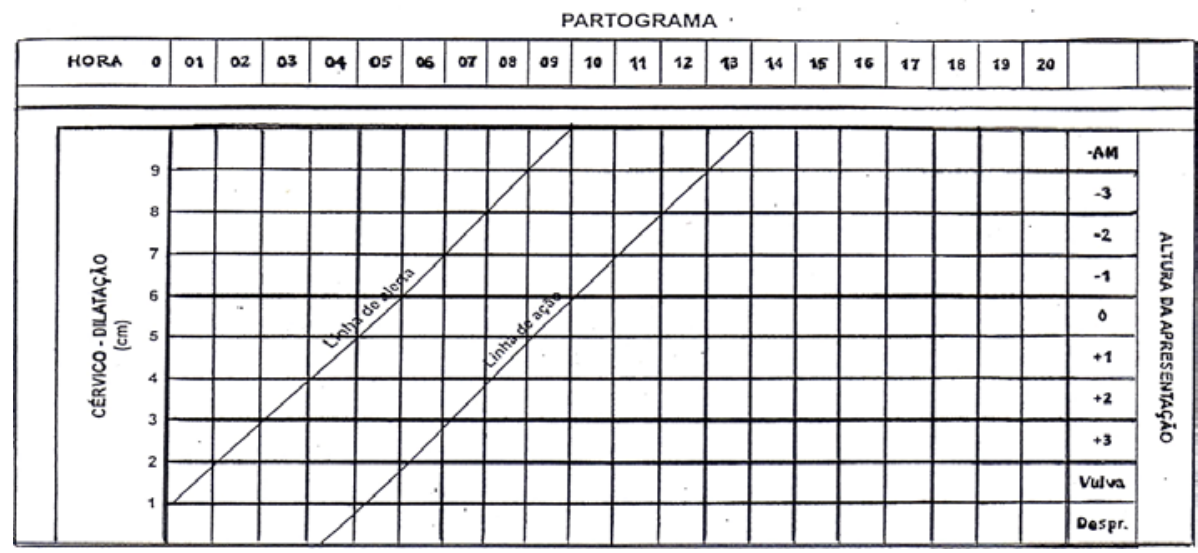

2. Seqüência dos procedimentos fisioterapêuticos aplicados e avaliação psicomotora:

3. Registro das queixas; falas e relatos da parturiente: 
9. REFERÊNCIAS 
1. Diniz CSG. Humanização da assistência ao parto no Brasil: os muitos sentidos de um movimento. Ciência \&Saúde Coletiva. 2005; 10(3): 62737

2. Bezerra MGA, Cardoso VLC. Fatores culturais que interferem nas experiências das mulheres durante o trabalho de parto e parto. Rev. Latino-am Enfermagem. 2006; 14(3):414-21.

3. Mesquita Ayres JR de C. Necessidade, objetividade e o paradoxo metafísico do conhecimento. História, Ciência, Saúde - Manguinhos. 1995; II (1): 27-45.

4. Atwood RJ. Parturitional posture and related birth behavior. Acta Obst GynecolScand. 1976; supl57:4-25

5. Nagahama EEI, Santiago SM. A institucionalização médica do parto no Brasil Ciência \&Saúde Coletiva. 2005; 10 93): 651-7.

6. Deslandes, SF; Ayres JRCM. Humanização e cuidado em saúde. Ciência \& Saúde Coletiva. 2005; 10(3): 510.

7. Ayres JR. Norma e formação: horizontes filosóficos para as práticas de avaliação no contexto da promoção da saúde. Ciência \&Saúde Coletiva. 2004. 9(3): 583-92.

8. Domingues RMSM, Santos EM, Leal MC. Aspectos da satisfação das mulheres com a assistência ao parto: contribuição para o debate.Cad. Saúde Pública. 2004; 20(1): 552-62.

9. Health Organization. 1995. Recommendations for Appropriate Technology following Birth. WHO Regional Office for Europe. Disponível em http://www.who.int /reproductive-health/publications.

10. American College of Obstetricians and Gynecologists:dystocia and augmentation of labor. Practice bulletin. N49. December 2003. Disponível em http:// www.acog.org 
11. Maria B; Dauptain G; Gaucherand P; Cohen H; Vige P; Berthet J et al. Accoucher et naître en France: propositions pour changer les naissances J Gynecol obstet Biol Reprod Biol. 2003; 32 (7): 606-16.

12. Serruya SJ, Lago TG, Cecatti JG. O panorama da atenção pré-natal no Brasil e o Programa de Humanização no Pré-natal e Nascimento. Rev. Bras. Saúde Matern. Infant. 2004; 4(3):269-79.

13. Hotimsky SN, Rattner D, Venâncio SI, Bógus CM, Miranda MM. O parto como eu vejo...ou como eu o desejo? Expectativas de gestantes, usuárias do SUS, acerca do parto e da assistência obstétrica. Cad. Saúde Pública. 2002;18(5): 1303-11.

14. Oliveira SMJV, Gonzalez Riesco ML, Rosas Miya CF. Tipo de parto: expectativas das mulheres. Rev. Latino-Am. Enfermagem. 2002; 10(5): $667-74$.

15. Tedesco RP, Maia Filho NL, Mathias L, Benez AL, Castro VCL, Bourroul GM, Reis Fl. Fatores determinantes para as expectativas de primigestas acerca da via de parto. RBGO. 2004; 26(10): 791-8.

16. Racinet C. Positions maternelles pour l'accouchement. Gynecol Obstet Fertil. 2005; 33 (7-8):533-8.

17. Green JM, Baston HÁ. Feeling in control during labor: concepts, correlates and consequences. Birth. 2003; 30(4): 235-47.

18. Spiby H, Slade P, Escott D,Henderson B, Fraser R. Selected coping strategies in labor: an investigation of womwen's experiences. Birth. 2003; 30 (3): 189-94

19. Carlson JM, Sachtleben - Murray M, Fenwick L. Maternal position during parturition in normal labor. Obstet Gynecol. 1986; 68(4): 443-7.

20. Stewart $P$, Calder AA. Posture in labour: patients'choice and its effect on performance. British J Obstet Gynaecol. 1984; 91: 1091-5.

21. Mamede FV.O efeito da deambulação na fase ativa do trabalho de parto (tese). Ribeirão Preto: Escola de Enfermagem de Ribeirão Preto; 2005.

22. Souza JP, Miquelutti MA, Cecatti JG, makuch MY. Maternal position during the first stage of labor: a systematic review. Reprod. Health. 2006; 3:10 
23. Cassol EGM, Canfield JT, Morais EN. Desempenho motor e emocional de Parturientes durante $02^{\circ}$ período do trabalho de parto: comportamento motor. Rev. bras. fisioter. 2001; 5(1): 9-16.

24. Polden M, Mantle J. Fisioterapia em obstetrícia e ginecologia. São Paulo. Santos. 1993.

25. Mauriceau F. Des maladies des femmes grosses et accouchés. Avec la bonne et veritable méthode de les bien aider en leurs accouchemens naturels. Am. J. Obstet Gynecol. 1979; 15(133): 455-6.

26. Johnson N, Johnson VA, Gupta J. Maternal positions during labor. Obst Gynecol Survey. 1991; 46 (7): 428-34.

27. Neme B. Obstetrícia. São Paulo: Sarvier. 2005. p. 134-8; p.167-8.

28. Caldeyro-Barcia R, Noriega-Guerral, Cibils L, Alvarez H, Poseiro J, Pose S. et al. Effects of position changes on intensity and frequency uterine contraction during the labor. Am J Obstet Gynecol. 1960; 80: 284-90.

29. Liu YC. Effects of an upright position during labor. Am J Nurs. 1974; 12: 2203-5.

30. Arroyo J, Menéndez C,Garcia-Ramos C, Izquierdo M, Lavilla J, Villa Elizaga J. et al. La position de pie durante el trabajo de parto espontáneo. Clin. Invest. Gin. Obst. 1974; 1: 221-31.

31. Mendez-Bauer C,Arroyo J,Garcia-Ramos C,Menéndez C,Lavilla J, Izquierdo $\mathrm{M}$ et al. Effects of standing position on spontaneous uterine contractility and other aspects of labor. J Perinat Med. 1975; 3: 89-100.

32. Roberts J, Mendez-Bauer C, Wodell DA. The effects of maternal position on uterine contractility and efficiency. Birth. 1983; 10: 243-9.

33. Leeuw - Harmsen L, Kock HCLV, Merkus JMWM. Observations on intra- uterine resting - phase pressure in at term pregnancy in different body positions. Eur J Obstet Gynecol Reprod Biol. 1983; 16: 83-8.

34. Mori HY, Chen SZ, Alsaka K, Matsuoka R, Kigawa T. The physiological role of the sitting parturient posture. Asia-Oceania $J$ Obstet Gynaecol. 1985; 11(1): 47-53.

35. Chen SZ, Alsaka K, Mori HY, Kigawa T. Effects of sitting position on uterine activity during labor. Obstet Gynecol. 1987; 69: 67-73. 
36. Roberts JE, Mendez-Bauer C, Blackwell J, Carpenter ME, Marchese T. Effects of lateral recumbency and sitting on the first stage of labor. J. Reprod. Med. 1984; 29:477-81

37. Mitre I. The influence of maternal position on duration of active phase of labor. Int J Gynecol Obstet. 1974; 12: 181-3.

38. Flynn A, Kelly J, Hollins G, Lynch P. Ambulation in labor. British Medical Journal. 1978; 26:591-3.

39. McManus T, Calder AA. Upright posture and the efficiency of labour. Lancet; 1978; 14: $72-74$.

40. Williams RM, Thom MH, Studd JW. A study of benefits and accepttibility of of ambulation in spontaneous labor. $\mathrm{Br} J$ Obstet Gynecol. 1980; 87:122-6.

41. Diáz AG, Schwarcz R, Fescina R, Caldeyro-Barcia R. Vertical position during the first stage of the course of labor and neonatal outcome. Eur.J Obstet Gynecol Reprod Biol. 1980; 11: 1-7.

42. Read JA, Miller FC, Paul RH. Randomized trial of ambulation versus oxytocin for labor enhancement: a preliminary report. Am. J. Obstet. Gynecol. 1981; 139: 669-72.

43. Hemminki E, Saarikoski S, Henriksson L. Ambulation versus oxytocin in protacted labour: a pilot study. Eur J Obstet Gynecol Reprod Biol. 1985; 20: 199-208.

44. Lupe PJ, Gross TL. Maternal upright posture and mobility in labor-a review.Obstet Gynecol. 1986; 67 (5):727-34.

45. Andrews CM, Chrzanowski M. Maternal position, labor and confort. Appl Nurs Res. 1990; 3;7-13.

46. Melzack R, Belanger E, Lacroix R. Labor pain: effect maternal position on front and back pain. J Pain Symptom Manage. 1991; 6: 476-80.

47. MacLennam AH, Crowther C, Derham R. Does the option to ambulate during spontaneous labour confer any advantage or disadvantage. J.Matern Fetal Med. 1994; 3(1):43-8.

48. World Health Organization. Care during the first stage of labour. In: Care in normal birth: a practical guide. Geneva. 1996. p. 20-4. 
49. Albers LL, Anderson D, Cragin L, Daniels SM, Hunter C, Sedler KD, et al. The relationship of ambulation in labor to operative delivery. $J$ Nurse Midwifery. 1997; 42:4-8.

50. Bloom S, Mclntire D, Kelly M, Beimer H, Burpor R, Garcia M et al. Lack of effect of walking on labor and delivery. N. England J Med. 1998; 339:76-9. 51. Goer H. Does walking enhance labor progress. Birth. 1999; 26(2): 127-9.

52. Kelly FN, Terry R, Naglieri R. A review of alternative birthing positions. J Am Osteopath Assoc. 1999; 99: 470-4.

53. Rooks JP. Evidence-based practice and its application to childbirth care for low risk women. J Nurse-Midwifery. 1999; 44 (5): 355-369.

54. Gupta JK, Nikodem C. Maternal posture in labour. Eur J Obstet Gynecol Reprod Biol. 2000; 92 (2): 273-7.

55. Walsh D. Why we should reject the "bed-birth" myth. British $J$ Midwifery. 2000; 8 (9): 554-8.

56. Vallejo M, Firestone L, Mandell G, Jaime F, Makishima S, Ramanathan S. Effect of epidural analgesia with ambulation on labor duration. Anesthesiology. 2001; 95:857-61.

57. Simkin P, O'Hara M. Nonpharmacologic relief of pain during labor: systematic review of five methods. Am J Obstet Gynecol. 2002; 186: 131-59.

58. Adachi K, Shimada, Usui A. The relationship between the parturient's and perceptions of labor pain intensity. Nursing Research. 2003; 52 (1):47-51.

59. Bodner-Adler $\mathrm{B}$, Bodner $\mathrm{K}$, Kimberger $\mathrm{O}$, Lozanov $\mathrm{P}$, Husslein $\mathrm{P}$, Mayerhofer K.Women's position during labour: influence on maternal and neonatal outcome. Wien Klin Wochenschr. 2003; 115 (19-20): 7203.

60. ACOG Practice Bulletin. Obstet Gynecol. 2003; 102(6):1445-54.

61. Frenea S, Chirossel C, Rodrigues R, Baguet JP, Racinet C, Payen JF. The effects of prolonged ambulation on labor with epidural analgesia. Anesth Analg. 2004; 98:224-9. 
62. Roberts CL, Algers CS, Olive E. Impact of first-stage ambulation on mode of Delivery among women with epidural analgesia. Aust N Z Obstet Gynaecol. 2004; 44 (6): 489-94.

63. Simkin $\mathrm{P}$, Bolding $\mathrm{A}$. Update on nonpharmacologic approaches to relieve labor pain and prevent suffering. J Midwifery Womens Health. 2004; 49(6): 489-504.

64. Lugina $H$, Mlay $R$, Smith $H$. Mobility and maternal position during childbirth in Tanzânia. BMC Pregnancy Chilbirth. 2004; 4: 3-12.

65. Cunningham FG et al. Dystocia - abnormal labor. In: Williams Obstetrics.22a ed. Mc Graw-Hill. N. York. 2005. p 501.

66. Cecatti JG, Calderón IMP. Intervenções benéficas durante o parto para a prevenção da mortalidade materna. Rev Bras Ginecol Obstet. 2005; 27(6):357-65.

67. Armitage $P$, Berry $G$. The planning of statistical investigations. In: Statical methods in medical research. $2^{a}$ ed. Oxford. Blachwell. 1987. p.179-85.

68. Philpott RH, Castle WM. Cervicographs in the manegement of labour in primigravidas. I The alert line for detecting abnormal labour. $J$ Obstet Gynecol Brit Com. 1972. 79: 592-8.

69. Godelieve DS. Cadeias Musculares e articulares. São Paulo. Summus. 2000.

70. Piret MM, Béziers M. A Coordenação motora. São Paulo. Summus. 1994.

71. Calais-Germain B. Le perinée feminine et l'accouchement. Paris. Ed. DésIris. 2000.

72. Balaskas J. Parto ativo. São Paulo. Ed Ground. 1993.

73. Kapandji A. Fisiologia articular. Tomo II. São Paulo. Roca. 1970.

74. Campignion P. Respir-action. Bruxelles. I.P.C la Gohelle. 1996.

75. Vieira S. Introdução à Bioestatística. $3^{a}$ ed. Rio de Janeiro.Campus. 1998. 
76. Soares JF, Siqueira AL. Introdução à Estatística Médica. Belo Horizonte. Depto Estatística UFMG. 1999.

77. Rosiska DO. Reengenharia do tempo. Rio de janeiro: Rocco,2005.

78. Bittar RE. Caesarean section rates skyrocket in Brazil.The Lancet. 2003;362:23

79. Pereira BG, Camargo MG, Couto EC, Amaral E, Passini JR, Parpinelli MA. Resultados Neonatais no Parto Vaginal espontâneo comparados aos do parto Com fórcipe de Simpson-Braum em primíparas. Rev Bras Ginecol Obstet. 2004; 26(1): 9-13.

80. laconelli $\mathrm{V}$. Maternidade e erotismo na modernidade: assepsia do impensável na cena de parto. Percurso. 2005; 34(1): 77-84.

81. Cury AF, Tedesco JJA. Aspectos polêmicos na indicação da cesariana. Femina. 2003; 31(9): 809-12.

82. Miquelutti MA, Cecatti JG, Makuch MY. Upright position during the first stage of labor: a randomized controlled trial. Acta Obstet Gynecol. 2007; 86: 553-8.

83. Françoso LO. Tipos posturais: variações anatômicas e seus efeitos sobre a gravidez. [ Dissertação].São Paulo. Faculdade de Saúde Pública da USP;2004

84. Simkin P. Maternal position and pelves revisited. Birth. 2003; 30(2): 130-2.

85. Spink MJ. O Conceito de representação social na abordagem psicossocial. Cad. Saúde Públ. 1993; 9 (3): 300-8.

86. Jodelet D. As representações sociais. São Paulo. Livraria Universitária. 2004.

87. Leite APL, Camano L, Souza E. Gravidez e sexualidade: crítica ao dogma cartesiano aplicado às questões sexuais da grávida. Femina.2007;35(6):399-401

88. Boltanski L. As classes sociais e o corpo. $4^{\mathrm{a}}$ ed. São Paulo. Ed. Paz e Terra. 2004. p.37-42; p.121-37; p.148-57. 
89. Armelin AR. Rotura prematura de membranas. In: Zugaib M, Bittar RE, editores Protocolos Assistenciais da Clínica Obstétrica da Faculdade de Medicina da USP. $2^{a}$ ed. São Paulo: Atheneu; 200p.328-33.

90. Albuquerque PB.O Partograma da gestante de baixo risco obstétrico.[dissertação] São Paulo. Faculdade de Medicina da USP. 1993.

91. Pain HHS. Marcas no corpo: gravidez e maternidade em grupos populares. In:Doença, Sofrimento, Perturbação: perspectivas etnográficas. L.F.D. Duarte \& O.F.Leal. org. Rio de Janeiro. Ed. Fiocruz. 1998. p 31-47.

92. Sabatino H, Serpa JF, Dias AL, Torresan RZ Sensação da contração uterina referida durante o trabalho de parto. J Bras Ginecol. 1996; 106 (11/12):429-34.

93. Bo K, Finckenhagen NB. Is there any difference in measurement of pelvic floor Muscle strength in supine and standing position? Acta Obstet Gynecol Scand. 2003; 82: 1120-4.

94. Anim-Somuah M, Smyth R, Howell C. Epidural versus non-epidural or no analgesia in labor. Update of Cochrane Database Syst Rev. 2003 (2):CD000331

95. Cortes CAF, sanchez CA, Oliveira AS, Sanchez FM. Analgesia de parto: estudo Comparativo entre anestesia combinada raquiperidural versus anestesia peridural contínua. Rev Bras Anestesiol. 2007; 57(1): 39-51.

96. Sabatino H, Braga FS, Pereira RR. Baixa dose em bloqueio peridural para trabalho de parto e parto. J Bras Ginecol. 1999; 109 (1/4):15-23.

97. Bruggemann OM, Parpinelli MA, Osis MJD. Evidências sobre o suporte durante o trabalho de parto/parto. Cad. Saúde Publ. 2005; 21(5): 131627.

98. Hodnet ED, Gates S, Hofmeyr GJ, Sakal C. Continuous support for women During childbirth. Cochrane Database Syst Rev. 2003; 93): CD 003766. 
99. Rodrigues AV. O suporte à parturiente: a dimensão no contexto da assistência ao parto. [dissertação]. São Paulo. Faculdade de Saúde Pública da USP. 2004.

100. Michel SC, Rake A, Treiber K, Seifert B, Chaoui R, Huch R. Obstetric pelvimetry: Effect of birthing position on pelvic bony dimensions. AJR. 2002; 179: 1063-7.

101. Rett MT, Simões JA, Herrmann V. Existe diferença na contratilidade da musculatura do assoalho pélvico feminino em diversas posições? ev Bras Ginecol Obstet. 2005; 27(1): 12-9. 